\title{
Seis años del pontificado malagueño de D. Esteban-José Pérez Martínez (1868-1874)
}

(La Iglesia en Málaga durante la Revolución de Septiembre del 68 y la $1 .{ }^{a} R e-$ pública)

En el consistorio celebrado en el Vaticano el 20 de junio de 1868, Su Santidad Pío IX, preconizaba para la diócesis de Málaga, vacante desde febrero de ese mismo año por fallecimiento del prelado D. Juan Nepomuceno Cascallana y Ordóñez, al titular de la silla de Coria-Cáceres, desde 1865, D. Esteban-José Pérez Martínez y Fernández.

La llegada de un nuevo obispo a una diócesis, como cualquier hecho similar de gobierno personal y'directo, aunque ensamblado en unas coordenadas fijas de actuación, en este caso, el Derecho Canónico, las orientaciones del Papa, las directrices de los dicasterios romanos y las normas emanadas de la archidiócesis de Granada, de la cual Málaga es diócesis sufragánea por la reestructuración llevada a cabo por el Concordato de 1851, es ocasión propicia para un análisis a fondo de la diócesis en cuestión de sus estamentos, de sus realizaciones, del personal..., es en definitiva señalar el «hic et nunc» de la Málaga religiosa, con sus inevitables connotaciones sociopolíticas, donde el nuevo prelado va a desarrollar su actividad apostólica como pastor supremo de la diócesis, en unos años cargados de densos acontecimientos políticos con claras incidencias en la vida religiosa de todas las actividades eclesiásticas.

\section{INTRODUCCIÓN}

\section{Estructura religiosa de la diócesis de Málaga}

1. División territorial

En el s. XIX la diócesis de Málaga pertenecía en lo civil a la provincia del mísmo nombre. Contaba con una extensión de $7.276 \mathrm{~km}^{2}$ en los que había 
135 parroquias enclavadas en 124 pueblos, de los cuales, 8 eran de la provincia de Cádiz y 1 de Granada. Dividida religiosamente en 13 arciprestazgos y judicialmente en 14 partidos; además le pertenecían en la costa africana los 3 presidios menores de Melilla, Alhucemas y el Peñón Vélez de la Gomera '.

El sistema orográfico divide a la provincia en cuatro regiones naturales de características muy distintas: Serranía de Ronda, Zona de Antequera, Hoya de Málaga y la Axarquía-Vegas Litorales. Estas características geográficas eran condicionantes reales para una estructuración de la diócesis y la compleja solución a la hora de intentar una acción pastoral adecuada que se debe basar, para ser eficaz, en criterios de agrupar tipos humanos, geografía, economía, paisaje, producción y ocupación de idénticas características.

Era deber y competencia del obispo dividir su territorio en regiones, distritos o zonas compuestas por varias parroquias que se llaman vicariatos foráneos, decanatos o arciprestazgos.

Basados en motivos de extensión geográfica se hacían muchas veces divisiones arbitrarias y problemáticas para la coordinación religiosa y pastoral. Mientras que el arciprestazgo de Olvera tiene 2 pueblos, o el de Coín, 4, al de Vélez-Málaga le corresponden 15, y 14 al de Ronda ${ }^{2}$.

\section{Parroquias, clero y fieles}

Contando la provincia de Málaga en 1768 con un censo de 244.882 habitantes, 96 pueblos y 111 parroquias ${ }^{3}$, tres cuartos de siglos después su censo ha aumentado 93.620 habitantes, 17 pueblos y 33 parroquias, respectivamente.

Según las estadísticas de 1860, la diócesis de Málaga cuenta con 454.793 almas y 134 parroquias ${ }^{4}$.

El clero en esta diócesis está formado en 1768 por 1314 miembros, de los cuales, sólo un $8,4 \%$ están dedicados a la cura de almas, correspondiendo 2.205 almas por sacerdote 5 . Tres cuartos de siglo después tiene 313 sacerdotes seculares dedicados directamente a la cura de almas y le corresponden a cada uno $1.081,2$ fieles ${ }^{6}$.

En las estadísticas eclesiásticas había una serie de personas a las que se de-

1. Guía Eclesiástica de España, 1860, 494 y 882; 1865, 377; 1868, 269. En adelante citaremos G.E.E.

2. Boletín Eclesiástico del Obispado de Málaga, 21-X-1877, 160-163. En adelante citaremos B.E.O.M. G.E.E., 1860, 487; 1865, 374; 1868, 265.

3. SÁEz MARín, J., Datos sobre la Iglesia española contemporánea (1768-1868). Ed. Nacional.- Madrid 1975, 94.

4. G.E.E., $1860,883$.

5. Sáez Marín, J., Datos..., o.c., 288 y 291.

6. Ibid., 332 . 
nominaba "adscrito" - varones y hembras-y eran todas aquellas, que sin haber profesado en religión ni estar ordenadas, vivían de, para o junto a la Iglesia, sin ninguna función específica. Es un vestigio residual, pero significante, que arrastra España como legado testamentario del Antiguo Régimen. Según el censo de 1768, en la diócesis de Málaga existen 1.677 adscritos ?

El Cabildo de la catedral, según el arreglo propuesto por el Concordato de 1851 , había quedado reducido a 36 miembros, distribuidos de la siguiente forma:

-20 capitulares: 5 dignidades (Deán, Arcipreste, Arcediano, Chantre y Maestrescuela) y 15 Canónigos.

-16 Beneficiados ${ }^{8}$.

La edad media de los miembros del cabildo es de 55,6 años. De la diócesis y provincia de Málaga proceden 15 miembros, 5 de Granada, 3 de Valencia y Córdoba, 2 de Sevilla y 1 de Toledo, Sigüenza, Palencia, Baza, Lugo, Tortosa, Cartagena-Murcia y Segovia. Título académico tienen 16: 6 son doctores, 6 licenciados y 4 poseen los de doctor y licenciado. Por último llevan un promedio de servicio en la diócesis de 8,6 años ${ }^{9}$.

\section{Presupuesto de culto y clero}

Según lo previsto en el Concordato, el Real Decreto de 30-IV-1852 y la Real Orden de 18-X-1852 y disposiciones particulares se había llevado a cabo una profunda reestructuración del clero y del presupuesto. Para la diócesis malagueña, la asignación correspondiente al año 1854 es de 2.806 .891 reales ${ }^{10}$. Las fluctuaciones anuales que se aprecian corresponden al número de defunciones de los miembros de las colegiatas que se suprimieron, según el Concordato, y que eran cargos a extinguir y al crecimiento vegetativo del clero. Los presupuestos para 1860 es de 2.741 .798 y para 1868 es de 2.715 .196 reales respectivamente ".

En carta confidencial, dirigida al Vicario Capitular de Málaga el 29-VIII1868 por el Ministro de Gracia y Justicia del último gobierno de Isabel II, Carlos M. ${ }^{a}$ Coronado, le exponía la penuria en que continuaba el Tesoro público, por el déficit económico de años precedentes agravado por la imposibilidad de cobrar las contribuciones en las provincias y las malas o nulas cosechas. El Estado se compromete a reducir los gastos públicos y grava a los empleados suyos con un descuento del $5 \%$ para enjugar la situación. La me-

7. Ibid., 364.

8. G.E.E., 1860, 483-84; 1862, 372-373; 1865, 370-371; 1868, 262-263.

9. Archivo Catedral de Málaga, leg. 686, sin numerar. En adelante citaremos Arch. C.M.

10. VArios, Diccionario de Historia Eclesiástica de España. Dirigido por Q. Aldea, T. Marín y J. Vives. C.S.I.C.- Madrid 1972-75.- t. III, 1901.

11. G.E.E., 1860, 492-493; 1868, 268. 
dida no es suficiente y el gobierno recurre al clero, «confiando en este noble y patriótico comportamiento, esperando sigan el descuento voluntario ofrecido el año anterior» ${ }^{12}$. El Ministro reconoce las irregularidades económicas que el gobierno ha tenido con el dinero y destino del presupuesto eclesiástico: «debo francamente confesar que en el último año no siempre han estado satisfechas las obligaciones eclesiásticas con la debida preferencia» ${ }^{13}$. Termina la carta invocando el tema que la había motivado: «excite la piedad del clero para que durante el próximo año económico de 1868-69 ofrezca nuevamente de su espontánea voluntad al Estado el importe del $5 \%$ de sus dotaciones» ${ }^{14}$. Málaga aportaba $135.759,8$ reales.

\section{Seminario}

El edificio del seminario estaba anejo al palacio episcopal ${ }^{15}$. Ante la noticia de que el Ayuntamiento pretende derribarlo con fines de mejoras urbanísticas, el obispo Cascallana acude al gobierno para que por acuerdo concordatario se le cediera a la mitra el ex-convento de S. Agustín y fuese a la vez como una compensación por el edificio que se pensaba derribar. El Nuncio en Madrid, Lorenzo Barili, apoyaba la petición.

Por tres RR.OO. de 17-VI-1861, 24-V-1862, 24-V y 7-VII de 1862 se concede al prelado el derecho de propiedad sobre el citado ex-convento. El $28-\mathrm{V}$ 1863 se hace la escritura de cesión al seminario y por R.O. del Ministerio de Gracia y Justicia de 7-VIII-1863, S.M. se sirvió «prestar su soberana aprobación a la referida escritura de traslación perpetua del pleno dominio del edificio que fue convento de S. Agustín» ${ }^{16}$.

Después de unas notables obras de reparación y adaptación a los fines que a partir de ahora se le iba a dedicar, y cuyo importe ascendió a 100.000 pts., el 25-X-1863 se abre el edificio como seminario menor, aunque pasaron a él también los alumnos de filosofía. Todavía al finalizar el sexenio, volveremos a encontrarnos con el tema, siempre polémico, de la legítima propiedad del edificio.

Monseñor Cascallana se aplica a una profunda reforma académica, disciplinar, moral y formativa de toda la estructura del seminario. Crea el cargo

12. Arch. C.M., leg. 686, sin numerar.

13. Ibid.

14. Ibid.

15. El seminario conciliar de San Sebastián funcionaba con dos secciones: Mayor (teología, filosofía y cánones) y Menor (humanidades). El edificio del seminario mayor era el que estaba anejo y aún tomaba algunas dependencias del palacio episcopal. Se trasladó a este edificio para destinar el primitivo edificio del seminario malagueño - el viejo colegio de Seises- a seminario menor. Cf. Valle Zamudio, M., Apuntes históricos del seminario de Málaga. E. Salesiana, Málaga $1928,140$.

16. Valle Zamudio, M., Apuntes..., o.c., 138. 
de Regente de estudios, suprime la salida a sus respectivas casas y pueblos durante las vacaciones de Navidad y Semana Santa, ya que en los pueblos hay poco que aprender de piedad y convivencia caritativa, se hace un nuevo plan de clases y academias acomodándose a lo dispuesto después del Concordato y redactó - curso $1859-60$ - un reglamento para seminaristas externos ${ }^{17}$.

La reforma espiritual se basaba en la creación de dos congregaciones en honor del Santísimo Sacramento y la Inmaculada para los ordenados in sacris y el resto de los seminaristas, respectivamente. Se intensificaron las prácticas espirituales, misa diaria y frecuencia de sacramentos. La oración mental, la lectura espiritual y el examen eran tres momentos al día - mañana, tarde y noche-- que acrisolaban el espíritu del candidato al sacerdocio.

El plan de estudios de los seminarios conciliares españoles, por R.O. de 10-IX-1866, había sido incorporado a las universidades del reino con reconocimiento civil de los estudios en ellos realizados ${ }^{18}$. En el seminario de Málaga cursan estudios el año 1860, 370 alumnos; aumenta a 434 en 1865, y a 559 en 1867. Los profesores son 8 , en $1860 ; 12$, en 1865 y 67 . Para mantenimiento y gastos percibe una dotación del Estado que asciende a 90.000 reales ${ }^{19}$.

\section{Clero regular}

En estos años aún se sienten los efectos de los vaivenes reformistas y las leyes desamortizadoras de años atrás. Para todo lo relacionado con la exclaustración - causas, desarrollo y consecuencias- de los religiosos en España, véase el estudio de Revuelta ${ }^{20}$. Muchos religiosos se secularizaron y otros se incorporaron a las parroquias de la diócesis; los exclaustrados de Málaga que se incorporan y adscriben a parroquias son: 1860,$245 ; 1862,269$; 1865,$323 ; 1868,677^{21}$. El número de los religiosos exclaustrados sin cargo en la diócesis de Málaga es: 1860,$129 ; 1865,92 ; 1868,106^{22}$.

Entre los exclaustrados hay que distinguir tres grupos:

1) Los incorporados a cargos y tareas eclesiásticas de las diócesis. Por este motivo ya no se les considera como exclaustrados, sino que pasan a formar parte del clero secular diocesano.

2) Los exclaustrados que no poseen cargo ninguno ni están adscritos a

17. Ibid., 137 .

18. Ibid., 139. Con la revolución del 68 y la declaración de libertad de enseñanza, el seminario quedó desligado de la universidad de Granada y sin reconocimiento civil los estudios en él realizados. Cf. Ibid., 140.

19. G.E.E., $1860,488-489 ; 1865,374-375 ; 1868,267$

20. Revuelta GonZÁlez, M., La exclaustración (1833-1840). B.A.C.- Madrid 1976.- 503 págs.

21. G.E.E., 1860, 934-935; 1862, 647; 1865, 659; 1868, 683.

22. Sáez Marín, J., Datos.., o.c., 458. 
parroquias o servicio eclesiástico alguno y que sólo están incardinados en las diócesis a afectos de percibir alguna pensión.

3) Los adscritos al servicio de las parroquias que no disfrutan de emolumentos fijos procedentes del capítulo de culto y clero secular, pese a su adscripción, siguen figurando como exclaustrados entre los miembros de las clases pasivas.

El número de conventos de religiosos en la diócesis de Málaga es de $20 \mathrm{y}$ están ubicados de la siguiente forma: 8 en la capital, 6 en Antequera, 3 en Ronda, 2 en Vélez-Málaga y 1 en Archidona ${ }^{23}$. En el censo de 1859 se da el total de 216 religiosas y 463 en el de $1867{ }^{24}$. No todas las religiosas exclaustradas percibían pensión del Estado. En Málaga la perciben, según el censo de 1859, $14 ; 1864,12$ y $1867,9^{25}$.

\section{Ambiente religioso}

La masa del pueblo a nivel diocesano permanecía fiel y firmemente unida a la opinión, sugerencias y directrices de su prelado y a sus creencias tradicionales. Esta religiosidad popular se vertía en los moldes tradicionales de su peculiar idiosincrasia: peregrinaciones, cultos devocionales o sacramentales, procesiones, romerías... Arraigado en su fe superficial, pero válida, porque les mantenía religados a Dios, aunque no por los cauces legítimos, el pueblo había llegado a una práctica rutinaria, y, en no pocos casos fetichista.

En la segunda mitad del s. XIX Málaga vibró en las dos visitas - una inesperada, otra intencionada - del prelado protagonista de la orientación de política-religiosa de la Reina en los decenios centrales del siglo: Antonio M. ${ }^{a}$ Claret ${ }^{26}$.

El 15-I-1851 cuando el arzobispo de Trajanópolis se dirigía a Cuba a tomar posesión de su nuevo destino, una pertinaz borrasca y fuerte temporal en el Estrecho hizo que el barco - «La nueva Teresa Cubana»- volviese al puerto malagueño a esperar la calma y mejores vientos. Coincidió con la celebración en la capital de unas misiones, dirigidas por el capuchino Félix $\mathrm{M}^{\mathrm{a}}{ }^{\mathrm{d}} \mathrm{de}$ Arriete y Llanos ${ }^{27}$. Su estancia fue de tres días en que permaneció como huésped de honor del prelado, cabildo y pueblo católico de Málaga ${ }^{28}$. Afirma Claret de esos días: «Me buscaron ocupación y prediqué quince sermones en la

23. G.E.E., $1860,490-491$;

24. G.E.E., 1860, 950-951; $1868,688$.

25. G.E.E., $1860,964-965 ; 1865,666-667 ; 1868,690-691$.

26. Gutiérrez Serrano, F., San Antonio M. ${ }^{a}$ Claret en Málaga. Coculsa.- Madrid 1974.184 pág.

27. Posteriormente sería propuesto para suceder a S. Antonio M. ${ }^{\text {a }}$ Claret en el arzobispado de Cuba y finalmente nombrado obispo de Cádiz, del que le pretenderán sacar para la silla de Valencia, en los días de la I República, y a la que renunció antes de la promoción.

28. Arch. C.M., Actas Capitulares, t. 66, 16-I-1851. En adelante citaremos A.C. 
catedral, seminario, a los estudiantes y a los conventos» ${ }^{29}$. Por esta oportunidad y por el fruto obtenido, «la venida a esta ciudad creo que fue una grande disposición de Dios para el bien de aquella ciudad» ${ }^{30}$. Con un recuerdo imperecedero según el efecto conseguido y las crónicas, el arzobispo partió de Málaga la madrugada del 19-I ${ }^{31}$. El mismo arzobispo, pocos días después desde Canarias, resumía así su experiencia: «Los malagueños han quedado muy contentos de mí y yo también de ellos ${ }^{32}$.

La segunda visita de Claret a Málaga se inscribe dentro del viaje que Isabel II realiza por Andalucía en otoño de 1862 . Son momentos aún tensos porque el recuerdo y la consecuencia de los sucesos de Loja estaban demasiado recientes. Así lo ve el prelado: «De algunos años a esta parte ha habido mucha apatía, tanto de parte de los gobernantes como de parte de los eclesiásticos, y los socialistas y los protestantes han sabido aprovechar bien la ocasión. Mientras los unos han dormido los otros han sembrado la cizaña en aquel hermoso campo» ${ }^{33}$.

Del viaje por tierras andaluzas, a Málaga le correspondió los días 16 al 19 de octubre. Nuevamente entre los actos oficiales a los que tiene que asistir con la Reina, al F. Claret le queda tiempo para repetir la anterior experiencia. Ahora son dieciséis sermones ${ }^{34}$. Al llegar a Madrid hace balance: «hubo grandes conversiones, aunque no se confesaron conmigo por falta de tiempo, pero me lo han escrito los mismos penitentes convertidos» ${ }^{35}$.

\section{El Obispo D. Esteban-José Pérez Martínez y Fernández}

\section{Datos Biográficos ${ }^{36}$}

D. Esteban-José Pérez Martínez nació en Jorairatar (Granada) el 24-IX-

29. Gutiérrez Serrano, F., San Antonio..., o.c., 45.

30. Ibid., 41-42.

31. «El Avisador Malagueño» recogió fiel y cumplidamente la estancia y actividad del P. Claret en Málaga. Cf. días 16, 17, 18, 21 y 28 de Enero de 1851.

32. Gutierrez Serrano, F., San Antonio..., o.c., 69.

33. SAn ANTONIO María ClaRET, Escritos autobiográficos y espirituales. B.A.C.- Madrid $1959,390$.

34. Gutiérrez Serrano, San Antonio..., o.c., 113.

35. San Antonio María Claret, Escritos..., o.c., 386.

36. Por carecer de una biografía y de estudjos documentados acerca de este obispo, nos vemos precisados a rastrear algunos datos en lugares difíciles, inaccesibles y casi inadecuados; de ahí que puedan resultar imprecisos, muchas veces e incompletos, otras. También hay que tener presente que los saqueos e incendios que ha sufrido el palacio episcopal de Málaga y su archivo han traído consigo el que desaparezcan para siempre una serie de documentos que hacen y harán más difícil la reconstrucción basada en documentos, de la historia eclesiástica - y en parte civilde Málaga.

Cf. Archivo Narciso Díaz de Escovar, leg. 192, carp., 2. En adelante citaremos Arch. N.D. de E. Cuenca ToRiBio, J.M., Sociología de una élite de poder de España e Hispanoamérica con- 
$1799{ }^{37}$. Séptimo hijo de padres con una posición desahogada, dedicados a las tareas campesinas ${ }^{38}$.

Terminada la guerra de la Independencia, ingresa en el seminario de S. Cecilio de Granada cursando allí toda la carrera eclesiástica. Es ordenado sacerdote en 1824; demuestra afición al estudio y continúa hasta obtener los títulos de Bachiller y Maestro en Artes; posteriormente, en 1825, se gradúa en Bachiller y Doctor en Teología por la universidad de Granada ${ }^{39}$. Acepta una cátedra de teología en el seminario de Granada y De Vera Religione en la universidad.

La agitación intelectual de los primeros años de la década ominosa del reinado de Fernando VII viene a soliviantar demasiado la universidad y a convertirla en algo más que en un lugar de trasvase de saberes, que era como nuestro futuro obispo entendía la misión del profesor, y la universidad, como el lugar donde más y mejor se podía realizar este ideal. Abandona la misión docente-intelectual y escoge la actividad pastoral en parroquias, tomando parte en las oposiciones a curatos y obteniendo en propiedad la de San Gabriel de Loja.

En 1826 hace oposiciones a la canongía magistral de Málaga y obtiene el segundo puesto. Reconociendo el éxito en sus disertaciones teológicas y en

temporánea: la jerarquía eclesiástica (1789-1965). Ed. Escudero.- Córdoba 1976, 381 págs. Ibid. El episcopado español en el pontificado de Pío IX, I: apunte sociológico. Universidad de Valencia 1974.- 148 págs. (El texto de este estudio forma la parte central del primero, por eso para las citas sólo indicaremos el de Sociología...). LLORDEN, A., Episcopologio malagueño (inédito) págs. 572-586. B.E.O.M., passim (años 1868-1878).

37. Es un miembro más del elemento rural del que provienen la mayoría de obispos españoles en el período 1846-1877 y algo llamativo en la región Sur, donde se concentran un buen número de obispos provenientes de ámbito ciudadano. CuenCa Toribio, J.M., El episcopado..., o.c., 125.

38. «No hubo, pues casta sacerdotal, y el estamento estuvo siempre abierto a todos. De hecho, no fueron pocos los que desde las posiciones más humildes ascendieron a las más elevadas».; Dominguez OrTiz, A., Las clases privilegiadas en la España del Antiguo Régimen. Madrid 1970, 23.

39. Según el análisis que hace Cuenca Toribio de los centros y la formación de los obispos en este período, tenemos:

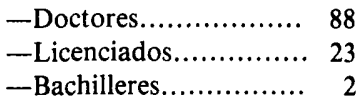

Sociología..., o.c., 136. Sin embargo, creemos que el número total de graduados hace un poco cruel el comentario del mismo Cuenca cuando afirma que «el adocenamiento distinguió a los obispos de este pontificado por motivo de la postración casi total de las instituciones educativas eclesiales», o.c., 39. MARTIN HERnÁNDEZ, F., Un seminario pretridentino. El Real Colegio de San Cecilio de Granada (1492-1842). Universidad de Valladolid, Cuaderno de H. ${ }^{\text {a }}$ Moderna, n. ${ }^{\circ}$ 18.-1960.- 160 pág. 
Sagrada Escritura, le conceden en 1827 el título de examinador sinodal para la diócesis de Málaga y en 1837 para la de Córdoba.

En 1837 es elegido diputado provincial por Loja y su partido y convencido de que podía servir a esta vocación y a la Iglesia desde este puesto tan problemático, supo aunar criterios y demostrar capacidad negociadora en los difíciles momentos por los que pasó la ciudad de Motril en 1838 cuando la subversión parecía que había acampado allí. Comisionado por el jefe superior político, reconcilió los agitados ánimos de un vecindario profundamente dividido, receloso y hostil en llegar a un acuerdo. La junta revolucionaria de Granada le priva en 1840 de su cargo de diputado y no será repuesto hasta 1844 .

En 1847 se le nombra predicador de la Real Capilla y en 1850 el arzobispo de Toledo y Cardenal Primado, Bonel y Orbe, le hace canónigo de su catedral. En 1857 se le concede el de arcediano de la catedral de Granada ${ }^{40}$. En 1865 es presentado por el Gobierno español ${ }^{41}$ y preconizado por Pío IX para el obispado de Coria-Cáceres ${ }^{42}$ y en el consistorio secreto del 20 -VI-1868 para la sede malagueña ${ }^{43}$. El 16-I-1874/fue presentado y. preconizado arzobispo de

40. Nuestro obispo confirma y contradice la regla: la contradice, porque tenía larga experiencia de la vida parroquial y la confirma, porque los miembros de los cabildos catedrales y seminarios son los que nutren las ternas de las que salen casi todos los obispos de esta época. Cf. Cuenca Toribio, J.M., Sociología..., o.c., 143-149.

41. Dado el carácter secreto y confidenćial que se daba a la selección de posibles candidatos -entre los obispos, la nunciatura y las altas personalidades del poder civil- es arriesgado reconstruir los pasos dados en estas situaciones. Sin embargo, poseemos el expediente de nuestro obispo y los móviles que tuvieron presente en su designación. «Excmo. Sr.: Por R.O. de 25 de abril último, recordada por otra del 21 del pasado, se sirvió S.M. mandar informarse esta Regencia cuanto se le ofrezca y parezca de la conducta moral y política de D. Esteban-José Pérez, canónigo de la Sta. Iglesia Primada de Toledo. Para cumplir con este mandato acordé pedir informes al Gobernador de la provincia y Juez de Primera Instancia de aquella ciudad, y el primero me manifiesta que de los datos y antecedentes que obraban en sus oficinas, resulta que la conducta moral del interesado es buena, sin dejar nada que desear por ser intachable a la vez que ilustrado y virtuoso; pero la política es en sentido contrario por la amistad que le liga con el general Narváez y por su conformidad con la política de resistencia seguida por aquél, a cuya influencia con el diocesano debe el canonicato que obtiene: que esta circunstancia y la de haber expresado últimamente, como quien tiene probabilidades de certeza, que no pasarán 15 dias sin que desaparezca de la escena pública los hombres y la situación actual, manifiestan de una manera indudable, no sólo no hallarse identificado con la situación actual, sino ser contrario a ella. El juez se limita a decir que la conducta moral es irreprensible y la política altamente desafecta al actual orden de cosas». Que es cuanto puedo informar en cumplimiento de lo mandado. Dios guarde a $\mathrm{Vd}$. muchos años. Madrid, 1 de junio de 1855. Excmo. Sr.» (Ministro de Gracia y Justicia). Archivo del Ministerio de Justicia, leg. $3493, \mathrm{n} .{ }^{\circ} 11.288$.

42. Según el estudio estadístico de Cuenca, Sociología..., o.c., 115, la edad media de los obispos en el momento de las preconizaciones es de 54 años D. Esteban-José tenía en esos momentos 66 años.

43. En los traslados de diócesis no se tenía en cuenta factores religiosos o pastorales y sí aspectos puramente temporales, lo que explica con visos de probabilidad la dependencia de la Iglesia de los intereses del Estado. Además, se clasificaban las diócesis de entrada, ascenso y culmina- 
Tarragona, dignidad a la que renunció, siendo nuevamente confirmado como obispo de Málaga.

Transcurrió su vida con una salud débil y delicada que solía reponer con reposo y cambios de aire en su «país natal», como él decía o en Loja, donde tantos y tan buenos amigos había hecho durante su estancia de párroco. Unas fiebres comatosas se complicaron en pocas horas y en la madrugada del 27-X1878 moría en Málaga ${ }^{44}$. Estaba en posesión de los títulos de Caballero Comendador de las Órdenes de Carlos III y de Isabel la Católica, de la Cruz de Isabel la Católica, Prelado Doméstico de Su Santidad y Asistente al solio pontificio.

\section{Primeros contactos con Málaga}

Desde los ya lejanos días en que había sido examinador sinodal, es ahora en 1868 cuando vuelve a tener contacto con la capital andaluza. El 2-VII-1868 el deán D. Diego de La Chica comunica al cabildo que ha recibido un oficio del obispado de Coria-Cáceres en el que le anuncia haber sido preconizado por Pío IX para la Silla y Obispado de Málaga ${ }^{45}$. En esa misma sesión el cabildo decide contestar ofreciéndose «a cooperar a todos y cada uno de los actos y resoluciones que la prudencia de V.E.I. le dicte para bien de esta diócesis. Nada más lisonjero al cabildo que la estrecha unión con su dignísimo prelado» ${ }^{46}$.

El otoño se anuncia caliente y la realidad supera a todas las previsiones. Demasiados acontecimientos y demasiado urgentes para atender la burocracia rutinaria de la Administración. Hasta el mes de diciembre no recibe el visto bueno por parte del Gobierno para dar los últimos pasos previos a la entrada e incorporación a su nueva diócesis. El 15 de ese mes recibe del Gobierno Provisional el «exequatur» a las Bulas Pontificias en virtud del derecho de patronato ${ }^{47}$. Aprovecha su estancia en Loja para reponerse y entrar en la nueva diócesis. Ese mismo día remite la noticia a Málaga, las Bulas y las Ejecutorias y los poderes a favor del deán para que tome posesión en su nombre

ción, y no pocas veces muchos cambios y ascensos provenían para premiar servicios, adhesiones e intereses siempre ajenos a las necesidades pastorales de las diócésis. Cf. CuENCA TORibio, J.M., Sociología..., o.c., 165-174.

44. Según el estudio estadístico de Cuenca, Sociología..., o.c., 117-120, la duración media de los pontificados en este período es de 14 años. D. Esteban-José fue obispo durante 13 años; la edad media de defunción era de 69 años y la de nuestro obispo fue de 79 .

45. «Grata nos ha sido la noticia de la traslación a un país tan cerca del cielo que vimos al nacer, del primer suelo que pisamos, en el que hemos pasado nuestra vida». Arch. C.M., A.C., t. 70, 2-VIII-1868.

46. Arch. C.M., Minuta de Cartas, t. 16, 3-VII-1868. En adelante citaremos M.C.; A.C., t. 70, 3-VII-1868.

47. Arch. C.M., leg. 686, sin numerar. 
de la sede malagueña; también envía una comunicación para que sea abierta y leída ante el cabildo una vez que D. Diego de La Chica haya tomado la posesión ${ }^{48}$.

En la sesión capitular del 18 el deán anuncia que se han recibido todos los documentos ${ }^{49}$ y se nombra una comisión para la revisión de los mismos ${ }^{50}$. Se le contesta que han llegado los documentos y se deja entrever el deseo de que su presencia sea efectiva ${ }^{51}$. El 20 de diciembre la comisión capitular emite dictamen favorable por "no hallar reparo alguno" en las Bulas y en las Ejecutorias ${ }^{52}$ y se señala el próximo día 23 para la toma de posesión ${ }^{53}$.

El día 21 el alcalde de la ciudad, D. Pedro Gómez remite un oficio al cabildo acusando recibo de la invitación a la toma de posesión, pero excusándose porque ese día «tiene que presidir el excrutínio de votos para el nombramiento de concejales» ${ }^{54}$. La víspera de la toma de posesión el lectoral $\mathrm{D}$. Vicente Tudela hace público el certificado de la Bula dirigida al pueblo y fieles de la ciudad y diócesis ${ }^{55}$.

48. Ibid.

49. El conjunto de documentos expedidos en Roma, el 22-VI-1868, está compuesto por:

1) Absolución de censuras.

2) Presentación para la silla y episcopado de Málaga y traslación de la de Coria-Cáceres.

3) Bula dirigida al Metropolitano de Granada, de la que Málaga es diócesis sufragánea.

4) Bula dirigida a la Reina.

5) Bula dirigida al cabildo de Málaga para que le dé posesión.

6) Bula al clero de la diócesis malagueña.

7) Bula al pueblo y fieles de la diócesis para que le presten obediencia.

8) Bula de vasallos.

9) Bula a cualquier obispo católico para la recepción del juramento. Arch. C.M., A.C., t. 70, 18-XII-1868. En la misma sesión se retienen en la forma ordinaria las bulas dirigidas a la Reina, por las circunstancias políticas de todos conocidas, y la de vasallos por no ser propia de la potestad eclesiástica. Ibid.

50. La comisión estaba formada por los Sres. capitulares: D. Juan Nepomuceno López, D. Vicente Tudela y D. José Moreno, Magistral, Lectoral y Penitenciario, respectivamente. Arch. C.M., A.C., t. 70, 18-XII-1868.

51. «Esta corporación se complace de que sea llegada la hora de tener a su frente a un Padre y Pastor tan digno, y por lo mismo procederá inmediatamente a cumplir las órdenes de V.E.I». Arch. C.M., M.C., t. 16, 19-XII-1868.

52. En estas Ejecutorias, dadas en Madrid el 20 de noviembre, se resuelve que el juramento que ha de hacer el obispo a la Sta. Sede «sea y se entienda sin perjuicio del debido a la Potestad Soberana de la Nación» Arch. C.M., A.C., t. 70, 18-XII-1868. El nuevo Gobierno nacido de una revolución liberal, con claro matiz anticatólico por la legislación que por esas fechas ya había hecho pública y librecultista, sin embargo, no renuncia a los privilegios del régimen anterior, dándose cuenta de que tiene en sus manos un arma poderosa de control de una fuerza nada despreciable, como era la Iglesia católica, y, en concreto, su jerarquía.

53. Arch. C.M., leg. 686, sin numerar.

54. Ibid.

55. Concuerda con el original latino, dado en Roma, el 22-VI-1868. Málaga, 22-XII-1868. Arch. N.D. de E., leg. 192, carp. 2,5. 


\section{Toma de posesión}

A las 11 de la mañana del día 23 de diciembre se celebró el acto de toma de posesión por poderes. Inmediatamente después se dio lectura al pliego enviado el día 15 para esta ocasión que contiene los primeros nombramientos, que son una confirmación de todos. Firman como testigos del acto los nueve párrocos de la capital y enviando un oficio a las superioras religiosas y párrocos de la diócesis comunicando la toma de posesión del nuevo obispo ${ }^{56}$. Al día siguiente el cabildo se apresura a relatar por escrito los detalles de la ceremonia a su nuevo obispo, al que le envían una triple felicitación: por la toma de posesión, por Navidad y por su onomástica ${ }^{57}$.

El 16-II-1869, cuando ya toda la ciudad se ha tranquilizado de los violentos acontecimientos con que despidió el año viejo y recibió al nuevo, el obispo escribe desde Loja anunciando su llegada para el día 20. El primer acto con el que va a entrar en contacto con sus diocesanos será repartir 1.500 reales en metálico y 1.200 panes de dos libras entre las familias de los muertos, heridos y pobres en general ${ }^{58}$. El día 23 , a las cuatro de la tarde, es la entrada pública en la forma acostumbrada ${ }^{59}$. La ceremonia es breve y sencilla; todo gira en torno al discurso que el nuevo prelado dirige a las autoridades, cabildo, clero y pueblo asistente al acto.

Comienza reconociendo su falta de méritos para llenar el vacío dejado por su predecesor y se detiene ampliamente en el tema de la paz, tan debilitada en Málaga en esas últimas semanas y en general en España, para pasar después a la concordia humana, a la comunión de espíritus que es la caridad cristiana. «Dichosos si al fin hemos enjugado las lágrimas de los desgraciados y sanado las heridas que abrieron las pasiones... dichoso si al fin os podemos dejar la unión y la paz; la paz de Cristo, la paz del corazón que es fruto de la caridad» ${ }^{60}$. Y esto sólo se puede lograr cuando estamos a bien con nuestra conciencia y no nos acusa de nada. "Queremos para vosotros la paz de una buena conciencia» ${ }^{61}$. La meta es clara; el camino, difícil y exigente, pero Cristo lo ha marcado y nos ha dejado a la Iglesia con inmensos beneficios para nuestra ayuda, ya que «la Iglesia ha elevado a la criatura y ha unido al hombre con Dios y a los hombres con los hombres; es lazo de orden social, reparadora de las miserias humanas; sana las dolencias de los corazones que sufren y da la paz a los afligidos» ${ }^{62}$. El hombre no puede olvidar la realidad de la lucha que es la vida y somos como atletas que nos ejercitamos bajo la mirada de Dios. Cuando lo material, el egoísmo y nuestra razón son los criterios últimos de

56. Arch. C.M., leg. 686, sin numerar.

57. Arch. C.M., M.C., t. 16, 24-XII-1868.

58. B.E.O.M., 20-II-1869, 30.

59. Arch. C.M., A.C., t. 70, 21-II-1869.

$60,61,62$ y 63 у B.E.O.M., 28-II-1869, 37-43. 
nuestro vivir, obrar y sentir, no hay salvación para ese hombre y para la sociedad donde vive, trabaja y de la que es miembro. «No sólo de pan vive el hombre sino que necesitamos la palabra que sale de Dios (Mt. 4,4). Mientras que el hombre sólo reconozca por tribunal de sus creencias la débil razón y su menguada inteligencia sea el solo criterio de sus ideas, no hay salvación para el hombre y la sociedad» ${ }^{63}$.

\section{Pastoral programática}

Pocos días después de su incorporación de facto a la diócesis, aparece publicada en el Boletín del Obispado la primera carta pastoral. Allí se articulan, más una serie de principios teóricos y doctrinales que orientaciones para la práctica pastoral. Es una declaración doctrinal con visos de modernidad por el enfoque de ciertos principios prácticos, pero salvaguardando la autoridad del obispo, asistido por el cabildo y ayudado por los sacerdotes como más directos colaboradores.

Éstas son las ideas básicas y sus propias palabras: «Venimos a una ciudad populosa, comercial, culta, donde se hace grata la vida al hombre (...) somos el responsable directo de sembrar las verdades que debéis creer (...) la fe que salva no está fuera de Iglesia Católica (...) pero necesitáis obras para que sea una fe viva (...) el que se desvía debe pararse a preguntar (...) el testimonio universal de enseñar y defender las mismas verdades es lo que hace más creíble a la Iglesia (...) el cristiano es el que piensa y vive como ciudadano del cielo (...) la ociosidad es cúmulo de males: hay que llenar con celo las actividades y obligaciones de la vida (...) El cabildo como más directo consejero debe profundizar en el estudio y la meditación para desempeñar su cargo. El clero debe defender los derechos de la Iglesia: amando la paz que divide a los cristianos, con un trabajo que llene por completo sus vidas y que su objeto y término sea la ciencia y la virtud; completándolo con una vida santa y perfecta» ${ }^{64}$.

\section{Cuestiones políticas con incidencia religiosa}

\section{La Gloriosa}

El 18 de septiembre de 1868 Cádiz afirmaba una vez más en el s. XIX español que era la abanderada del liberalismo. Andalucía occidental y Sevilla a la cabeza aceptan y difunden inmediatamente los ideales y consolidan social y geográficamente la «septembrina».

El Manifiesto de Cádiz - 19 de septiembre - traza las líneas básicas de los objetivos revolucionarios ${ }^{65}$. La Junta de Sevilla hace la concreción de las

64. Cf. B.E.O.M., 10-III-1869, 45-55.

65. «Queremos una legalidad común por todos creada, que tenga el respeto de todos; 
reivindicaciones que se propone sustentar y defender; es como el anteproyecto del edificio sociopolítico que se piensa construir ${ }^{66}$ y es revolucionario porque no se ha limitado a un mero cambio de orientación, personas, gobierno o régimen; se trata de cambiar los fundamentos del ser de España, implicando en ellos al pueblo como garantía y exigencia de que en ellos está la soberanía ${ }^{67}$.

\section{Sucesos en Málaga}

Málaga acepta la letra y el espíritu de los manifiestos de Cádiz y de Sevilla; su manifiesto será una mera copia del sevillano y se hace público el día 22. Inmediatamente después de su adhesión al movimiento revolucionario y como garantía de que dirigiendo al pueblo se puede ganar un poderoso aliado que decida el futuro hacia la consolidación de la revolución. La Junta Provisional malagueña pasa a dar unas medidas, que por ser populares, son bien acogidas por la mayoría ${ }^{68}$.

queremos que el encargo de observar y hacer observar la Constitución no sea un enemigo irreconciliable, queremos vivir la vida de honra y libertad, queremos que un gobierno provisional que represente todas las fuerzas vivas del país asegure el orden, en tanto que el sufragio universal echa los cimientos de nuestra regeneración social y política».

66. «1..$^{\circ}$ Sufragio universal y libre; $2 .^{\circ}$, Libertad absoluta de prensa; $3 .^{\circ}$, Consagración práctica de las demás libertades: enseñanza, cultos, tráfico, industria...; $4 .^{\circ}$ Abolición de la pena de muerte; $5 .^{\circ}$, Seguridad individual, inviolabilidad del domicilio y la correspondencia; $6 .^{\circ}$, Abolición de la Constitución bastarda que venía rigiendo y sustitución por la de 1856, sin el artículo concerniente a la religión del Estado, reglas de sucesión a la corona; $7 .^{\circ}$, Abolición de quintas, matrículas del mar y organización del ejército y la armada bajo el alistamiento voluntario; $8 .^{\circ}$, Igualdad en la participación de las cargas públicas; $9 .^{\circ}$, Desestanco de la sal y el tabaco y abolición de los derechos de puertos y consumos; $10 .^{\circ}$, Unidad de fueros y abolición de todos los especiales, incluso el eclesiástico, salvo los disciplinarios; $11 .^{\circ}$, Cortes constituyentes por sufragio universal directo...».

67. Cf. Cuenca Toribio, J.M., La Iglesia española ante la revolución liberal. Rialp.Madrid 1971, 200-201.

68. Se señala un haber diario de 10rs. a todos los individuos que se presenten armados con objeto de atender a la tranquilidad pública Arch. N.D. de E., leg. 303, 13.

-Para atender a las necesidades de las clases proletarias, se señalan $6 \mathrm{rs}$. diarios a todo el que se presente al trabajo de obras públicas a que se le destine. Ibid., 14.

- La Junta, en nombre del pueblo, decreta la disolución del ayuntamiento de la capital y pueblos de la provincia, los secretarios y jueces de 1 . $^{\mathrm{a}}$ instancia. Ibid., 25

- La Junta fija nuevos precios a los tabacos y sales; los descuentos oscilan entre $1 / 2$ y $1 / 3$. Ibid., 28.

- Se crean dos batallones francos - «la libertad» y «la patria»-y tendrán sus componentes 7 rs. diarios y ración de pan. Ibid., 30 .

-Estos batallones están compuestos por 6 compañias y 120 individuos. Son milicia popular porque esta Junta «reconoce que el pueblo armado es la más segura garantía para el sostenimiento de las libertades que nos hemos conquistado y que a todo trance es necesario asegurar». Cf. Boletín Oficial de la Provincia de Málaga, 8-X-1868, 2. En adelante citaremos B.O.P.M.

-Bando de la Junta para que en el término de 24 horas se presenten en la Aduana los agentes de la Seguridad pública, Municipales y Serenos a entregar las armas de fuego y blancas. Arch. N.D. de E., leg. 303,31 . 
Serrano y Prim desde la Rada se apresuran a infundir ánimos en el preciso momento en que es necesario ganarse afectivamente a un pueblo sensible para así asegurar efectivamente los pasos dados: «Malagueños: hemos conquistado la libertad; el pueblo de Torrijos ha respondido al pueblo de Riego. Viva la unión del pueblo y el ejército» ${ }^{69}$.

Más dueños de la situación porque la revolución sigue su camino, la Junta Revolucionaria de Málaga elabora una declaración de su pensamiento social y político, que es una explicitación más detallada del manifiesto ${ }^{70}$ y que pocos días después quedan incorporados muchos de sus puntos en la Declaración de Derechos que hace pública la Junta superior Revolucionaria en Madrid, el 8 de octubre.

En el campo religioso, las medidas adoptadas por las Juntas entran también en lo revolucionario, porque son una cadena de disposiciones restrictivas, anulaciones, prohibiciones y enajenaciones. Se respetan las personas, pero se ataca a las instituciones. No hay una orientación definida en la actuación religiosa de las Juntas; hasta que el Gobierno Provisional adopte medidas generales, y que son un compendio ecléctico de lo que han elaborado las Juntas provisionales provinciales, son éstas y no aquél las que tienen toda la iniciativa ${ }^{71}$.

También desde la prensa, los líderes demuestran su radicalismo y anticlericalismo ${ }^{72}$. Matiz agravante en el campo religioso es que el episcopado

-El ayuntamiento provisional decidió destituir de sus empleos a todo el personal (seoretaría, capellán, porteros, matadero, mercados, cementerios, guardas...). Archivo Municipal de Málaga, Actas Capitulares, 28-IX-1868. En adelante citaremos Arch. Mp. M., A.C.

- La Junta decreta un indulto a los presos por delitos leves. Arch. N.D. de E., leg. 303, 44.

69. Arch. N.D. de E., leg. 303, 34. Sin embargo ese mismo día, en el «Eco Revolucionario», se podía leer: "Algunos generales iniciadores del movimiento están entre nosotros. Malagueños hacedles oír a cada paso su palabra empeñada: realizar justicia; dejad las alabanzas para cuando hayan cumplido sus deberes. No os creáis una vez más en el caso de maldecir a quienes coronasteils» Ibid., 33.

70. B.O.P.M., 6-X-1868, 2.

71. El 12 de octubre la Junta revolucionaria suprime toda corporación, hermandad o sociedad con carácter religioso que no haya presentado ante esta Junta las listas de quiénes la componen, acompañándolas de los libros de actas y estatutos. Los que no cumplan estos requisitos están fuera de ley y serán entregados a los tribunales. Queda autorizado todo buen ciudadano para denunciar a los delincuentes de la infracción de este decreto. B.O. P.M., 14-X-1868, 2.

El 20 de octubre se acuerda la demolición de varios conventos y se convoca a aquellos ciudadanos que se crean con derecho a ellos para que se presenten con sus títulos de dominio. B.O,P.M., 23-X-1868, 2.

El 21 de octubre se acuerda la abolición y extinción de la sociedad religiosa de $\mathrm{S}$. Vicente de Paúl y otras de la misma índole, quedando prohibidos los hábitos respectivos. Arch. N.D. de E., leg. 303, 94.

El 19 de octubre se niegan la validez de los estudios del seminario conciliar a efectos civiles. B.O.P.M., 24-X-1868, 4.

72. Cf. el manifiesto de Félix Pyat, enviado desde Londres, 8-X-68, y publicado en el periódico liberal «La Iberia»: «De súbditos nos hemos convertido en ciudadanos... el emperador o rey mantendría soldados y curas, enemigos ambos del pueblo... creednos, la libertad no lleva uni- 
estaba conectado a la ideología del régimen recién caído y por lo tanto distaba mucho de comprender y aceptar - mucho menos encauzar- el hecho revolucionario ${ }^{73}$. Algunos obispos invidualmente o reunidos por archidiócesis hacen patente su protesta al Ministro de Gracia y Justicia o al Jefe del Gobierno Provisional por la legislación antirreligiosa que adopta a partir de los últimos días de octubre. Las "exposiciones» de los obispos se centran en reivindicar la unidad católica, enseñanza y protección de los seminarios, que se conserven las comunidades religiosas femeninas y el fuero eclesiástico ${ }^{74}$.

En Málaga la situación religiosa sufre más tensiones por encontrarse en esos días sin pastor. D. Esteban-José Pérez no tomará posesión hasta últimos de año. Estos meses transcurren con nerviosismo y sufriendo las consecuencias de toda interinidad. Falta la cabeza que imprima una postura oficial ante la cual el resto del clero sepa a quién recurrir y cómo actuar. En la capital y provincia, junto con algún otro caso en Cataluña, es donde algunos sacerdotes sufren ciertos atentados de diversa índole, hecho que aprovecha la revista sevillana «La Cruz» para que con cierto radicalismo ataque fuertemente al Gobierno que permite esas cosas ${ }^{75}$.

Durante noviembre empiezan a surgir movimientos de grupos y ciertas actuaciones incontroladas en hostilidad y franca rebeldía a la autoridad municipal y provincial ${ }^{76}$. Los numerosos grupos de «Voluntarios de la Libertad» habían sido el brazo armado de las Juntas Revolucionarias y su fuerza más persuasiva a la hora de consolidar el golpe de Cádiz; sin embargo, ahora se resistían sus componentes, que habían gustado el placer de la autoridad, a ser desarmados y volver a su anterior ocupación. Como un arma de doble filo, amenazaba con cortar a los que antes con ella habían cortado. El Gobierno es-

forme y la democracia no gasta sotana. La revolución no tiene frac ni hábito... quitad el sueldo al cura, licenciad los soldados..."

73. Cf. Cuencia Toribio, J.M., Iglesia..., o.c., 200-209. CÁrcel Orti, V., La Iglesia y revolución en España (1868-1874). Eunsa.- Pamplona 1979.- 682 págs.

74. Cf. CuEnCA Toribio, J.M., La Iglesia..., o.c., 197-246. Minucioso análisis de la presentación de la archidiócesis de Sevilla y las individuales de los obispos de Córdoba, Badajoz y Cádiz. Rodriguez DE CORO, F., El obispado de Vitoria durante el sexenio revolucionario. Caja Ahorros Municipal.- Vitoria 1976, 109-113, analiza la del obispo de Vitoria y en 118-121 la de los obispos de la archidiócesis de Burgos.

75. «Llamamos la atención a los señores ministros de la Gobernación y Gracia y Justicia sobre las precedentes líneas, y les rogamos que, por honra de España, por honra de la revolución misma, que al fin y al cabo por españoles ha sido hecha, repriman con mano fuerte atentados de esta clase... Es también digno de notarse que tanto en Málaga como en Antequera hayan sido sacerdotes las víctimas de estos inauditos atropellos; y que ni en uno ni en otro caso resulten motivos para la perpetración... no falta, por lo visto quien en vez de la pluma empuña el fusil o la pistola para hacer la guerra al catolicismo en la persona de sus ministros. Volvemos a decirlo: el decoro de España, el decoro del Gobierno, el decoro mismo de la revolución, exigen que estos escándalos no se repitan, porque en otro caso, será necesario emigrar a otro país, en donde se invoquen menos y se respeten más los derechos de los ciudadanos». 1868, II, 543-544. 
tá decidido: el orden público y la seguridad ciudadana no pueden, no deben depender de unos civiles provisional y urgentemente armados. El ejército resolverá la difícil tarea en aquellos lugares donde la resistencia o la negativa a obedecer hacen más problemática la misión.

El 30 de diciembre el alcalde se dirige a los malagueños anunciando que el general Caballero de Rodas viene a desarmar a la milicia popular y en su nombre viene primero el coronel Pavía anunciando que se deben depositar las armas en el local del Ayuntamiento ${ }^{77}$.

Los sucesos se precipitan y van tomando un carácter hosco que no presagian nada bueno. Al día siguiente a las alocuciones de los gobernadores civil y militar exhortando también a la entrega pacífica de las armas para reestructurar la milicia ciudadana, el presbítero, republicano y guerrillero - que de todo ello se jacta- Enrique Romero, pronuncia una alocución encendiendo los ánimos, ya de por sí calientes, de los milicianos ${ }^{78}$. Se declara el estado de sitio y se cede el mando a la autoridad militar ${ }^{79}$. Los milicianos responden ante la situación con barricadas. Los choques son violentos, la espiral de la violencia se desata en la ciudad. Son horas de horror y terror. El balance de las barricadas es el siguiente: 13 muertos y 32 heridos ${ }^{80}$, pero el número de inhumaciones nos da unas cifras bastante exactas de las víctimas habidas y las causas del fallecimiento. Durante los días 2 y 3 de enero de 1869, en el cementerio de S. Miguel reciben sepultura 107 cadáveres y 52 en el de S. Rafael ${ }^{81}$.

76. La Junta Revolucionaria, primero, y el Gobierno Civil, después, conscientes de que el ambiente en la capital y muchos pueblos de la provincia es preocupante, intentan dominar la situación por medio de comunicados, bandos y manifiestos:

- Prohíben circular impresos anónimos, allanamiento de moradas y que en círculos públicos se emitan ideas que perturben el orden. Arch. N.D. de E., leg. 303, 87.

-Que la revolución sigue obligando a satisfacer los atrasos contraídos con la Hacienda. Ibid., 89.

-Que aunque la Junta se disuelva es necesario prestar toda la cooperación al Gobernador Civil. Ibid., 96.

- Se denuncia a los que pretenden enemistar al pueblo con el ejército. Ibid., 123.

- Se difunde ampliamente el «Bando del Buen Gobierno» ante desmanes y desórdenes de todo tipo. Ibid., 125.

77. Arch. N.D. de E., leg. 303, 159. B.O.P.M., 31-XII-1868, suplemento.

78. "Vivir sin honra es la vida de la afrenta. Morir con gloria es la muerte de los héroes. Habemos puesto en armas a una ciudad que siempre ha sido la primera en el peligro de todas las libertades, para retirarnos en derrota sin demostrar por lo menos qué hay de valor en nuestros hechos. Milicianos: decidisteis ayer morir en vuestros puestos, primero que salir deshonrados. iA las armas! morir hoy es vivir como los mártires de Cádiz» Arch. N.D. de E., leg. 303,161.

79. B.O.P.M., 31-XII-1868, suplemento.

80. Cf. Porredon Ros, A., Reseña histórica de los acontecimientos de Málaga en los días 30 y 31 de diciembre de 1868 y 1 y 2 de enero de 1869.- Málaga 1869.- 56 págs. Arch. N.D. de E., leg. $303,162$.

81. Desglosando esas cifras, tenemos: -Cementerio de San Miguel: Heridos 
El 2 de enero el luto ha caído sobre Málaga y hay miedo de que el ejército pueda tomar represalias en los barrios que más dura fue la resistencia. Muy de mañana se hace público un bando del gobierno militar. D. Manuel Pavía Rodríguez ordena la entrega inmediata de las armas, salvo las que desde el principio estuvieron en manos de personas a las órdenes de la autoridad municipal. A los vecinos se les exigirá toda la responsabilidad en caso de encontrárseles algún efecto de guerra. El plazo terminaba ese mismo día a las tres de la tarde ${ }^{82}$.

La prensa recoge con dolor la crónica de los sucesos y hay como un acuerdo tácito de no ideologizar los pasados sucesos y únicamente informan de lo ocurrido ${ }^{83}$. El ayuntamiento en acto solidario de humanitarismo, acuerda pedir clemencia en favor de los presos de esos días ${ }^{84}$. El estado de sitio duró hasta el 12 de enero en que las barricadas habían casi desaparecido, el orden se había restablecido y la ciudad recobraba poco a poco su ritmo normal ${ }^{85}$.

El 13 de enero la Iglesia quiere clarificar posturas y decir una palabra que alumbre un poco la oscuridad, sin entrar a juzgar las motivaciones políticas que han motivado los sucesos. «Tristes acontecimientos los ocurridos el día 31 de diciembre y el 1 de enero que han dejado sangrientas huellas... para nosotros no existen vencidos o vencedores, todos tienen igual derecho a nuestra solicitud, todos son nuestros hermanos y en ellos sólo consideramos una cosa: que sufren y por lo tanto que nos necesitan... promovemos una suscripción voluntaria con qué socorrer tantas necesidades»" ${ }^{86}$.

La catedral fue invadida durante tres días por tropas de la milicia popular leales al Gobierno. No ocurrió ningụn desmán notable, pero según las rúbricas de la Iglesia Romana había que practicar la «réconciliación». El cabildo decide celebrar honras fúnebres por las víctimas el día 21 y el día 25 pide el Ayuntamiento que se celebren también bajo su patrocinio ${ }^{87}$.

$\begin{array}{llc} & & \\ & \text { Enfermos comunes } & 20 \\ & \text { Causas ignoradas } & 8 \\ & \text { TOTAL } & 107 \\ \text {-Cementerio de San Rafael: } & \text { Soldados } & 15 \\ & \text { Civiles } & 36 \\ & \text { Mujeres } & 1 \\ & \text { TOTAL } & 52\end{array}$

Arch. N.D. de E., leg. 302, carp. 6,3. Según la lista impresa con los nombres de las víctimas, tendríamos:

-Muertos: 99: 94 varones y 5 hembras.

-Heridos: 109: 92 varones y 17 hembras. Ibid., 4.

82. Arch. N.D. de E., leg. 302, carp. 6,8.

83. «Diario Mercantil», 3-I-1869 y 5-I-1869. «El Avisador Malagueño», 9-I-1869.

84. Arch. Mp. M., A.C., 3-I-1869, 2.

85. B.O.P.M., 12-I-1869,1.

86. B.O.P.M., 15-I-1869, 2.

87. Arch. C.M., A.C., t. 70, 12-I-1869. 24-I-1869. Arch. Mp. M., A.C., 21-I-1869, 27. 


\section{Unidad religiosa}

El tema de la libertad de cultos había sido un banderín de enganche para conseguir que algunos remisos se adhiriesen al carro de la «septembrina». Todos los manifiestos de las Juntas Revolucionarias lo incluyen entre sus reivindicacionés ${ }^{88}$, como signo de ataque inequívoco a la Iglesia Católica por sus connivencias ideológicas con el régimen isabelino y por su espíritu netamente clasista, anclado aún en el recuerdo no demasiado lejano de cuando la Iglesia tenía poder político y económico.

Una vez abierto el periodo constituyente donde se planeaba el desenganche oficial que pretendía conseguir el Estado respecto a la Iglesia, era lógico esperar una lluvia de lamentos por aquellas fuerzas oficiales del catolicismo que aún seguían uniendo indisolublemente catolicismo con Estado español y, por lo tanto, no imaginaban la posibilidad de que llegase una separación respetuosa, y de que la Iglesia Católica - aunque fuera la mayoritaria- se pusiese en el mismo peldaño que cualquier otra confesión religiosa, siendo el número de fieles y su vivencia a nivel de concienca colectiva y personal, lo que debía haber importado, y no poner todo su empeño en reclamar la permanencia de unós privilegios que desde luego a la Iglesia no beneficiaban y sí la predisponían para que en el futuro pudiese emprender un diálogo con los demás hombres e Iglesias. Responsable de su misión presente, no cimentada en principios objetivos y sin otear al horizonte donde Dios también suele hablar, puso su esfuerzo en quedar anclada en el pasado, por la inercia de que había vivido bien y se negó a jugar la baza de la esperanza, que también es una virtud teologal, aunque le hubiese costado el sacrificio de trabajar y rezar mirando a Dios ${ }^{89}$.

El obispo de Málaga aún no ha tomado posesión en esas fechas, pero el período constituyente de los primeros meses del 69 le van a dar sobrada oportunidad para dirigir su exposición a las altas instancias del poder Legislativo; cuenta con la ventaja de manejar los textos de los obispos que ya lo han hecho y centra su escrito en el tema de la unidad religiosa. No quiere meterse en política, pero como obispo católico y ciudadano español también habla en nombre del pueblo al que pastorea. Cree que la cuestión se debe centrar en si es conveniente para España que deje de ser católica, piensa lo desastroso que sería una guerra de religión y que los derechos de libertad religiosa están en la verdadera religión. Sigue influyendo en su pensamiento la ley del número, los

88. Véase el de Sevilla como uno de loś pioneros y que va a servir a muchas Juntas. Más tardío el de Madrid -25-X-1868 - afirma que de todas las libertades, la más importante, por la alteración que introducía en la organización secular de España, era la relativa al planteamiento de la libertad religiosa. BOZAL, J., Juntas revolucionarias. Manifiestos y proclamas de 1868. Edicusa.- Madrid 1968, 111.

89. Cuenca Toribio, J.M., La Iglesia... o.c., 227. 
compromisos concordatarios y el presentimiento de que la falta de unidad religiosa traería irremisiblemente la ruptura de la unidad política ${ }^{90}$.

En una palabra, el duelo entre jerarquía y defensores del libre culto se reducía - como observa Cuenca Toribio- a que la Jerarquía rechazó siempre hasta el simple hecho de considerar la libertad religiosa como un derecho inherente de la persona humana. La Iglesia española mantuvo en todo momento una clara postura discriminatoria y privilegiada de la libertad de creencias sin verla como un derecho divino-natural ${ }^{91}$. La postura radical del episcopado alcanzó hasta la teoría del «mal menor», cerrando toda posible vía intermedia de solución. Ante esto sólo quedaba el camino de la declaración de libertad religiosa, que posiblemente, con habilidad y sin arrogancia de privilegios, en la mesa de las negociaciones, jerarquía y fieles hubiesen podido conseguir en el terreno de las cosas concretas, establecer un estatuto jurídico de tolerancia religiosa ${ }^{92}$.

\section{Incautación de documentos eclesiásticos}

El Gobierno Provisional sigue dando medidas que lesionan lo eclesial. A primeros de enero del 69 se incautan todos los documentos eclesiásticos. El lunes día 25 por la mañana se presentó la autoridad gubernativa en la sala Capitular de la catedral con este cometido y trasladó todos los documentos al cuarto de «desayunos» cerrándolo y sellándolo ${ }^{93}$. Dada la humedad de la sala designada para almacenar los documentos, el cabildo propone a la autoridad civil de la provincia que se abra el local ${ }^{94} \mathrm{y}$ esa misma.petición se hace al Ministro de Fomento ${ }^{95}$. El gobernador civil recibe comunicación del ministerio de fomento de que se accede a lo solicitado por el cabildo ${ }^{96}$.

90. Cf. B.O.P.M., 31-III-1869, 69-73.

91. En la más absoluta cerrazón o ceguera ante la realidad, se niega el derecho y la posibilidad de que los españoles pudieran tener algún otro tipo de creencias, fuera de la ortodoxa. También los obispos de la andalucía occidental tropezaron en la misma piedra. CUENCA TORIBIO, J.M., La Iglesia..., o.c., 229.

92. Cuenca Toribio, J.M., El pontificado pamplonés de D. Pedro Cirilo y Labayru (18621870). «Hispania Sacra» (Madrid-Barcelona), 43-44 (1969), 129-157. La recién fundada Asociación de Católicos había organizado una campaña nacional de recogida de firmas en favor de la unidad católica. Los párrocos fueron el apoyo indispensable, porque ellos lo deberían mover en cada una de sus Iglesias. Las normas concretas de presentarlas pueden verse en la revista «La Cruz», 1869, I, 88-90. Se recogieron casi 3 millones de firmas cuyos pliegos en cinco coches de gala entregó oficialmente en las Cortes el obispo A. Monescillo y Viso, que era diputado, el 6-III1869. También fue «La Cruz» la que recogió con todo lujo de detalles esta ceremonia. Cf. 1869, I, 491-492. En la diócesis de Málaga éstos fueron los resultados: se respondió en 12 pueblos y se recogieron 12.197 firmas. CÁRCEL ORTI, V., La Iglesia... o.c., 549.

93. Arch. C.M., A.C., t. 70, 26-I-1869.

94. Ibid., 27-III-1869.

95. Ibid. leg. 705 , sin numerar.

96. Ibid., A.C., T. 70, 15-VII-1869. 
Pasan los meses y con ellos el cálido fervor que sə propuso el gobierno de destinar los documentos incautados a unos centros especiales para su estudio y aprovechamiento del pueblo, estudiantes o curiosos. Los documentos seguían en la habitación húmeda, hacinados ya dos años y medio, con manifiesto deterioro y amenaza de perderse. El cabildo se dirige una vez más al gobierno ${ }^{97}$ y el silencio sigue siendo la respuesta, cayendo en la contradicción práctica de dejar estropear lo que había incautado para conservarlo mejor. Hasta marzo de 1872 el gobernador civil no recibe una R.O., en contestación a la angustiosa solicitud del cabildo, por la que se determina autorizar la apertura del aposento donde están despositados los documentos incautados ${ }^{98}$.

\section{Primera expropiación de conventos}

Una de las primeras medidas de la Junta Revolucionaria de Málaga -20$\mathrm{X}-1868$ - había sido la demolición de varios conventos de monjas ${ }^{99}$. El ayuntamiento pasó a solicitar del ministerio de Hacienda la propiedad de los conventos expropiados ${ }^{100}$. Las razones aducidas, fueron: $1 .^{a}$ ) utilidad y orden público, $2 .^{a}$ ) proporcionaría trabajo a gran número de jornaleros sin ocupación, $3 .^{a}$ ) por la cesión de la propiedad y venta de los solares se podría traer pronto las aguas de Torremolinos a la capital ${ }^{101}$.

Se despliega una actividad inusitada en torno a este asunto. Se ordena al arquitecto municipal que forme planos de los solares de los conventos en derribo y divida sus áreas en solares adecuados a la enajenación ${ }^{102}$. Pocos días después un nuevo proyecto sobre la distribución de los terrenos se presenta al pleno de la Corporación ${ }^{103}$. Como dato curioso y contradictorio, el Ayunta-

97. Ibid., t. 71, 7-VII-1871, 12v.-13v.

98. El canónigo Francisco Núñez Gallo, como miembro del cabildo, estuvo presente en la apertura del aposento y recibió la entrega del archivo incautado de manos del Jefe provincial de Fomento. Arch. C.M., A.C., t. 71, 13-11I-1872, 7v-8v.

99. B.O.P.M., 23-X-1868, 2. Se trataba de los conventos de S. Bernardo, sito en la calle Granada y cuya fundación databa de 1543 y el de Sta. Clara, sito también en la misma calle y cuya fundación databa de 1495, habiéndose agregado a él las monjas del convento de La Paz cuando ese edificio pasó a ser cuartel. Cf. Mazo, I., Historia de Málaga, t. II, 36ss. Guillén Robles, F., Historia de Málaga y su provincia.- Rubio y Cano.- Málaga 1874.- 516 y 522.

100. Arch. Mp. M., A.C., 8-I-1869, 13.

101. Claras razones revolucionarias, apoyadas en la política de hechos consumados. La concesión y fines que hace la Dirección General de Propiedades queda clara cuando insiste en «que se vigile que el producto de la venta se dedica a ese fin para el que se ceden aquellos conventos» Ibid., 8-I-1869, 14.

102. El anteproyecto del arquitecto municipal arroja estas cifras:

-Convento de S. Bernardo: 2.971 metros cuadrados, que a razón de 50 escudos por $\mathrm{m}$. dan el total de $1.485 .500 \mathrm{rs}$.

-Convento de Sta. Clara: 4.374 metros cuadrados, que a razón de 34 escudos por $\mathrm{m}$. dan un total de 1.487 .160 rs.

Arch. Mp. M., A.C., 1-III-1869, 73v.-74.

103. Del convento de S. Bernardo: 2 manzanas con 9 lotes (6 manzanas la mayor y 3 la me- 
miento gasta en esos mismos días 1.100 reales por colocar el Tabernáculo de mármol, procedente del derribado convento de Sta. Clara, en la Iglesia de la Victoria a la que lo destinan, ya que sus legítimos propietarios lo habían cedido al Ayuntamiento ${ }^{104}$.

El derribo de los conventos se aprovecha también para dar mayor amplitud a las calles correspondientes, para abrir otras nuevas y para igualar las alineaciones de las futuras construcciones a las zonas de población contiguas a aquellas ${ }^{105}$. Sin embargo, como en tantas otras cosas, el Ayuntamiento perdió interés, el tiempo pasaba y los conventos no acababan de llegar al suelo; las actas del cabildo municipal dejan buena constancia de que el tema se trataba una y otra vez, pero no pasaba del muro del salón de sesiones a la realización práctica. El atasco parece ser que estaba en no tener claras las condiciones en el contrato de derribos. La Administración Económica de la provincia urge al Ayuntamiento a que entregue los solares y decide que el próximo día 30 de octubre se entregarán ${ }^{106}$; también se urge a la comisión encargada que fijen definitivamente las calles y alineaciones de los solares para proceder a la subasta pública ${ }^{107}$. Las condiciones del contrato de derribo siguen sin clarificar en diciembre ${ }^{108}$.

El alcalde urge a los arquitectos municipal y provincial para que tasen los solares que van a salir a venta pública, ya que los últimos trámites de demarcación de calles y alineaciones está resuelto ${ }^{109}$. Por fin en el mes de marzo salen a subasta los solares de los ex-conventos. El resultado es el siguiente:

-Convento de San Bernardo:

- Lotes vendidos: 6.

- Total de metros cuadrados: 2.626 .

nor). Del convento de Sta. Clara: 3 porciones con 13 lotes. Arch. Mp. M., A.C., 15-111-1869, 92v.93.

104. Ibid., 18-III-1869, 96v.

105. Ibid., 12-VII-1869, $285 \mathrm{v}$.

106.' Ibid., 30-VIII-1869, 352v.-359 y 27-IX-1869, 401-407. El contratista D. Álvaro Gámez pide demórar la entrega de los solares hasta que desaloje los materiales que allí tiene. Ibid., 18-IX$1869,378 \mathrm{v}$.

107. Arch. Mp. M., A.C., 30-IX-1868, 407v.-410. Lo normal es que el ayuntamiento para solucionar un problema ocasione otro. A la hora de fijar la alineación de la calle, y como el obstáculo era también de índole religiosa - convento de Capuchinas-, aprovecha para una remodelación, ordenando la demolición de la fachada del convento que da a la calle de S. Agustín y tomando $4 \mathrm{~m}$. Así ahora la calle —no toda - tendrá $8 \mathrm{~m}$. de ancho. Ibid., 27-I-1870, 36. La subasta de la obra salió en 4.000 escudos y fue adjudicada en 2.500 al contratista D. Gabriel García. Ibid., 3-II-1870, 38v.

108. Ibid., 5-X11-1869, 439.

109. Las calles nuevas y los nombres que se les ponen son:-Duque de la Victoria: de Granada a S. Agustín. - Méndez Núñez: de Granada a Cañuelo. -Molina Lario: De Duque de la Victoria a Sta. María. Ibid., 10-I-1870, 7. 
- Resto de metros cuadrados: 345 .

- Total obtenido: 76.832 escudos.

-Convento de Santa Clara:

- Lotes vendidos: 14.

- Total de metros cuadrados: 3.434 .

- Resto de metros cuadrados: 940.

- Total obtenido: 119.251 escudos ${ }^{110}$.

Como no podían terminar aquí los problemas, se descubrió por uno de los compradores - y elevó su correspondiente protesta- que las medidas oficiales subastadas no correspondían a la realidad. Rápidamente se verificó una nueva medición, culpando del posible error a la «falta de destreza del anciano señor arquitecto municipal». Como también estaba en juego el prestifio de la Administración Económica de la provincia, nombró un perito que rectificase las medidas ${ }^{111}$.

A la hora de firmar las escrituras del legítimo dominio, previa cesión de la Hacienda al Ayuntamiento para que éste las otorgue a los compradores, la Corporación llega al acuerdo de reintegrar a la Hacienda el precio de los solares ahora vendidos con el primer fruto de las aguas traídas de Torremolinos ${ }^{112}$. Los señores C.M. Heredia e hijos y Larios e hijos, otorgan una escritura para responder al Ayuntamiento de los valores que éste deposite en el banco por los productos de los solares vendidos con destino a las obras de traídas de aguas de Torremolinos a la ciudad ${ }^{113}$.

Otra prolongada polémica se cierne sobre el ex-convento de S. Agustín. El Ayuntamiento se dirige al Gobierno Provisional - a través del Gobernador Civil- solicitando confirmase la cesión del edificio hecha a la Corporación por la Junta Revolucionaria. No se tenía en cuenta -o no quería tenerseque el 28-V-63 se había hecho escritura de cesión del edificio al Seminario y por R.O. del Ministerio de Gracia y Justicia de 7-VIII-63, S.M. se sirvió «prestar su soberana aprobación a la referida escritura de traslación perpetua del pleno dominio del edificio, que fue convento de S. Agustín» (véase nota 16). Sin esperar confirmación de la solicitud dirigida al G. Provisional, el Ayuntamiento traslada sus dependencias desde sus Casas Consistoriales, sitas en la plaza de la Constitución al ex-convento de S. Agustín y el día 22-II-1869 celebra allí sesión por primera vez ${ }^{114}$.

En la primavera de ese año, el gobierno civil trasmite al ayuntamiento una resolución de la Dirección General de Propiedades y Derechos del Estado',

110. Ibid., 1-III-1870, 61-65. 71. 7-III-1870, 68-70.

111. Ibid., 21-III-1870, 88v.-89. 24-III-1870, 89v.-90.

112. Ibid., 6-VI-1870, 147-150.

113. Ibid., 27-X-1870, 268.

114. Ibid., 22-II-1869, 67. 
contestando negativamente a la solicitud formulada meses antes por la corporación malagueña ${ }^{115}$. Oficialmente el ayuntamiento no acepta esta resolución y se urge a los abogados municipales que elaboren un informe legal sobre si el ayuntamiento tiene derechos de propiedad sobre el edificio. Meses después se propone conocer el cabildo municipal el resultado de las consultas hechas a los abogados, sin obtener una respuesta ${ }^{116}$.

Después de un silencio de casi dos años, en los cuales el ayuntamiento ha seguido ocupando el edificio como suyo, vuelve a resucitar el tema de la propiedad. Se recibe un oficio del Administrador Económico con fecha 18-IV1871, en el que se hace relación al decreto de 21-III-1869, según el cual el ayuntamiento se creía con derecho a la propiead del edificio y así lo pedía al Gobierno. Se vuelve a insistir en la resolución de la Dirección General de Propiedades de 21-IV-1869, en la que se negaba al ayuntamiento el derecho de propiedad. Nuevamente la Corporación acuerda reclamar al Gobierno, ya que estuvieron en posesión más de diecinueve años seguidos antes de su cesión al obispado el año $1861{ }^{117}$.

Los primeros días de la restauración traen a primer plano nuevamente el problema. El decreto de 9-I-1875 pretendía reparar los abusos cometidos por disposiciones posteriores a las celebradas con la Santa Sede en 1860 y que pretendieron solucionar el problema de la permuta de los bienes del clero ${ }^{118}$. El artículo $1 .^{\circ}$ de la citada Ley dejaba un pequeño resquicio - «que no se hallasen aplicados a servicios públicos»- pero el espíritu de la ley y la intencionalidad estaban suficientemente explícitos. El ayuntamiento reconoció como propietarios del ex-convento de S. Agustín al obispado y celebró, con garantías jurídicas, contrato de arriendo, consecuencia del cual es una deuda reconocida por la corporación, pero no pagada ${ }^{119}$.

\section{Guerra Carlista y juramento de la Constitución}

El ministro Ruiz Zorrilla prepara una exposición en la que explica motivos y causas que le mueven, de acuerdo con el Consejo de ministros, al some-

115. «...resultando de los dichos documentos que enviaron y de los que obran en este centro, por R.O. de 17-VII-1861 fue exceptuado de la permutación el expresado edificio conforme a lo establecido en el art. $6 .^{\circ}$ del convenio celebrado con la Sta. Sede y entregado al arzobispo (sic) de esa diócesis para los usos de su instituto y siendo hoy propiedad de la Iglesia mediante el citado convenio, no residen facultades en el Estado para disponer del mismo» Ibid., 6-IV-1869. $159 \mathrm{v} .-160$.

116. Ibid., 1-V-1869, 165v. 7-VII-1869, 200-201v.

117. Ibid., 29-V-1871, 119-119v.

118. El art. $1 .^{\circ}$ zanjaba definitivamente el largo proceso que nos ocupa. «Los Jefes económicos de acuerdo con los obispos pondrán a disposición de los mismos aquellas propiedades d clero que exceptuadas de la permutación concordada con la Sta. Sede en 1860 existan hoy en ro der del Estado y no se hallen aplicadas a servicios públicos».

119. Valle Zamudio, M., Apuntes... o.c., 140. 
ter el decreto a aprobación del Regente. He aquí los nuevos sambenitos colgados en las ya poco libres espaldas del clero: «parte del clero enciende con ardor inusitado y criminal empeño la tea de la discordia... en favor de los enemigos de nuestras libertades... trocando la figura del sacerdote católico en paladín de mundanos intereses (...) No deben ser tantas las escaseces económicas del clero, cuando con recursos propios realizan empréstitos para allegar medios y facilitar el triunfo de la causa carlista (...) El gobierno manifiesta la firme energía con que está dispuesto a reprimir toda tentativa de retroceso en la marcha política inaugurada por la revolución de septiembre (...) Gran número de sacerdotes han declarado la guerra desde el púlpito y en todas partes (...) Este decreto servirá para mantener el lustre del clero y para velar por la seguridad del Estado y castigar a los eclesiásticos que abusan de su ministerio»" ${ }^{120}$.

Con tal preámbulo la ley no podía quedar atrás: los obispos debían dar cuenta inmediata de los clérigos que abandonasen las Iglesias y combatiesen la presente situación política; también deberían informar de las medidas canónicas aplicadas para corrección o castigo. Además, les retirarán las licencias -a los sacerdotes - de confesar y predicar. Y para obligar a los obispos indecisos a tomar el decreto en consideración, en el plazo de ocho días, deberían hacer público en el territorio de su diócesis, un edicto pastoral exhortando a obedecer a las autoridades constituidas y remitir copia a la secretaría del ministerio de Gracia y Justicia ${ }^{121}$.

El obispo de Málaga se siente ajeno al problema planteado, por sí y por su clero, pero da cumplimiento a lo mandado en el decreto y publica una circular dirigida al clero. Quiere dejar bien claro la doctrina y su situación en Málaga: «Los clérigos que se consagran exclusivamente a los negocios seculares son apóstatas; los que intervienen y contribuyen a la lucha política son desertores; los que predican subversión al orden religioso, moral y social y se lanzan a la rebelión y combate, vengan de donde vengan y sea cual sea su bandera, son falsos apóstoles; los que seducen al pueblo, lo conducen a la lucha o toman parte en ella, están fuera del verdadero sacerdocio (...) aunque no lo necesiten, debemos recomendaros el exacto cumplimiento de vuestros deberes») ${ }^{122}$.

El 17-III-1870 se hace público un decreto por el que se exige a todo el clero de la nación que por su oficio eclesiástico percibiese haber del presupuesto del Estado, preste juramento a la Constitución. En la diócesis malagueña se presenta el problema - como en otras - de que su pastor estaba en Roma en las sesiones del Concilio Vaticano I. El deán comunica al cabildo que había

120. Cf. B.O.P.M., 16-VIII-1869, 211-213.

121. Palacio de la Granja de San Ildefonso, 5-VIII-1869, 213-214.

122. Circular 79, B.O.O.M., 15-VIII-1869, 207-211. 
consultado con Roma y esperaba contestación. El canónigo doctoral y secretario de cámara leyó una carta personal y confidencial que había recibido el día anterior del prelado, en la que le anuncia que aguarda al resto de los obispos españoles para dar una respuesta cuando estén de acuerdo y tengan el visto bueno del papa ${ }^{123}$. El decreto sólo concedía el plazo de un mes para efectuar el juramento; la respuesta de Roma tardaba. Había que ganar tiempo y el gobernador eclesiástico decide enviar una exposición al Sr. Regente pidiéndole amplíe el plazo hasta haber evacuado consultas con el obispo, que como sabe, está en Roma ${ }^{124}$. D. Antonio de Vargas tranquiliza también al clero malagueño que con cierto temor se dirige a él en busca de soiuciones prácticas ${ }^{125}$.

El 1-V-70 se recibe un comunicado de la Nunciatura: «Acaba de recibirse el siguiente telegrama: en consecuencia de la nueva declaración dirigida a la $\mathrm{S}$. Sede por ese Gobierno con fecha 11-IV, habiendo cesado las dudas ocurridas por algunas frases contenidas en el preámbulo del decreto de 17-III, la S. Sede confirma las instrucciones comunicadas en septiembre del pasado año, a saber: que nada obsta para que los obispos y el clero presten juramento a la Constitución de 1869. El Cardenal Antonelli, Secretario de Estado. Roma, 26IV-1870» ${ }^{126}$.

No puede por menos de sorprendernos que desde septiembre ya se hubiera tomado una postura oficial por parte de la S. Sede y en estos momentos no cuente para nada la opinión de los 38 obispos que en esos momentos están en Roma y con los que no se evacuan consultas a nivel oficial y colectivo. Además, el telegrama de la Secretaría de Estado lleva la misma fecha que la exposición colectiva al Regente que los obispos envían desde Roma, siendo el contenido sustancialmente diverso al del telegrama recibido en la Nunciatura de Madrid. ¿Conocía el Gobierno oficiosamente la existencia del comunicado de septiembre del 69 y quería un reconocimiento formal ante el que los obispos tendrían que bajar la cabeza? ¿Prentendía desautorizar el Vaticano a los obispos para manifestar una vez más que el interlocutor válido con el Estado español en asuntos religiosos era sólo la Sede Apostólica? Sin embargo, las razones que dan los obispos en la carta colectiva son bastante consecuentes con los momentos que vive España ${ }^{127}$.

No hay que olvidar que el tema del juramento de la Constitución venía arrastrando una fuerte polémica en las altas esferas políticas del Gobierno español y no pocas tensiones con la S. Sede. Había empezado con el nuncio Franchi y el ministro Lorenzana y Romero Ortiz; después de un cambio de

123. Arch. C.M., A.C., t. 70, 2-V-1870.

124. Ibid., leg. 706, sin numerar.

125. Circular 102. B.E.O.M., 6-IV-1870, 370-371.

126. Arch. C.M., A.C. t. 70, 2-V-1870, 375-378.

127. Cf. B.E.O.M., 14-V-1870, 375-378. 
Gobierno sigue el problema con Silvela y Martín de Herrera y aún habrá de llegar otro nuevo inquilino a la cartera de Gracia y Justicia, Ruiz de Zorrilla y después otro, Montero Ríos, junto con un nuevo nuncio, Bianchi, para poner fin a un encontrado asunto que había sido politizado y sacado de sus coordenadas más que tratado aceptado objetivamente.

\section{Dotación de culto y clero}

Ya hemos visto que para el ejercicio económico 1867-68 se había rebajado a la dotación un $5 \%$. El año 1869 trae novedades en los presupuestos eclesiásticos. De la compleja «orden de rebaja» — no se satisfará la dotación de mitras y dignidades vacantes, se anula cualquier tipo de aumento, se rebaja al mínimo la asignación de culto, gastos de administración y visita, se suprime la dotación de seminarios conciliares, y bibliotecas y la de junta de reparación de templos, etc., el cabildo de la catedral de Málaga tiene una cosa clara: a partir del 1-VII su dotación para culto y clero queda reducida a 70.000 reales, aproximadamente un tercio de lo que antes recibía; ese descuento o reducción de $1 / 3$ es la que pretende aplicar a todos los gastes de culto y personal ${ }^{128}$. La reducción era demasiado drástica como para no sentirse. Próxima ya la Semana Santa y habiéndose agravado la situación desde julio del pasado año, el cabildo decide dirigirse al Regente pidiendo ayuda. Conocedores de que las cosas de palacio van despacio, en el mismo número del boletín donde se publica la exposición que ha dirigido el cabildo, se inserta una nota indicando que en la catedral se admiten donativos para el culto y los ministros. Una semana después, en la misma publicación, se dan las gracias porque el pueblo malagueño ha demostrado bien a las claras que es católico. Se han recogido 12.015 reales y 291,5 libras de cera ${ }^{129}$.

En vista de la buena acogida que ha tenido la petición del cabildo al pueblo malagueño y de que el Gobierno no contesta a la petición de auxilio, se decide seguir recibiendo donativos durante los días de la Semana Santa ${ }^{130}$. En las actas capitulares empiezan a menudear por estas fechas las peticiones de «socorro» de salmistas, ministros, organistas o seises «para su necesario sustento». De momento no se ve salida a la situación económica, que en alguno de los casos empieza a ser angustiosa. El cabildo decide enviar una circular a los fieles solicitando una limosna voluntaria y fija mientras dure esta situación y así lo hace saber a clero y fieles a través del boletín eclesiástico, al tiempo que recomienda al clero parroquial de la diócesis que también lo hagan ${ }^{131}$.

128. Arch. C.M., A.C., t. 70, 24-VII-1869.

129. Circular 105. B.E.O.M., 14-V-1870, 379-380. También se había pensado poco antes hacer una petición a las familias principales de la ciudad, pero no se llevó a cabo por no parecer oportuna. Arch. C.M., A.C., t. 70, 15-III-70.

130. Ibid., 7-IV-1870. La recaudación total de esos días ascendió a 11.385 rs. y 280 libras de cera. Ibid., 2-V-1870.

131. Ibid., leg. 733, sin numerar. C. B.E.O.M., 10-VI-1870, 387-391. 
El primer mes se recogen 6.940 reales de 358 donantes ${ }^{132}$. También se pide permiso que del dinero existente de expolios y vacantes se pueda tomar algo para la fábrica de la catedral. El Regente permite tomar la mitad y la cifra asciende a 16.208 reales y 4 maravedíes ${ }^{133}$. El turno de lamentaciones pasa ahora por los beneficiados que argumentan al obispo que por su obligación coral no pueden buscar misas y cualquier ministerio en otras Iglesias ${ }^{134}$. El obispo intenta paliar y escribir personalmente al Regente, aunque sin prometer ningún éxito ${ }^{135}$.

El 16-I-1871 se intenta poner solución en parte al grave problema de la dotación con un decreto que tiene como base aprovechar el ingreso de la Bula de la Cruzada ${ }^{136}$. Así lo comunica el obispo: se satisfarán los atrasos hasta la fecha del juramento de la Constitución en billetes del tesoro ${ }^{137}$. El cabildo publica una circular a los fieles agradeciendo la respuesta que han dado a la suscripción voluntaria ${ }^{138}$. De esta forma el problema sólo se había solucionado en parte, porque el decreto del 16-I satisfacía únicamente lo relacionado con el culto; quedaba todavía el aspecto personal del clero, que desde abril del 70 habían sido privados de sus dotaciones. El Gobierno ante la también penosa situación de la Hacienda, decide recortar sensiblemente los presupuestos, limitándose a lo estrictamente esencial. Así hay que entender la exposición que hace el ministro Montero Ríos al Rey Amadeo I, para que pase a decreto ${ }^{139}$. La nueva situación trae una reducción en las dotaciones de un $30 \%$ a partir de octubre. El cabildo estúdia el problema y decide que de los fondos de li-

132. Arch. C.M., leg. 706, sin numerar.

133. Ibid., leg. 246, 85 .

134. «De seguir así tendremos que buscar algo para subsistir, en la ciudad o fuera de ella». Málaga, 18-VII-1870. Ibid.

135. Prueba de que la situación es mala para todos los estamentos del clero y oficiales de la catedral es que en el mes de agosto se han adelantado en concepto de «socorro» 1.201 reales, a los siguientes señores: canónigo penitenciario, pertiguero, caniculario, 2 celadores, 4 salmistas, 3 ministros de coro, 1 organista, 1 alcaide de coro, 4 acólitos, 5 seises, 2 peones y 1 campanero. Arch. C.M., A.C., t. 70, 25-VIII-1870. Leg. 706, sin numerar.

136. El ministro de Gracia y Justicia explicaba en el preámbulo, las fuentes de financiación: «El producto de las limosnas de la Bula de la Cruzada ingresa o debe ingresar íntegramente en el Tesoro y forma parte del presupuesto General del Estado para destinarse con preferencia a las atenciones del culto... La situación aflictiva de la Hacienda ha impedido ahora y en épocas anteriores que este producto se haya dedicado al objeto para el que debe estar exclusivamente destinado... El actual Gobierno cree conveniente que el producto de la Cruzada, sin dejar de computarse como parte del presupuesto eclesiástico, se aplique directamente por los administradores diocesanos al culto y a ese fin somete el presente decreto de acuerdo con el ministro de Hacienda y conforme a lo acordado con la Sta. Sede Madrid. 14-I-1871». Cf. B.E.O.M., 18-II-1871, 495-496.

137. Arch. C.M., A.C., t. 71, 22-IV-1871, 8v.

138. Ibid., leg. 706, sin numerar. De acuerdo con el obispo, desde el mes de junio debe cesar la cuestación voluntaria que desde julio del pasado año se venía realizando entre los fieles. Ibid., t. 71, 7-VI-1871, 10v.

139. El decreto sería firmado pocos días después en Barcelona. Cf. B.E.O.M., 5-X-1871, 608-609. 
mosnas se completará lo que falte para que todos los dependientes de la catedral que cobraban su sueldo de la dotación, sigan haciéndolo hasta el mes de diciembre, pero con el aviso de que en enero se aplicará dicha reducción ${ }^{140}$. En vista de que el Gobierno no contesta a la exposición enviada hacía diez meses, el cabildo decide que se persone en Madrid el Arcediano, con todas las facultades necesarias, para intentar solucionar el problema. Habían transcurrido veintitrés meses cuando el Gobierno da luz verde y determina abonar los atrasos ${ }^{141}$.

El otoño traería nuevas novedades sobre este tema, cuando el 21-IX se hace público el proyecto de ley que presenta al congreso el titular de Gracia y Justicia sobre «el arreglo del clero»; se trataba de pasar la obligación de abonar la dotación a las respectivas provincias y municipios. D. Esteban-José Pérez se dirige nuevamente, amparado en el artículo 17 de la Constitución, a las Cơrtes: «El referido proyecto rompe hasta la última página que quedaba del Concordato de 1851 ... porque el origen de las dotaciones por parte del Estado es la obligación que tiene de indemnizar para que nunca se le llama con el nombre que da el derecho a quien se apropia de lo ajeno contra la voluntad de su dueño (...) Es injusto también con relación al Municipio y a la Provincia. Y no se puede hacer la transferencia de obligaciones sin que se altere el art. 21 de la Constitución en la que se dice que 'la nación se obliga a mantener el culto y los ministros de la religión católica' (...) es injusto también con relación al clero, porque le limita el derecho de adquirir y poseer que por otro lado le garantiza el art. 13 de la Constitución (...) Pero sobre todo pone en abierta oposición al clero con el Municipio y Provincia, porque estas entidades, especialmente desde 1869 con toda su decantada autonomía y descentralización, no pueden saldar sus presupuestos, teniendo todos grandísimos descubiertos y multitud de atenciones sin satisfacer; después de cobrado este nuevo, oneroso e indebido gravamen, se aplicaría a otras atenciones llamadas urgentes» ${ }^{142}$.

140. Arch. C.M., A.C., t. 71, 11-XI-1871, 16v.-17v.

141. Ibid., 24-II-1872, 6v. Para reforzar la presencia del arcediano en los despachos ministeriales, el obispo envía una segunda exposición al de Hacienda, volviendo a insistir en el estado doloroso en que se encuentra el clero de la diócesis, que muchos tendrían que abandonar sus cargos si esta situación se prolongase, que es una obligación pactada solemnemente (Constitución y concordato)... Cf. Circular 135. B.E.O.M., 26-IV-1872, 204-206. Sin embargo lo que más había influido en los despachos ministeriales había sido «la seguridad de que entre ellos (clero malagueño) no había habido ninguno que hubiera conspirado contra el Gobierno». Arch. C.M., A.C., t. 71, 12-IV-1872, 9v.-10v.

142. Cf. B.E.O.M., 7-XI-1872, 283-290. Antes de esta exposición ya habían enviado su protesta otros obispos reunidos en Zaragoza con motivo de las fiestas del Pilar. D. Esteban-José Pérez conocia el hecho y posiblemente el texto; quería hacer fuerza solidarizándose con sus hermanos del episcopado por medio de otro escrito en el mismo tono. Arch. C.M., A.C., t. 71, 23-X1872, 21v.-23. El proyecto no llegó a obtener la sanción de Amadeo I. 


\section{La primera República}

\section{Sucesos en Málaga}

A nivel oficial, la proclamación de la República es considerada como la culminación del proceso revolucionario iniciado en septiembre del 68 . El ciudadano alcalde Pedro Gómez así lo considera: ...«este hecho el más importante de la revolución española ha venido a destruir el último privilegio de nuestra organización política y realizar la democracia en las esferas del Estado" ${ }^{143}$. El pueblo entendía el hecho de otra manera: buen número de ciudadanos recorrían las calles con música, otros más tácticos ocuparon con armas ciertos lugares estratégicos y algunos - preventivos o provocadores - llegaron hasta los cuerpos de guardias y los desarmaron. Todavía quedaban unos pocos que decidieron tomar posesión de la Aduana y limpiar de papeles el archivo por el purificador sistema del fuego ${ }^{144}$.

El gobernador militar se dirige a los malagueños desde el castillo de Gibralfaro indicando que es leal a la República proclamada en las Cortes, exhorta a respetar personas y propiedades y recuerda -el hecho de hacerlo desde el castillo ya es significativo- que los jefes de su cuerpo están resueltos a sostener la autoridad. Tres días después, 15-II el ayuntamiento da el primer aviso de que todo debe volver a su cauce ${ }^{145}$. Sin embargo, Málaga había aprendido con relativa facilidad a protestar airadamente, a construir barricadas cuando no aceptaba algo, a decir no de forma poco pacífica... aún estaba reciente el motín de últimos de noviembre del $72^{146}$.

Al Presidente Figueras le preocupan los sucesos de Málaga y lo peor era que tomaban más cuerpo: desarme de soldados, nuevas barricadas; se aprovecha la presencia del capitán general Romualdo Palacio para intentar apaciguar al pueblo con pequeños atentados y unos cuantos disparos ${ }^{147}$. También ahora la República quiere consolidarse con apoyo del pueblo, que en el más cruel de los juicios, no apoya a nadie. Se organizan inmediatamente los volun-

143. Arch. Mp. M., A.C., 12-II-1873, 34v,-36v.

144. Arch. N.D. de E., leg. 305, carp. 4, 2.

145. ...«Hagamos ahora todos lo que nos corresponde, que es observar estrictamente los deberes que impone la dignidad de ciudadanos libres y habremos contribuido a la consolidación de nuestra nueva organización política, empezando por volver ya, desde hoy, cada uno a sus tareas habituales, toda vez que la libertad y el orden están asegurados y que lo más perentorio en la actualidad es que la población recobre por completo su estado normal y que los intereses de esta importante plaza mercantil no se resientan...) B.O.P.M., 15-II-1873, extraordinario.

146. Los sucesos habían sido netamente insurreccionales, con luchas callejeras, y la muerte del inspector del orden público. El gobernador militar tuvo que declarar el estado de guerra en toda la provincia e instar, en bando conminatorio, a que los vecinos y residentes en la capital depositaran las armas de fuego y blancas que posean en los cuarteles. El 30 de noviembre las tropas patrullaban por la ciudad y se daba por terminado el motín de turno. Arch. N.D. de E., leg. 305, carp. 3, 4-12. 
tarios que ahora son de la «república», para los que se piden armas y una comisión trasladada a Madrid consigue permiso para adquirir 4.000 fusiles ${ }^{148}$.

Málaga no se pacifica; el mismo gobernador civil, José Fantoni califica la situación de "graves momentos» ${ }^{149}$. A la salida del sol del día 8-VI los malagueños se preguntaron qué significaban los 33 cañonazos que habían escuchado a las baterías del castillo de Gibralfaro. Se celebraba la fausta noticia de que España se había constituido en República Democrática Federal ${ }^{150}$. El federalismo es interpretado en clave subjetiva y el caos y el desorden vuelven a la ciudad, ahora traídos de manos de unos de los batallones de los «voluntarios de la república»y y otras fuerzas que se les unen ${ }^{151}$. El castillo de Gibralfaro por ser sinónimo de servilismo y sumisión al gobierno central y porque es punto neurálgico para el dominio de la ciudad, estorba; en otras ocasiones se había tratado de su demolición, pero es ahora cuando se confirma.y sólo se espera a tener fondos para satisfacer los jornales. De todas formas al día siguiente se empezaría a bajar la artillería allí estacionada ${ }^{152}$.

Provisionalidad es la palabra que mejor puede definir estos meses. Todo tiene un aire de que no es definitivo y la conciencia de interinidad penetra en los órganos rectores de la vida local y provincial ${ }^{153}$. El miedo y la falta de seguridad son los frutos que antes y mejor llegan al pueblo que por no conocer los hilos del cañamazo donde se está bordando su porvenir, teme a todo y ante todo ${ }^{154}$.

147. Ibid., carps. 3, 4 y 5 .

148. Arch. Mp. M., A.C., 1-III-1873, 52. 12-III-1873, 60.

149. En consecuencia vengo en disponer: $1 .^{\circ}$, los «voluntarios de la república» formarán y vendrán a recibir las órdenes a este gobierno civil; $2 .^{\circ}$, el respeto a las personas y propiedades así como la paz pública y el cumplimiento de las leyes quedan bajo el amparo de los «voluntarios de la república» de esta ciudad. Málaga, 7-III-1873. B.O.P.M., 7-III-1873, extraordinario. Nuevamente se recuerda y recurre al «Bando del Buen Gobierno» el 30-IV-1873. Arch. N.D. de E., leg. 305 , carp. 4,10 .

150. Arch. Mp. M., 7-VI-1873, 110-110v. «Somos el primer pueblo de raza latina que intenta constituirse de esta manera... Procuremos consolidar la federación que hoy ha sido proclamada y que tantos sacrificios ha exigido del honrado pueblo de Málaga»B.O.P.M., 7-VI-1873. Y Francisco Solier, que en junio sería nombrado gobernador civil, se expresa así: «Ciudadanos, no queremos la república unitaria, porque no queremos dictadores; deseamos la federal, porque es el gobierno de todos para todos». Arch. N.D. de E., leg. 305, carp. 4, 12.

151. El comandante, jefes y batallón $n .^{\circ} 2$ quedan destituidos y disuelto, respectivamente. Todas las autoridades de la provincia proceden a su desarme y detención. B.O.P.M., 12-VII1873.

152. Arch. Mp. M., A.C., 8-VII-1873,141.

153. En los cinco primeros meses republicanos estos son los gobernadores civiles, provisionales, unos definitivos - y no es eufemismo- otros: Emigdio Santa María, José Fantoni Solís, Jesús Calvo Romeral, Santiago López Moreno y Francisco Solier. El ayuntamiento sigue por cauces parecidos: el 1-III renuncia la corporación, el 25-VI es asesinado el alcalde D. José Moreno Micó, el 7-VII es nombrado alcalde Eduardo Carvajal Reboul, el 8-VIl dimite el ayuntamiento... Arch. N.D. de E., leg. 305, carp. 4, 16.

154. El editorial de «El Folletín» 20-VII se titulaba «abuso de banderas», porque los 
Se anuncia que las tropas del general Pavía vienen a Málaga. El gobernador interino de turno dijo que esta situación era un lazo tendido o deseado por quienes pensaban que era indispensable la venida del general y que tomase cuerpo la idea de que no habría paz ni obediencia al Gobierno, mientras el pueblo estuviese armado ${ }^{155}$. Como en un crescendo sinfónico, los problemas que se planteaban a la República era el mismo tema, pero en clave individual para cada instrumento o grupo afín. El Gobierno de Madrid toma unas medidas que tratan de reorganizar y salvar lo que se ve sentenciado a un fin próximo. El ministro de Gobernación, E. Maisounave, lo comunica con urgencia al delegado del Poder Ejecutivo en Málaga, Esteban Ochoa, para su conocimiento y efectos ${ }^{156}$.

El golpe militar que pretendía un nuevo trasvase del Estado, esperando que éste fuese el definivito, intenta no caer en la tentación insurreccionista, popular e incontrolada, fácil y atractiva para tropezar en ella como se había demostrado en recientes ocasiones. El bando del gobernador militar, J. Carnicero no deja lugar a confusión: "Queda declarado el estado de guerra en esta plaza y provincia... se prohíben las agrupaciones sin armas y con ellas; queda prohibido el uso de armas hasta por individuos aislados aun cuando pertenezcan a las fuerzas populares... los reos de delitos de rebelión y sedición serán sujetos a un consejo de guerra que funcionará con arreglo a la ley de orden público de 23-IV-1873» ${ }^{157}$.

Con más tacto e indudable sentido político enfoca el alcalde Liborio García la alocución: «Malagueños, en nombre del orden social profundamente perturbado, en el nombre sagrado de la patria mutilada y agonizante, acudimos al llamamiento del Gobierno Nacional y aceptamos en momentos de suprema angustia y de peligro la administración del Municipio. Aquí estamos al frente de ella identificados con el Gobierno salvador del orden y de la Patria para cumplir fiel y exactamente con nuestros deberes. Nuestra misión es transitoria, pero grande, generosa y levantada. Venimos con la misión de hacer un

extranjeros residentes en Málaga -y debían ser bastantes para justificar el artículo y el contenido- hacían buen uso de ellas. Cuando llegaba un motivo preocupante en sentido político, ponían las banderas de sus respectivos países en sus casas para avisar a la población quiénes eran. El problema, según el editorialista, es que a veces parece como el engalanamiento de una calle para recibir a alguien importante, o un día de fiesta. Y eso se había extendido hasta llegar a calle Nueva, que siempre había sido neutral.

155. Arch. Mp. M., A.C., 20-VIII-1873, 209-211.

156. Restablecimiento de la ordenanza del ejército en todo su vigor; se suspenden las garantías constitucionales de la República; se establece la ley de orden público de 1870 en que se declaraban caducas todas las licencias de armas, se prescribía el uso de cédulas para viajar a todos los ciudadanos y se concedian medidas a los gobernadores para que sancionasen a la prensa que apoyáse cualquier tipo de insurrección. B.O.P.M., 22-IX-1873.

157. B.O.P.M., 4-I-1874, 6. Pocas horas después el gobernador civil presentaba la dimisión y le era admitida. Ibid., 7. 
municipio y administración, aquí donde el municipio dejó de ser hace tiempo y donde por desgracia ni existen ni hacienda ni administración local. Nuestros procedimientos para realizar esa grandiosa empresa serán enérgicos y decididos como cumple a hombres de carácter y abnegación completa, pero serán a la vez procedimientos de paz y concordia para inaugurar una nueva era de amplia base en que quepan todas las aspiraciones justas y en que se oigan todos los deseos legítimos. Para llevar a cabo esos propósitos por tan lícitos y prudentes medidas, interesamos el concurso de todas las clases de la sociedad y aspiramos a que unidos y compactos con ese sagrado objeto cada uno en su respectiva esfera facilitemos la obra emprendida por el Gobierno nacional de salvar el orden, la autoridad, la libertad y la república» ${ }^{158}$.

EI Presidente del Poder Ejecutivo en su manifiesto a la nación no quería olvidar o minusvalorar el poder y fuerza real de los católicos, que con demasiada rapidez y sin ninguna visión de futuro se había despreciado y ofendido en los años de la revolución ${ }^{159}$.

La guerra en las provincias del norte estaban ocasionando un derroche de vidas, dinero y tiempo, que España no podía mantener. Ahora se invoca el espíritu liberal, el sentimiento patriótico y celo popular de corporaciones y ciudadanos para «ayudar a la rápida conclusión de la guerra» con la aportación de un donativo ${ }^{160}$.

\section{Segunda expropiación de conventos}

El desarrollo de los acontecimientos religiosos y eclesiásticos seguía parejo a la marcha ascensional de los políticos, dentro del signo revolucionario del sexenio. A la vista de los hechos, la expropiación decretada y llevada a cabo en los primeros días de la «septembrina» fue como un ensayo general de los sucesos ocurridos en las calendas republicanas, pues desencadenaron uno de los hechos más revolucionarios de todo el sexenio en Málaga,

158. Arch. Mp. M., A.C., 9-I-1874, 7-7v.

159. ...«Menos aún deben recelar los buenos católicos y los hombres sinceramente religiosos. Ya ha cesado por dicha la corriente que en otras edades pudo llevarnos al protestantismo, y es fácil augurar que la libertad de cultos no ha de romper entre nosotros la unidad católica en las conciencias, antes ha de afirmarla y ennoblecerla, fundándola en una espontánea concordancia en la fe y no en la comprensión tiránica y en la violencia. El estado, pues, no puede desatender ni ofender a la Iglesia, desatendiendo y ofendiendo así a las creencias de la inmensa mayoría de los españoles y poniéndose en abierta lucha con una de las fuerzas más poderosas, persistentes y organizadas que encierra la sociedad en su seno..." B.O.P.M., 13-I-1874, 2.

160. Así se publica en Málaga el texto íntegro del ministro de la Gobernación. Cf. B.O.P.M., 2-III-1874, extraordinario. El ayuntamiento consciente de su responsabilidad inicia con 5.000 pts. una suscripción pública y voluntaria. Arch. Mp. M., A.C., 5-III-1874, 37-37v. Cinco meses depués la suscripción asciende a 84.561 reales y 32 cts. B.O.P.M., 8-VIII-1874. Desconocemos el total que aportó Málaga, porque durante el resto del año no hemos encontrado ningún ingreso nuevo ni alusión al tema. 
El 6-IV el obispo recibía un oficio del ayuntamiento solicitando permiso para que se llevase a cabo un reconocimiento en los edificios-conventos del Ángel, Carmelitas y Capuchinas, garantizando guardar las consiguientes conveniencias. La secretaría del obispado remitía el día 8 el correspondiente permiso y encargaba a tres arquitectos de la ciudad que emitiesen un informe certificado del reconocimiento de esos edificios ${ }^{161}$. Un mes más tarde el ayuntamiento era expeditivo en la resolución que daba sobre el convento del Ángel ${ }^{162}$.

En el mismo momento de la recepción del oficio, el obispo contesta al alcalde y corporación en la que le indica el resultado del informe certificado dictado por tres de los cinco arquitectos de la ciudad, le recuerda las disposiciones legales sobre esta materia y su forma de tramitarlas, que está dispuesto a reparar y repasar todo aquello que a juicio de los arquitectos municipales esté ruinoso... y también insiste en el dato humano de que trate de evitar un día de amargura y luto a la población malagueña ${ }^{163}$. Como el obispo había invocado al alcalde y a la corporación, se le contestó que habría que esperar a que ésta diese una respuesta, pero mientras tanto no debería hacerse obra alguna en el referido convento ${ }^{164}$.

La constitución de la República Democrática Federal vendría a trastocar profundamente el desarrollo de los acontecimientos. El esperado cambio de inquilino en el ayuntamiento puso un compás de espera que sólo era un electrizarse el ambiente para la tormenta que había de descargar en los días de verano y cuya primera detonación fue contundente. El 30 de junio se recibió este oficio en el palacio episcopal: «Acordados por el ayuntamiento de mi presidencia la demolición de todos los conventos de esta capital, espero dará V. las órdenes oportunas a fin de que en todo el día de mañana queden desalojados, para llevar a efecto dicho acuerdo. Esperando que tan luego como reciba V. la

161. Fue realizado por los Sres. Cirilo Salinas, Jerónimo Cuervo y Manuel Rivera, arquitectos de la Real Academia de Nobles Artes de S. Fernando: «El convento de Carmelitas está en un estado bueno de solidez y conservación; el de Capuchinas está en las mismas condiciones, y aún si cabe mejores; respecto al del Ángel no se puede decir en absoluto lo que de los anteriores, pues siendo el convento un agregado de diferentes casas particulares, afecta naturalmente a cada una de ellas un estado diferente de solidez y conservación. Málaga, 12 de abril de 1873». B.O.P.M., 1-VII-1873, 78-79.

162. «Del reconocimiento practicado por los arquitectos provincial y municipal resulta hallarse en muy mal estado el convento nombrado del Ángel, sito en la calle Granada de esta ciudad. Con este motivo y siendo preciso proceder al derribo para evitar las consecuencias de la ruina, suplico a V.E.I. tenga la bondad de adoptar las disposiciones que considere oportunas, a fin de que las religiosas allí establecidas dejen el citado edificio con la brevedad que el caso re-. quiere» B.E.O.M., 1-VII-1873, 79. Ya antes se había tratado del expediente de denuncia y se había acordado hacerlo en particular. Arch. Mp. M., A.C., 24-IV-1873, 103 v.

163. B.E.O.M., 1-VII-1873, 79-81.

164. Ibid., 81 . 
presente me dará aviso. Salud y República Federal. Nicolás Maroto. Ciudadano obispo de esta diócesis» ${ }^{165}$.

Según el mismo oficio lo exigía fue contestado inmediatamente. El obispo quiere dejar claro que nunca se ha opuesto a los mandatos de las autoridades, que tampoco está dispuesto a suscitar dificultades, aunque experimenta el dolor que le causa saber que muchas religiosas se quedarán en la calle. Dicta las órdenes oportunas a los conventos de la Trinidad, Catalinas, Císter y Encarnación, pero no a los de propiedad particular. Solicita con interés garantías y protección durante los traslados, para las personas y enseres, así como la ampliación del plazo ya que en un día no hay tiempo material de efectuar lo mandado ${ }^{166}$.

El cielo encapotado era el mejor síntoma de que la tormenta estaba en pleno desarrollo y era arriesgado predecir cuándo y cómo sería el fín. Un nuevo oficio de la alcaldía popular ponía en funcionamiento una nueva fase del proyecto: «Inspirado el ayuntamiento en el deseo de las grandes reformas que tanto necesita la noble y oprimida ciudad de Málaga, ha acordado oficiar a V. para que en el término de tres días abandone la casa-palacio que hoy ocupa, destinándose para el cabildo de la Soberanía popular, dedicando el edificio que tiene hoy (ex-convento de $\mathrm{S}$. Agustín), a escuelas de enseñanza. Lo que digo a V. con el objeto indicado. Salud y República Federal. Lorenzo Moniz. Ciudano obispo de esta diócesis»» ${ }^{167}$.

También fue contestado inmediatamente de esta forma: «aunque no creo que la opresión de esta noble ciudad consista en que el obispo habite una casapalacio; aunque tampoco creo que al lanzar de su morada al prelado de la diócesis constituya las grandes reformas que la municipalidad se propone y por más que el palacio que habito no pertenece al Estado, como me he propuesto no suscitar obstáculo alguno al municipio en prueba de amor entrañable que profeso a aquellos hijos que me afligen (...) Como el edificio que se me manda desalojar es de mi pertenencia y de los prelados que me sucedan, cuyos derechos no puedo perjudicar, a la vez que cumplo con lo acordado por el ayuntamiento, protesto contra el dicho acuerdo... Dios le bendiga como le

165. Ibid., 81-82. Ese mismo día se nombraba una comisión, que en unión del arquitecto, procediera al reconocimiento, tasación y derribo de los conventos. Arcin. Mp. M., A.C., 30-VI$1873,122 \mathrm{v}$.

166. Cf. B.E.O.M., 1-VII-1873, 82-83. Dentro de la precipitación de los hechos, el ayuntamiento concede de plazo hasta el día 2 para los conventos del Ángel y Carmelitas. En los conventos sólo quedarán las paredes; se hará un inventario y las monjas retirarán las cosas que les pertenezcan. Los cuadros e imágenes se depositarán donde diga el prelado. Será en la catedral, pero los cuadros y alhajas que pertenezcan al Estado se depositarán en la casa del pueblo. La corporación también acuerda reclamar el inventario de alhajas de la Iglesia formado en 1869. Arch. Mp. M., A.C., 30-VI-1873, 124-125.

167. B.E.O.M., 1-VII-1873, 84. 
bendice el obispo desde lo íntimo de su corazón en el día que V. le ordena salga de su casa" ${ }^{168}$.

En un último esfuerzo dentro de su enfermedad, agravada por el sufrimiento y las preocupaciones de esos días, D. Esteban-José Pérez se dispone a informar al ministro de Gracia y Justicia ese mismo día 1 de julio. El informe al ministro es más un grito de angustia ante la impotencia y un reiterar los̀ argumentos expuestos a los diferentes alcaldes que se suceden estrechando cada vez más el cerco de opresión, al tiempo que le comunica que por su quebrantada salud se retira a su pueblo dejando de gobernador eclesiástico el arcipreste de la catedral, D. Juan García Guerra ${ }^{169}$. Antes de partir, deja unas líneas de despedida a los fieles de la diócesis que son como la introducción que acompa-. ña al informe de esos acontecimientos y unos consejos pastorales para permanecer fieles al Señor en estos momentos de dura prueba y a obedecẹr en todo al gobernador eclesiástico ${ }^{170}$.

Los diversos oficios de desalojo e incautación de inmuebles religosos era el detonador de una serie de reacciones en cadena, difícil de preveer y más de evitar, porque totalmente incontroladas, pero planificadas, se desarrollan al amparo del miedo y de la presión que se pueden ejercer sobre pobres monjas que de momento se han convertido en la atracción de los acontecimientos ciudadanos y sobre todo que el río revuelto, confuso y urgente que supone el desalojo de un convento, es aprovechado por los pescadores oportunistas -que siempre los hay - a la captura de algo que merezca la pena por su valor material o artístico ${ }^{171}$.

168. Ibid., 84-85.

169. «Por la presente hago ante V.E., ante Dios, ante Málaga y ante los hombres, la más solemne protesta contra el derribo de los conventos reservándome para el día que pueda los derechos y acciones que procedan». Cf. Ibid., 83-84.

170. ...«Os confesamos que ese día ha sido para nosotros el de mayor aflicción y desconsuelo de nuestra vida, y tal desengaño aumenta nuestro pesar porque amamos con todo nuestro corazón a esos hijos seducidos y engañados por una errónea creencia de que tal vez hacen algún bien a sus semejantes, sin comprender los irreparables y funestos males que ocasionan... No os dejéis seducir ni engañar del error y la impiedad, que permanezcáis firmes en la fe, que redobléis vuestras oraciones... que prestéis obediencia al gobernador eclesiástico que dejamos durante nuestra ausencia». B.E.O.M., 1-VII-1873, 87.

171. En el desalojo del convento de Carmelitas desaparecen dos candelabros de plata. Se dan órdenes para que nadie más que los presuntos compradores y sus peritos pasen a los conventos y el pueblo debe respetar a los centinelas. Arch. Mp. M., A.C., 2-VII-1873, 128. Se pregunta por el paradero de la custodia del convento del Ángel y sin responder nada concreto se dice que está guardada. Ibid., $128 \mathrm{v}$. Se manda retirar de las calles toda imagen sagrada ya que el culto se debe dar en los templos o en el interior de las casas particulares. Ibid., 4-VII-1873, 135. Se propone por moción del ciudadano Pedro Giner la demolición de la Iglesia del Sagrario. Ibid., 5-VIII$1873,136 \mathrm{v}$. Ante el problema humano - ya había insistido en él el obispo- de que las religiosas pobres, mayores y sin auxilio de familias quedaban real y auténticamente en la calle, se les concede que pasen al Hospital Noble ya que allí podrían ser útiles. Ibid., 5-VII-1873, 138v. 
Según se procedía al desalojo del palacio episcopal y quizá para evitar el trastorno y trabajo de la operación, la municipalidad pensó otro medio más efectivo y rápido. Se presentó en el lugar de autos una comisión incautándose del archivo general y de la biblioteca episcopal — de donde aún no se había tocado ni sacado legajos ni libros- así como de papeles y expedientes de la secretaría de cámara y de efectos mobiliarios del palacio y sus dependencias ${ }^{172}$. Es el bautizo de fuego del gobernador eclesiástico; no se puede hacer nada. La única fórmula es el testimonio de protesta para que alguna vez se pueda saber ${ }^{173}$. Ese mismo día y acto seguido escribe al alcalde protestando de que ya ni siquiera cumplan con lo que ordenan los oficios, ni en la forma ni en el contenido ${ }^{174}$.

Aunque el ayuntamiento había putlicado y otorgado por aceptación los pliegos y condiciones para el derribo de los conventos, hay un cambio de orientación consistente en que la Administración será la que derribe los conventos para que los obreros que participen puedan obtener mejores beneficios que de la otra forma quedarian en manos de los contratistas, respetando los contratos ya realizados con los particulares ${ }^{175}$.

Hasta el 7 de julio el ministerio no acusa recibo de la comunicación del obispo en términos respetuosos, pero poco efectivos, posiblemente porque 'era cierto que no podía hacer nada. De todas formas, es una gran victoria y una ventana que se abre a la esperanza ${ }^{176}$.

Ese mismo día la Corporación Municipal elegía nuevo alcalde -D.

172. Arch. Mp. M., A.C., 4-VII-1873, $135 \mathrm{v}$.

173. A ella recurre D. Juan García Guerra. Se trata de escribir al ministerio de Gracia y Justicia en descargo y testimonio...: «cumplo con el deber de hacer formal protesta de esos hechos ante V.E. declinando toda responsabilidad si el día de mañana faltara alguna cosa del archivo, biblioteca o de la secretaría de cámara y con el fin de que V.E. tenga exacto conocimiento de todas las comunicaciones, adjunto le envío el boletín eclesiástico donde constan». C. B.E.O.M., 10-VII-1873, 89-91.

174. «Habiendo ofrecido y garantizado que el municipio no se incautaría más que de las paredes de los monasterios y que todos los objetos destinados para el culto y demás efectos serían puestos a disposición de la autoridad eclesiástica y habiendo entendido que muchas imágenes y otros objetos se están depositando en la casa que la municipalidad ocupa y en la de algunos señores de la corporación, me dirijo a V.S. rogándole que tenga la bondad de ordenar se pongan a mi disposición todas las pinturas, esculturas y demás efectos que por todos los títulos deben estar a disposición de la autoridad eclesiástica. No dudo que así lo acordará... más si así no fuere, no puedo menos de formular la debida protesta, reservándome hacer uso en su día de las acciones que competen ejercitar a la autoridad eclesiástica». B.E.O.M., 10-VII-1871, 91.

175. Arch. Mp. M., A.C., 4-VII-1873, 134v. 8-VII-1873, 140v.-141.

176. ...«El Gobierno de la República ajeno a las disposiciones de ese municipio comprende y lamenta los disgustos... se halla dispuesto a remediarlos en cuanto le sea posible, dictando las órdenes que el caso requiere y aprueba, estima y aprecia en todo, lo mucho que vale la prudente conducta observada por V.E. que desea recomiende a su gobernador eclesiástico durante su ausencia y mientras por parte del gobierno se procura sean reparados los legítimos derechos de la Iglesia». B.E.O.M., 10-VII-1873, 93. 
Eduardo Carvajal Reboul - con lo que esto ocasionaba de estancamiento porque tenía que informarse del asunto y el gober nador eclesiástico debería esperar a ver la postura que tomaba ante el problema. La contestación del ministerio - y su contenido - es una oportunidad inmejorable en sus manos para sondear a la autoridad municipal. El gobernador transcribe la contestación ministerial añadiéndole unas sugerencias propias ${ }^{177}$.

La República Federal se encontraba en su marasmo cantonal y en Málaga el proceso adquiría por momentos tintes revolucionarios. Las secciones obreras solicitan a la corporación que les cedan el convento de Carmelitas u otro para celebrar sus reuniones y establecer un centro de instrucción ${ }^{178}$.

La Corporación Municipal puesta al día sobre las enajenaciones eclesiásticas clarifica su postura confirmando los acuerdos del ayuntamiento anterior de que sean derribados todos los conventos que no sean propiedad particular. Los conventos propuestos para derribar son los del Ángel, Beaterio del Carmen, Capuchinos, Encarnación y Císter, e inmediatamente se pasa a adjudicar las obras ${ }^{179}$.

Mientras, el ayuntamiento había reconocido la propiedad eclesiástica de las imágenes de los conventos y se las había entregado al gobernador eclesiástico, que inmediatamente remite un oficio agradeciendo el gesto, ya que esperaba el más pequeño atisbo de buena voluntad por parte de la Corporación Municipal para ver si aún se podía poner remedio a tanto mal. Aprovechando ese gesto remite un nuevo oficio para que se le entreguen los objetos de culto ${ }^{180}$. El proceso de desalojo y derribo de conventos sigue su marcha y la desaparición de objetos, también ${ }^{181}$.

177. «Le ruego se digne suspender y dejar sin efecto los acuerdos del anterior municipio sobre la subasta, demolición o enajenación de los convenios hasta que las Cortes constituyentes y el Gobierno de la República adopten las disposiçiones que procedan con arreglo a justicia y derecho... Reclamo a V.S. la oportuna constestación al oficio del 5-VII que dirigí a su antecesor para que fueran puestos a mi disposición las imágenes y efectos procedentes de los conventos desalojados...» B.E.O.M., 10-VII-1873, 94.

178. Se accede a la petición y se les concede el convento de Capuchinas. Arch. Mp.M., A.C., 9-VII-1873, 145.

179. Se recurre nuevamente al argumento ya empleado en la expropiación de conventos del año 1868, de que esta medida servía para fomentar el trabajo de las clases jornaleras en paro. Arch. Mp. M., A.C., 15-VII-1873, 151. 16-VII-1873, 154v. Las del convento del Ángel se conceden a D. Esteban Hisarre en 12.577 pesetas. Ibid.

180. Ibid., 8-VIII-1873, 182v. Se le contesta que respecto a los cuadros y demás enseres no se puede hacer lo mismo a no ser que sean de propiedad particular. Ibid., 13-VIII-1873, 195v.196. Entonces había que presentar los títulos de legítima propiedad a la comisión de derribos y esperar el fallo.

181. Ahora le toca el turno a dos cuadros del convento de la Encarnación que se hallaban ubicados en la parte alta del retablo, al parecer de valor por las habladurías que corren por la ciudad y la serie de veces que se citan en las sesiones de la corporación municipal. Ibid., 8-VIII1873, 184. 9-VIII-1873, 187. También el contratista del derribo del Beaterio del Carmen, D. Ma- 
El 18-VIII llega la primera decisión oficial del gobierno al ayuntamiento, añadiendo un nuevo matiz de complicación y demasiado tarde para pretender ser eficaz. La Administración Económica de Málaga recibe un telegrama remitido por la Dirección General de Propiedades para que lo pase al ayuntamiento popular de la ciudad: «Proteste V.S. en nombre del Estado por los derribos de conventos acordados por el ayuntamiento y suspenda o impida llevarlos a efecto demandando el auxilio de las autoridades»" ${ }^{182}$. El ayuntamiento decide tratar inmediatamente el asunto para remitir una contestación, que por lógica no sorprende. Es imposible suspender la marcha de los derribos porque están hechos los contratos y los concesionarios ya han entregado algunos plazos, porque los derribos están casi concluidos y que esto ha contribuido a paliar la miseria de las clases proletarias en la crisis de trabajo. La votación efectuada era contundente: 17 ediles eran partidarios de continuar las obras y 2 de que se suspendieran ${ }^{183}$.

La supresión de las Cortes hasta el 2 de enero y las medidas del restablecimiento de la ordenanza del ejército, la ley de Orden Público de 1870, la supresión de garantías constitucionales, de licencias de armas, la necesidad de cédulas para viajes, etc., implantadas el 22 de septiembre era una medida tardía del Gobierno Central para hacerse con las riendas y el dominio de la fiera que estaba desbocada. Sorprendió el giro que daban las cosas en un primer momento cuando el delegado del Poder Ejecutivo en la provincia comunicaba al ayuntamiento una resolución en estos términos: «A fin de poder hacer entrega del Palacio episcopal a D. José Rubio, representante del obispo de la diócesis, se servirá $\mathrm{V}$. dar las órdenes oportunas para que a la mayor brevedad posible se retiren de dicho palacio todos los objetos pertenecientes al ayuntamiento" ${ }^{184}$. Con este oficio se inauguraba una nueva marcha, confirmada cuando el Jefe Económico de la provincia recibe órdenes de incautarse en nombre del Estado de cuantos bienes le corresponden y se hallen fuera de la Administración y transmite a la Corporación que como se ha hecho cargo de los conventos, cuanto existía en los edificios y contratado sus derribos, «me dirijo a Vd. para que dé órdenes de que se ingresen en las arcas del Tesoro el valor de los remates de los derribos y de los efectos que se han enajenado" ${ }^{185}$.

nuel Rodríguez Mare, expone haber encontrado de menos varias puertas y otros efectos en el citado edificio. Ibid., 13-VIII-1873, 192v.

182. Ibid., 19-VIII-1873, 205-206.

183. Ibid., 19-VIII-1873, 206v. En un acto de no acatar ningún otro criterio que el del 'ayuntamiento popular, en esa misma sesión se acuerda convocar por edicto para el próximo domingo, día 21 a las doce, pública subasta de los cuadros de los conventos, previa tasación. Ibid., 207.

184. Ibid., 24-IX-1873, 253v. El proceso de los otros edificios sigue su marcha de derribo y colocación, donación o pérdida de sus pertenencias en otros lugares. Se concede a la barriada del Palo y a la parroquia de S. Pedro de Málaga sendas campanas provenientes de los coríventos derribados. Ibid., 27-IX-1873, 238.

185. Ibid., 30-X-1873, 312v.-314v. 
El problema pasa a depender oficialmente del Estado en el momento que se confirma que la Administración Económica se ha incautado de los «conventos derribados como están» ${ }^{186}$.

El nuevo estado de cosas sólo abría interrogantes. De momento había que empezar otra vez el proceso de comunicaciones al ministerio o al mismo Presidente. Desde Loja, donde aún está residiendo, el obispo malagueño envía una detallada exposición al ministro de Gracia y Justicia recordándole la ya remitida el pasado 1 de julio, en términos parecidos $y$, tratando de curarse en salud, le previene con mucho tacto de que el gobierno no tropiece en la misma piedra que el Municipio ${ }^{187}$.

Aprovechando también el pequeño resquicio de que el Estado se había incautado de los solares, la Comunidad del convento del Ángel remite una exposición al Presidente del Poder Ejecutivo haciendo breve historia de la situación y mostrando sus legítimos derechos sobre el solar y lo poco que ya queda del convento. Insiste en los derechos fundamentales de la Constitución -arts. 13, 14, 17 y 21- que se han violado en este asunto y en el título legítimo de propiedad, así como en el abuso de facultades de la Corporación Municipal ${ }^{188}$.

Nuevamente lós acontecimientos políticos de enero abrían un paréntesis de espera sazonado con unos muy escasos granos de ilusión, por lo que se deducía del discurso del general Serrano, cuando afirmaba: «El Estado, pues, no puede desatender ni ofender a la Iglesia, desatendiendo y ofendiendo así a las creencias de la inmensa mayoría de los españoles» ${ }^{189}$. En vista de estas declaraciones que permitían un leve optimismo, también interviene el cabildo catedralicio en el problema, primero, manifestando su público dolor por ver destruidos y arrebatados nuevamente los conventos e iglesias de Málaga y después decide enviar una exposición al Presidente del Poder Ejecutivo para que devuelva los solares de los conventos a sus respectivos propietarios ${ }^{190}$.

El tema de los conventos - los solares - entra en vía muerta. Se había convertido en una piedra de tropiezo para muchas autoridades. Hasta últimos del año 74 no volvemos a tener noticias. El 16 de noviembre el secretario de la Presidencia de la República comunica a través del gobernador que el día 8 de ese mismo mes pasó al ministerio de Hacienda la instancia del ayuntamiento en solicitud de que sean devueltos al diocesano los solares de los conventos

186. El Decreto del Poder Ejecutivo databa del 17-X. Ibid., 20-XI-1873, 346v.- 347.

187. Cf. B.E.O.M., 26-XI-1873, 119-120. Semejantes argumentos son empleados también por el gobernador eclesiástico en su comunicación a los Sres. Presidentes del Poder Ejecutivo y Jefe económico de la provincia. Cf. B.E.O.M., 16-I-1874, 137-138.

188. Cf. B.E.O.M., 15-XII-1873, 122-126.

189. B.E.O.M., 13-I-1874,2.

190. Arch. C.M., A.C., t. 71, 27-I-1874, 2v'.-4. Ibid., leg. 706, sin numerar. 
derribados y la de que se le ceda al ayuntamiento el solar del convento de la Encarnación para construir un mercado ${ }^{191}$.

Hasta la Restauración de D. Alfonso XII el problema de estas incautaciones y enajenaciones de bienes eclesiásticos y artísticos no encontrarán una solución definitiva en los llamados decretos de «reparación» de 9-I-1875.

\section{Problemas económicos del clero}

En abril de 1872, a los veintitrés meses de no percibir la dotación, el Estado decide satisfacer los atrasos en billetes del Tesoro, pero no clarifica cuál será el futuro de la dotación y la forma de cobrarla. Ante una solución parcial cabría esperar que dentro de poco surgiera con idéntica fuerza el eterno problema. Ya habían pasado otros quince meses desde que se prometiera el pago y aún no se había hecho efectivo el dinero, lo que suponía un atraso real en el cobro de la dotación de treinta y ocho meses.

En agosto de 1873 al cabildo le preocupa la situación del culto y personal de la catedral y nombra una comisión que estudie el asunto. El informe insiste en tres puntos ${ }^{192}: 1 .^{\circ}$ ) teme que desaparezca la plata, lo que providencialmente aún no ha ocurrido; con permiso del Prelado se puede vender algo para sostener al personal. $2 .^{\circ}$ ) Recurrir nuevamente a la piedad de los fieles por medio de unas suscripciones voluntarias, como se había hecho en 1870 , pero el cabildo constata también un hecho sociológico importante: «a pesar de la ausencia de muchos vecinos acomodados», o como el mismo obispo había indicado en su exposición al gobierno cuando la expropiación del palacio y conventos: «sólo el obispo ha estado en su puesto inspirando confianza con su presencia, cuando emigraban muchos de sus vecinos». No esperan tener tan buena acogida como antaño. $3 .^{\circ}$ ) El clero y personal de la catedral no puede soportar humanamente la situación. Una vez que sea proclamada la separación de la Iglesia y el Estado pierden toda esperanza de ser retribuidos en sus legítimas dotaciones y el proyecto de una nueva constitución ya se estaba discutiendo en las Cortes. En él se proclamaba esta separación. Además, parte del clero catedral se había ausentado de la capital para «buscar en otra parte el simple cubierto»" ${ }^{193}$.

El obispo concede que se apliquen misas a intención de las capellanías mientras los fondos lo permitan, pero teniendo en cuenta de que «esas medidas no son suficientes», deciden recurrir a la piedad de los fieles por medio de suscripciones ${ }^{194}$. La comisión ha preparado un borrador de circular para imprimirla y enviarla a las casas, pero se acuerda no llevar a término la impre-

191. Arch. Mp. M., A.C., 16-XI-1874, 175.

192. Arch. C.M., A.C., t. 71, 9-VIII-1873, 20v.-23. 11-VIII-1873, 23-26v.

193, Ibid., 11-VIII-1873, 260v.

194. Ibid., $26-\mathrm{IX}-1873,33 \mathrm{v}$. 
sión dada la situación económica que todos experimentan y para darle publicidad se decide invitar a los directores de los periódicos para que a través de sus medios de difusión hicieran conocer al pueblo la apurada y triste situación en que se encuentran ${ }^{195}$. La distribución de los fondos recaudados se hará según sistema proporcional en el mes de enero ${ }^{196}$; por vía de socorro y orden de clases en los meses de febrero y marzo y por categorías y según asistencia, a partir de abril ${ }^{197}$.

En un rápido balance realizado por la comisión se comprueba que el ingreso de las suscripciones disminuye, aunque también hay que incluir en los fondos el dinero obtenido por la venta de algunos objetos de plata y algunas campanas. De lo recogido se podrá dedicar dos tercios al culto y un tercio al personal ${ }^{198}$. De julio a diciembre de 1874 se recaudan por concepto de suscripciones 33.495 reales. Hay que descontar el mes de agosto del que nosotros no hemos encontrado ninguna referencia en el archivo catedralicio ${ }^{199}$.

El 15-I-1875 el nuevo Régimen trataba de solucionar este problema con un decreto sobre la dotación del culto y clero. Se comprometía a satisfacer los atrasos no abonados, una vez determinados su importe y la forma de hacerlo ${ }^{200}$. El sexenio no había dejado las arcas del Tesoro en buen estado;

195. Ibid., 1-X-1873, 34-35. 22-X-1873, 35-36.

196. Ibid., 10-III-1874, 6-7.

197. Ibid., 23-III-1874, 7v.-8. El tema de la asistencia a coro y demás actos litúrgicos se había tratado y debatido ampliamente durante estos años, porque las ausencias había que sustituirlas y cada vez eran más numerosas y continuas las irresidencias de la capital, que en algunos casos eran motivadas sencillarnente porque buscaban en otros lugares algunas actividades religioso-pastorales de las que pudiesen vivir. El libro «del punto» refleja la resistencia, las ausencias voluntarias, las justificadas y las vacaciones. Por eso se indica ahora que en el reparto de los donativos se debe tener presente este aspecto.

198. Ibid., 17-VI-1874, 13v.-14.

199. Podemos establecer el siguiente cuadro indicador de los meses, número de suscripciones y total recaudado:

\begin{tabular}{lcc} 
MESES & SUSCRIPTORES & REALES \\
- Julio & 412 & 7.035 \\
-Agosto & $(?)$ & $(?)$ \\
-Septiembre & 385 & 6.347 \\
-Octubre & 381 & 6.981 \\
- Noviembre & 379 & 6.709 \\
-Diciembre & 351 & 6.423 \\
& & - \\
\hline
\end{tabular}

Arch. C.M., leg. 706, sin numerar.

200. «El Gobierno de S.M. aspira a reparar las lesiones que las turbulencias de los últimos tiempos hayan causado, a patentizar que ninguna obligación ha de quedar desconocida u olvidada... sin poner en duda o litigio los compromisos contraídos a nombre de la nación por los poderes que se han sucedido en el Gobierno... las asignaciones del clero no eran retribución de una función administrativa, sino compensación de antiguos derechos y propiedades que la lglesia había cedido al Estado». Cf. B.E.O.M., 27-I-1875, 224-227. 
claro, que tampoco las había encontrado repletas. Ahora la intermitente guerra carlista aparecía de nuevo y también era necesario un presupuesto especial. El clero, como en otras ocasiones, cedería de su dotación por varios años, un $25 \%$ para enjugar la falta crónica de reservas con qué hacer frente a los presupuestos ordinarios - generales - y a los extraordinarios - la guerra- ${ }^{201}$.

\section{Temas religiosos y pastorales}

Los grandes temas vertebrales del pontificado malagueño de D. EstebanJosé Pérez Martínez estuvieron condicionados ineludiblemente por los acontecimientos sociopolíticos nacionales y provinciales que en su faceta legislativa y de acomodación de todas las estructuras a la nueva realidad del país incidieron en temas y aspectos en los que la iglesia había sido durante demasiado tiempo la única dueña y señora.

Muchos obispos - peso específico en la Iglesia española por el número y cargo- optaron en bloque o en particular, pero siempre al unísono, por cargar el peso de su poder, la eficacia de su fuerza y la dignidad de su responsabilidad en la lucha contra viento y marea de mantener el mismo «statu quo» de privilegio y primacía para una determinada confesión religiosa, es cierto que absolutamente mayoritaria, al menos a niveles estadísticos oficiales, como es la recepción de los sacramentos.

En vez de orientar, marcar y enseñar la postura de la concepción cristiana de la vida para regir y santificar a sus seguidores, se abrogaron la responsabilidad de catequizar a los que por tibieza, anticlericalismo, ilustración o herejía no querían permanecer en el único aprisco y bajo las órdenes de un único pastor.

Es cierto que nuestro obispo tuvo márgenes de tiempo para marcar su impronta en las grandes directrices de la pastoral de la diócesis, pero siempre con la mirada vigilante y los oídos atentos a las noticias de los proyectos que se discutían en las Cortes o los artículos que la fecunda prensa del último tercio del siglo XIX insertaba en sus páginas.

\section{Matrimonio civil}

El 15-XII-1869 el ministro de Gracia y Justicia, Montero Ríos, presenta a las Cortes para su discusión un proyecto sobre matrimonio civil. Desde los primeros momentos de su presentación los sectores más conservadores del país lo acogieron con hostilidad por el hecho de que era un salto -esta vez cualitativo- dentro del proceso secularizador que al parecer se había marca-

201. B.E.O.M., 19-VIII-1876, 109-111. 2-VIII-1877, 19 '6. 
do la revolución de septiembre del 68. Otros lo consideraron como una traición con premeditación y alevosía ya que se aprovechaba la coyuntura de que casi dos tercios de obispos estaban fuera de sus diócesis asistiendo en Roma a las sesiones conciliares y, en este tema como en tantos otros, sólo se veía el aspecto religioso de que el vínculo matrimonial era por ley natural uno, único e indisoluble ${ }^{202}$.

En Málaga la corporación municipal adelantándose bastantes meses al proyecto del Gobierno, ya había tratado el tema con un respaldo notable de los concejales ${ }^{203}$.

A Roma ha llegado la noticia del proyecto y los obispos no demoran su primera respuesta colectiva que, en forma de carta, dirigen a las Cortes constituyentes el 1-I-1870 ${ }^{204}$. Cuenta con cuarenta y una firmas de los obispos que están asistiendo a las sesiones conciliares. Muchos obispos preparaban una exposición particular para remitir a las Cortes, pero «como todos los obispos españoles nos reunimos en casa del Sr. Cardenal Arzobispo de Valladolid para tratar en particular los asuntos de España», según afirmaba el arzobispo Claret ${ }^{205}$, allí surgiría la idea de unir todos los borradores en una única carta. También es colectivo este documento, porque en los escritos de los demás obispos que han quedado en sus diócesis, y que también envían a las Cortes, se solidarizan con el documento de Roma y muestran su total unanimidad con los argumentos allí expuestos.

Estas son las ideas y principales argumentos del escrito colectivo: la lectura de este documento - el anteproyecto- les ha llenado de asombro, ha producido en sus corazones la más honda y profunda amargura. El proceso que se pretende es contradictorio a la índole y el carácter religioso de los españoles. Estimulados por el interés hacia la patria ruegan que desechen el proyecto, porque:

-Es anticatólico.

-Es inconciliable con la moral y el dogma de la Iglesia.

-No es de la competencia del poder civil.

- Sería un atentado para destruir la familia tradicional.

- Sin llevar ninguna ventaja, ofrece inconvenientes políticos ${ }^{206}$.

202. El arzobispo de Santiago, cardenal García y Cuesta, ve que no es posible la distinción entre ciudadano y cristiano, porque son dos aspectos de la misma realidad y no dos realidades distintas; además el matrimonio civil sería en un país católico, un torpe amancebamiento o concubinato legal y la ley que esto protegiese, lejos de ser ventajosa para la nación sería antipolítica. ROdriguez DE CORO, F., El obispado... o.c., 142-143.

203. Primero se había propuesto la creación del registro civil como base imprescindible de trabajo para un estado moderno. Arch. Mp. M., A.C., 8-1I-1869, 43v.-44. La proposición de establecer el matrimonio civil es respaldada por los alcaldes $2 .^{\circ}, 4 .^{\circ}, 7 .^{\circ}, 9 .^{\circ}$ y el $6 .^{\circ}$ accidental y por 11 concejales más. Ibid., 11-III-1869, 87v.

204. B.E.O.M., 28-I-1870, 335-340.

205. San Antonio María Claret, Escritos..., o.c., 478-479.

206. «El matrimonio civil jamás entre católicos será otra cosa que un inmoral concubinato 
El 27 de mayo es aprobado el proyecto, fijando el próximo 1 de septiembre como fecha para entrar en vigor. Muchos obispos aprovechan la vuelta del concilio - clausurado «sine die» por los asuntos políticos del Gobierno italiano- y el tiempo de la «vacatio legis» para acomodarse a las circunstancias del momento, dar normas pastorales a sus respectivos párrocos y orientar a los fieles acerca del valor sacramental que el matrimonio tiene entre los cristianos ${ }^{207}$.

El obispo de Málaga como firmante de la carta colectiva a las Cortes, ahora de regreso en su sede escribe una circular al clero y fieles donde intenta exponer una serie de argumentos teóricos - compendio del escrito a las Cortes-y práctico - resumen de cómo debe actuar el cristiano- ${ }^{208}$.

La ley del matrimonio civil no había legislado nada contra el significado y contenido de la celebración de matrimonios canónicos. Sólo aceptaba la posibilidad - y para esos casos legislaba - de que en España hubiese parejas que, de acuerdo con sus conciencias, no quisieran aceptar el sacramento como sello de su unión matrimonial.

En una nueva circular el prelado malagueño vuelve a exhortar sobre el valor de los matrimonios y el significado de cada uno de los ritos ${ }^{209}$; en los primeros meses de vigencia de la ley en la diócesis de Málaga hubo una cierta

o un escandaloso incesto; ni la autoridad legislativa o gubernativa podrán sacarlo nunca de su inmoral y escandalosa condición (...) Antes de existir sociedad alguna existió el matrimonio como contrato natural cuyos deberes y derechos fueron delimitados por el Creador y más tarde, en la ley de la gracia, explicados y perfeccionados en el mismo evangelio por el mismo Hijo de Dios (...) Esperamos que lo desecharán por el bien de nuestra patria (...) En los prelados españoles existe la decidida voluntad de dar al César lo que es del César, pero siempre sin perjuicio de dar a Dios lo que es suyo». Cf. IribarRen, J., Documentos colectivos del episcopado español (1870-1974). B.A.C.- Madrid 1974, 61-66.

207. Por ejemplo, puede verse la circular de Alguacil y Rodríguez, obispo de Vitoria en B.E.O.V., 20-VIII-1870. Cf. RodríGuez DE CORO, F., El Obispado... o.c., 143-144. También en el mismo sentido, los obispos de Orihuela, Cubero López y el de Almería, Rosales Muñoz. Cf. VILAR, J.B., El obispado de Cartagena durante el sexenio revolucionario (1868-1874). Murcia, 1973, 27.

208. «La familia es la base de la sociedad y lo mismo el sacramento que forma la familia (...) Por el sacramento del matrimonio dejó el padre de ser un déspota, porque la paternidad cristiana le hace partícipe de la autoridad del Creador y de su caridad inagotable... la madre dejó de ser esclava al ser declarada compañera con los mismos derechos... el hijo dejó de ser víctima para ser hijo de Dios y hermano de Cristo (...) Entre cristianos no puede contraerse matrimonio sin sacramento; cualquier otra unión será concubinato...» Cf. Circular 111, B.E.O.M., 26-VIII$1870,419-422$.

209. Cf. Circular 121, B.E.O.M., 4-II-1871, 479-486. Señala unas notas pastorales que merecen la pena tener en cuenta: Apela a la conciencia, santuario religioso, para el obedecimiento a los poderes civiles. Delimita con precisión el campo de dos competencias jurídicas distintas, aunque incidiesen en un único sujeto, que era a un mismo tiempo súbdito del Estado y fiel de una confesión religiosa. El hacer ver que estas dos militancias no se contraponen. El carácter de perpetuo perdón de la Iglesia. El hacer gratis los trámites del matrimonio canónico a los más necesitados. 
afluencia -dentro siempre de su carácter minoritario- a contraer únicamente matrimonio civil, en parte por el atractivo que representaba esta ley novedosa.

No hay que olvidar que el proceso revolucionario no se quedó contento con declarar como único matrimonio válido ante el Estado, el efectuado ante un juez municipal, sino que «llegó el fanatismo hasta declarar por decreto, el 11-I-1872, hijos naturales a los habidos en matrimonio canónico» ${ }^{210}$.

Una conclusión en el terreno de la pastoral práctica y que derivó en un fuerte encontronazo diócesis-Gobierno, obispo-ministro, vino como consecuencia de no dar significación, por ignorancia o error y, en no pocos casos por tozudez, a los sacramentos del matrimonio y del bautismo. No eran meros ritos como desgraciadamente se les había tomado durante mucho tiempo sin profundizar en su contenido a nivel de exigencias concretas para la vida. La libertad de cultos fue un aldabonazo para que se ahondara en lo que significaba creer, vivirlo en el plano de la conciencia y confesarlo públicamente.

Intentando resumirlo, conservando la fidelidad a los hechos, así fue lo que ocurrió y como se desarrollaron los acontecimientos. Del ministro de Gracia y Justicia llegó esta comunicación al obispo de Málaga: «Habiendo acudido a este ministerio el 11-IX-1872 el alcalde de Benaocaz en queja del párroco por negarse a aceptar como padrinos en el bautizo de un niño a dos personas enlazadas por el matrimonio civil solamente; como quiera que ni el rigorismo de los principios del derecho canónico, ni los de la más timorata conciencia, autorizan la oposición del párroco, el rey (Q.D.G.) se ha servido disponer ordene V.E. a este eclesiástico que evite en lo sucesivo motivos injustificados de colisión y de lucha con la potestad temporal, y no traspase, como en el presente caso, los limites y línea de conducta que los venerables prelados y doctores de la Iglesia han trazado a los ministros evangélicos. De Real Orden lo digo a V.E. a los fines oportunos. Madrid, 15 de octubre de 1872» ${ }^{211}$.

Una semana más tarde - 22 de octubre - contestaba el obispo al ministro una carta en términos comedidos y acudiendo a las verdaderas raíces del problema ${ }^{212}$. Reconocía en el ministro grandes dotes de rectitud. Él sabía dar al César lo que era del César, sin embargo también era una obligación dar a Dios lo que es de Dios y no podía prescindir de atenerse a las leyes divinas de la Iglesia, es decir, que enseñando y mandando la Iglesia que los casados sólo civilmente no podían ser padrinos de bautismo, no podía de ninguna manera encargarse de cumplir la orden que le comunicaba.

La prensa religiosa contestaba bastante más violentamente al ministro a

210. Menéndez Pelayo, M., Antología General, presentada por J.M. ${ }^{\text {a }}$ Sánchez de Muniáin. B.A.C.- Madrid 1956, 921.

211. B.E.O.M., 12-XII-1872, 292.

212. Ibid., 295-296. 
quien se otorgaba la paternidad del proyecto de matrimonio civil ${ }^{213}$. El ministro no aceptó las razones del prelado malagueño y nuevamente le escribe el 8 de noviembre en términos que querían ser la conclusión definitiva del caso ${ }^{214}$. Nuevamente es la revista eclesiástica la que sale en defensa de la Iglesia católica en esta intromisión, sin razón justificada, del poder temporal en lo específicamente religioso ${ }^{215}$.

Todavía a finales del año 1874 el obispo Pérez Martínez continúa insistiendo a los párrocos y sacerdotes sobre el sacramento del matrimonio. Una de las razones que le han hecho no olvidarse del asunto es «que muchos fieles

213. Se publicó en la revista religiosa «el consultor de párrocos». No podemos dar más detalles de autor y fecha, porque nos hemos basado en lo publicado por el boletín diocesano. Según la revista se cometen varios atentados: "Negando a la Iglesia su autoridad y libertad - art. 21 de la Constitución - ordena y manda a los obispos como si en lo eclesiástico fuesen subordinados (...) ¿Con qué derecho se queja un alcalde de un párroco? Si ha faltado a las leyes que lo denuncie a los tribunales y si el alcalde se queja sin razón y contra derecho, ¿por qué admite su queja el Gobierno? (...) El Gobierno tiene la osadía de dar una orden al obispo, como pudiera darla al gobernador civil tratándose de un asunto político. Se trata de una cuestión que es esencial y exclusivamente religiosa (...) Erigiéndose en maestro dice que ni el rigorismo ni la más timorata convivencia autorizan a los párrocos para oponerse a que los casados sólo civilmente sean padrinos de bautismo (...) Un ministro librecultista dando lecciones de derecho canónico a los párrocos. ¿Dónde dice el derecho canónico que un casado civilmente puede ser padrino de bautismo? ...¿Dónde están los prelados de que habla? ¿Quiénes son esos doctores de la Iglesia que enseñan que los casados sólo civilmente pueden ser padrinos de bautismo? Si existen, ¿por qué no se citan? Si no existen, ¿por qué se inventan? (...) ¿Cómo se atreve el Gobierno a poner su mano sacrílega en una doctrina tan sagrada? El Gobierno tiene a su cargo la defensa de los derechos civiles. ¿Quién lo ha convertido en protector de los eclesiásticos? El derecho a ser padrino de bautismo no es civil, es pura y exclusivamente eclesiástico. Está fuera de la órbita del poder temporal (...) El padrino de bautismo es un fiador, hombre de confianza que exige la Iglesia para que tome sobre sí la responsabilidad de enseñar a ser buen católico al niño que se bautiza. ¿Puede inspirar confianza a la Iglesia, tratándose de un sacramento, el casado sólo civilmente que no quiere recibir otro sacramento?» Cf. B.E.O.M., 12-XII-1872, 292-295.

214. «En vista de la comunicación de V.E. dirigida a este ministerio con objeto de desvirtuar la queja producida contra el párroco de Benaocaz, el Rey ha tenido por conveniente resolver se esté a lo acordado». Cf. B.E.O.M., Ibid., 296.

215. «El consultor de párrocos, según aparece publicado en el boletín diocesano. Cf. Ibid., 296-300. «El obispo dice que el art. 21 de la Constitución garantiza la libertad de cultos y lo que el Gobierno dispone es opuesto a la libertad del culto católico. El ministro replica: estése a lo acordado. El obispo expone que el derecho canónico, según la legislación vigente, debe respetarse. $\mathrm{El}$ ministro dice: estése a lo acordado. El obispo dice: la Iglesia debe ser libre. El ministro se limita a decir: estése a lo acordado. Es decir, que para el ministro no hay más ley que su absurda R.O., aunque para sostenerla sea preciso infringir la Constitución y despreciar la libertad de conciencia (...) Si un ministro dicta una R.O. como la presente contraria a la ley fundamental, merece ser llevado a los tribunales de justicia para que lo castiguen por abuso de autoridad (...) Hay compasión para la persona del ministro y desprecio profundo hacia sus disposiciones cuando sean abusivas o ilegales. Esto no es despreciar la autoridad, es sólo hacer uso de los derechos individuales proclamados por el actual Gobierno para que los pueblos puedan libersrse de los abusos de los gobernantes». 
de buena fe, seducidos y engañados, creían que ya no tenían obligación de contraer matrimonio según el rito de la Iglesia» ${ }^{216}$.

El fin de la permisividad del matrimonio civil lo tenemos en la Restauración borbónica. El 22-I- y el 9-II-1875 se publican los decretos que tratan de ser medidas de «la política reparadora iniciada por el Gobierno», y el 19-II tuvo que hacerse pública una compleja instrucción de 29 artículos para ordenar el caos y clarificar la modificación que sufría el registro civil ${ }^{217}$. Inmediatamente el obispo malagueño se pone en contacto con los sacerdotes y diocesanos para comunicar los importantes documentos que ha hecho públicos el ministerio de Gracia y Justicia por orden del de Regencia ${ }^{218}$.

\section{Contenido doctrinal y pastoral}

Una vez más podemos comprobar cómo son los acontecimientos históricos - civiles y religiosos - los que marcan en gran medida la orientación que un prelado tiene que dar a la pastoral de su diócesis. Haciendo un cuadro sinóptico de los escritos pastorales de D. Esteban-José Pérez, de las fechas de publicación y de sus temas, podemos seguir al unísono los grandes acontecimientos que está protagonizando la España del sexenio y la cabeza de la Iglesia. Sin embargo, esto no obsta para que además se aprovechen ciertos hechos de especial transcendencia provincial o local para que el obispo ponga sus escritos y sus palabras al servicio del evangelio o que de esos grandes acontecimientos nacionales o internacionales se saquen orientaciones particulares para el clero y fieles de esta diócesis.

\section{Enseñanzas religiosas y morales al pueblo}

El tema del concilio era fuente de polémicas, recelos y esperanzas. El obispo malagueño trata de orientar a sus diocesanos sobre el significado religioso, trascendencia social y política en una carta pastoral ${ }^{219}$. Consideraba al futuro concilio como un fausto y venturoso acontecimiento que había hecho estremecer al mundo, que había revelado el temor de unos, el recelo de otros, el odio y la sorpresa en algunos, la enseñanza y el consuelo en todos los que confiaban en Dios. Por otra parte, era lógica y se esperaba oposición y guerra injusta e impía. Pronto daría principio el combate de la verdad contra el error,

216. Cf. Circular 157, B.E.O.M., 14-XI-1874, 209-219. Es una repetición casi literal de otras circulares -111 y 121 - que también trataban de estos temas.

217. Cf. B.E.O.M., 6-III-1875, 237-239; 242-247; 248-255.

218. Cf. Circular 163, B.E.O.M., 6-III-1875, 255-259. Prácticamente se reduce a derogar las circulares 121 y 157 y restablecer en toda su fuerza las disposiciones canónicas legales que regían antes de la publicación de la ley del matrimonio civil de 18-VI-1870 y exhortar a los párrocos a que colaboren con las autoridades civiles en la confección del registro civil.

219. B.E.O.M., 11-VIII-1869, 192-202. 
de la virtud contra el vicio, de la justicia contra la usurpación. Nadie podía considerar tranquilo el porvenir de su patria y del mundo viendo el empeño tenaz e insistente por destruir las verdades primarias y fundamentales de toda religión y de toda sociedad que era el programa de todos los enemigos del catolicismo ${ }^{220}$.

La sociedad necesitaba reformarse. Con tales doctrinas no podía vivir ni Europa ni el mundo sin que sobreviniese un gran cataclismo social. Insistía en que a pesar de todos los peligros y males, los concilios generales no eran absolutamente necesarios para custodiar el depósito de la fe y para regir y gobernar la Iglesia, porque no había cuestión grave e importante que el Pontífice romano no pudiese resolver con inapelable e infalible autoridad, pues cuando desde su cátedra sagrada pronunciaba un fallo, era decisivo, infalible e inapelable; pero en ciertas circunstancias, los concilios generales eran utilísimos ${ }^{221}$.

Poco antes de su partida a Roma, con el tema del concilio, escribe otra pastoral a sus diocesanos. Basándose en las palabras de S. Juan «No os dejaré huérfanos... voy y vengo a vosotros... voy al Padre» (Jn 14,18-28), explica los motivos de su viaje a Roma y les orienta para que permancezcan fieles durante la ausencia. Veía al materialismo y al ateísmo como algo que no podían engendrar más que el egoísmo en el orden económico, la muerte de toda libertad justa, la anarquía en lo político y social, la perturbación y ruina en la familia y la negación absoluta en lo religioso; veía al catolicismo como el antídoto que podía preservar del contagio de los que habían declarado la guerra a Dios y sólo en esta doctrina se encontraba la sociedad moderna segura para salvar aquella crisis angustiosa.

De lo primero que se deben cuidar y guardar es de la propaganda de la prensa, folletos o congresos internacionales obreros, porque con estos métodos lo que se intentaba era descatolizar al mundo predicando el materialismo, el racionalismo y sobre todo la incredulidad absoluta. Para conseguir estos fines no dudaban, según el obispo, en utilizar las mágicas palabras de ilustración, progreso, libertad, civilización... ya que con ellas entusiasmaban y seducían a los pueblos; además, era objetivo común de los enemigos de Dios

220. «Los congresos internacionales de obreros bien lo habían comprendido en estas aterradoras frases: 'guerra a Dios, a los gobiernos, al capital; odio a la clase media y a los capitalistas. La revolución es el triunfo del hombre contra Dios. Es preciso romper la bóveda del cielo como un techo de papel. Si a esto se opone la propiedad, es preciso aniquilarla; si se oponen cien mil cabezas, que caigan'». Ibid., 198.

221. Es revelador y significativo el hecho de que el obispo hable ya contundentemente de infalibilidad antes del concilio. Esto prueba la mentalidad del episcopado español que, ante los acontecimientos políticos del sexenio con la actitud antirreligiosa y anticlerical, hace que pase a una postura defensiva. La definición de la infalibilidad era un robustecimiento de la autoridad magisterial de la Iglesia en unos momentos en que el liberalismo español podía tender a una atomización del hecho religioso y. a un subjetivismo en su interpretación del magisterio y del valor de los signos religiosos. Cf. CUENCA TORIBIO, J.M., Estudios sobre la iglesia española del XIX. Rialp.-Madrid 1973, 26, 90-91. 
presentar al catolicismo como enemigo irreconciliable de esos derechos y prerrogativas a que aspiraba el hombre y la sociedad. Por último, esperaba que todos los diocesanos redoblarían sus cuidados y vigilancia para no dejarse seducir por las falsas doctrinas ${ }^{222}$.

Todavía antes de la partida aprovechará para escribir otra pastoral anunciando la institución en toda la diócesis del jubileo circular de las XL Horas. Del mismo modo que Jesucristo nos dejó en testamento la instịtución del sacramento de la Eucaristía, ahora él establecía el culto de esta devoción en su despedida para Roma y lo debían considerar como su testamento y último adiós antes de partir. Ve a este sacramento como el más augusto de todos, manantial de gracia e inefable misterio donde se realiza la unión de Dios y los hombres. Les avisa de que ahora que querían sorprenderlos con las doctrinas del protestantismo - que hablan de la eucaristía como de figura, señal...- es cuando debían testimoniar su creencia en la Presencia Real; después les presenta los efectos que se siguen de esa unión: en ella encuentran fuerzas los débiles, consuelo los afligidos, perdón e indulto los pecadores... se ilumina nuestro espíritu, se inflama nuestro corazón, se ennoblecen nuestras acciones, se diviniza nuestra vida. Deberían tener en cuenta a tres enemigos: a los poderosos que oprimían a Jesucristo con sus armas, a los sabios que le combatían con sus escritos, a sus propios hijos que le entristecían con sus pecados. Debían pedir a Dios por el papa, porque el concilio llegase a feliz término, por las necesidades de la Iglesia y por el Estado ${ }^{223}$.

Con motivo del primer aniversario de la implantación en la diócesis del jubileo de las Cuarenta horas, escribe una nueva pastoral, insistiendo en las razones hacía un año apuntadas. Recuerda los sufrimientos que en esos momentos padece el papa y aprovechando la proximidad del tiempo litúrgico de Adviento, hace una exhortación a prepararse cristianamente para recibir al Niño-Dios. Basándose en las palabras del apóstol S. Pablo a Tito $(2,12)$ «Renunciando a la impiedad y a las pasiones mundanas, vivamos con moderación, justicia y piedad en este mundo», saca unas conclusiones prácticas para los tres niveles donde se desarrolla la vida de todo cristiano: consigo mismo, con los hombres, con Dios ${ }^{224}$.

222. Cf. B.E.O.M., 17-XI-1869, 279-287.

223. Cf. B.E.O.M., 7-XII-1869, 295-303.

224. «Que viváis sobrios para con vosotros mismos. No os dejéis engañar por los profetas con falso nombre de amigos protectores, libertadores, salvadores, que buscan vuestro bien, independencia y felicidad, os dan en doradas copas el veneno de quitaros la religión (...) Que viváis de forma justa para con vuestro prójimo; sin perjudicarles en hecho, dicho o deseo (...) Que seáis piadosos para con Dios, porque los potentados de la tierra están persiguiendo a la Iglesia de Dios... a las armas de las potestades de la tierra oponed el arma de la oración, una vida ejemplar y unas costumbres edificantes». Cf. B.E.O.M., 4-XI-1870, 435-437.

225. Cf. Circular 122. B.E.O.M., 16-II-1871, 487-490. «Mandamos que en todas las parroquias de la diócesis durante la próxima cuaresma se tenga todos los domingos: manifiesto, estación, ro- 
La cuaresma ha sido, dentro de la vida litúrgica católica, uno de los tiempos fuertes para el cristiano y por la especial significación de la festividad a la que precede, ha sido un tiempo clásico para exhortaciones, cartas, ejercicios, sermones... y cualquier toma de contacto de los obispos con los fieles. Así vemos como monseñor Pérez Martínez aprovecha estar circunstancias para conseguir el contacto con sus diocesanos, aconsejarles y pedirles que no se hiciesen sordos en la próxima cuaresma, en este tiempo favorable y en esos días de salud, al llamamiento que de mil modos y maneras hacía Dios ${ }^{225}$. Otro año más tarde, por los mismos motivos, vuelve a escribir a sus diocesanos, exhortándoles a no llevar adelante el fuego del pecado, a no confundir la justicia con la iniquidad, a no llamarse cristianos y creyentes y hacer la guerra a Dios, a no confundir la fe y las enseñanzas propuestas por la Iglesia con la tiniebla del racionalismo y la falsa filosofía. Mediante la penitencia se puede separar esta mala semilla sembrada por el genio del mal y por el amor y la caridad responder a Jesucristo y como Joel $(2,12-13)$ se pueden volver a Dios con todo el corazón, por medio del ayuno, la oración y el llanto ${ }^{226}$.

\section{Formación teológica y pastoral al clero}

Casi en todos los escritos pastorales el obispo de Málaga no olvida a sus más inmediatos colaboradores, los sacerdotes, y siempre les dedica unas palabras que deben ser como la fuente de donde ellos sacarán unas normas prácticas para vivir más plenamente el ideal de su sacerdocio o unas orientaciones para que sepan encauzar más directamente a los fieles encomendados a su celo pastoral. El boletín eclesiástico de la diócesis está concebido como vehículo de permanente contacto del prelado con el clero, no solamente para las normas administrativas, sino para que tengan a disposición los documentos pontificios y dicasterios romanos, los del obispo y todos aquellos que se juzgan más importantes.

Monseñor Pérez Martínez poco tiempo después de haberse hecho cargo de la sede malacitana emprende una visita pastoral por algunos arciprestazgos de la diócesis, que es una ocasión inmejorable para tomar contacto real con los problemas religiosos y pastorales de la sede. Poco antes había publicado en el boletín una circular que, con el tema de la confirmación que debe administrar durante la visita pastoral, está plenamente dedicada al clero. Les recuerda que en sus catequesis deben insistir en que es un sacramento para crecer en la fe, que los padrinos deben ser los maestros de esa fe en el nuevo con-

sario, letanía y sermón. Los miércoles y viernes se tenga lo mismo y en defecto del sermón, una lectura espiritual de media hora, meditación sobre ella, terminándose con el rezo del viacrucis y cualquier otra devoción». Ibid., 489.

226. Cf. B.E.O.M., 27-I-1872, 647-652. Vuelve a citar textualmente las devociones que se realizarán en todas las Iglesias de la diócesis como en la circular 122. 
firmando. Así la confió Cristo a los apóstoles y a los obispos, sus sucesores y se recibe para estar firmes y ser fuertes ${ }^{227}$.

Hubo una época que los robos en las Iglesias de la diócesis malagueña se hicieron frecuentes. Generalmente los párrocos eran descuidados en la vigilancia de los templos, porque nunca se había atentado contra los objetos y bienes en ellos guardados. Ante esta oleada de robos, el obispo dicta normas prácticas para cuidar, vigilar y conservàr el tesoro sagrado y artístico que cada uno posea en las Iglesias a ellos asignadas. No conservarán nada en los templos que por su valor material o artístico pueda llamar la atención de estos hombres desaprensivos. Dado que la cosa fue relativamente frecuente, se llegó a hacer a los párrocos y encargados de las Iglesias responsables directos de lo que en ellas ocurriese ${ }^{228}$.

La retención por parte del Gobierno de la dotación asignada al culto durante tantos meses ocasionó un notable y agudo deterioro en utensilios y ornamentos litúrgiços, que en algunos casos llegó a ser preocupante ${ }^{229}$. El obispo se pone en contacto con su clero y traza un plan de urgencia para atender esta imperiosa necesidad, ya que en algunos casos estaba en juego la celebración de los sacramentos. Mandó hacer a tódos los párrocos un inventario de esos utensilios indispensables para celebrar los sacramentos, clasificándolos en buen uso, mediano o inservible, tratando de hacer y proveer lo que se pudiese ${ }^{230}$.

Antes de la partida al concilio tiene un intenso contacto con los diocesanos, como hemos visto. He aquí los consejos a los diferentes estamentos clericales: el cabildo catedral continuará dando ejemplo de paz, unión y fraternidad, por la pureza de costumbres y por la enseñanza de las verdades eternas; confía que el clero de la diócesis marchará delante por el camino de la virtud, alentando el espíritu de los débiles y fomentando la fe en los fuertes; los seminaristas confiaba que seguirían los consejos y enseñanzas del rector y catedrá-

227. Cf. Circular 60, B.E.O.M., 6-IV-1869, 79-81.

228. Las iglesias robadas fueron las de Comares, Macharaviaya, Cerro, Cagís, Pizarra, Churriana, Torre del Mar, Alcaucín, Benarrabá y las circulares escritas con este motivo: 69, 71 y 139. Cf. B.E.O.M., 19-V-1869, 113-114; 28-V-1869, 120; 2-IV-1873, 45-46, respectivamente.

229. Cf. Circulares 73, 78 y 136, B.E.O.M., 8-VI-1869, 133-134; 17-VII-1869, 177-178; 26IV-1872, 206-207.

230. Esto se hizo en dos ocasiones diferentes, dado que el cobro de la dotación del culto se retrasó durante años. Sin embargo, sólo de una de ellas hemos encontrado lo que el obispado sirvió a las diversaș iglesias de la diócesis:

- Casullas 17

-Frontales altar $\quad 3$

-Cíngulos

-Misales

-Amitos

-Paño de hombros

$\begin{array}{ll}\text {-Capas pluviales } & 5 \\ \text {-Albas } & 3 \\ \text {-Manteles altar } & 5 \\ \text {-Corporales } & 2 \\ \text {-Paño de púlpito } & 1\end{array}$

Cf. B.E.O.M., 17-VII-1869, 177-178. 
ticos de aquel centro y esperaba que las religiosas progresarían en la perfección, sirviendo de ejemplo a todos ${ }^{231}$.

Otro de los temas polémicos fue el de los cementerios y las secuelas de enterrar en sagrado o no, que traía a una sociedad como la española, cimentada en la normativa del catolicismo como religión oficial y única durante muchos siglos, o en ser la religión de prácticamente todos los españoles: unos, porque lo vivían de corazón; otros, porque en la muerte, como en el nacimiento o en la boda, la iglesia debía estar presente en sus vidas; de todas formas, fueron crueles y hasta trágicos en muchos casos los problemas que plantearon en la segunda mitad del siglo XIX cuando y como consecuencia de la libertad de cultos.

La instauración del registro civil trajo profunda desorientación en aquellas personas ignorantes que no se acostumbraron a pasar por dos lugares - juzgado y parroquia - para un mismo hecho - nacimiento, matrimonio y defunción.

Los obispos tienen que aconsejar, orientar y escriben circulares sobre este particular. El de Málaga clarifica así a sus sacerdotes el concepto de cementerio católico y los trámites eclesiásticos en caso de defunción: Los cementerios católicos son lugares consagrados considerados como un accesorio de las iglesias, por eso las disposiciones canónicas los constituían únicamente bajo la dependencia de la autoridad eclesiástica y la legislación civil sólo los había considerado bajo el punto de vista de la salubridad pública ${ }^{232}$. Los conflictos sobre esta materia nacían de la errónea creencia de tener por bastante la inscripción de la defunción en el registro civil sin cuidarse de sentar la partida en la parroquia correspondiente. Era preciso que las partes interesadas obtuviesen del párroco una papeleta que acreditaba que el finado había muerto en comunión con la Iglesia católica y para no contravenir el reglamento del registro civil, los párrocos no debían expedir la licencia de dar sepultura eclesiástica sin que antes le fuese presentada la del juez municipal. Por supuesto, los libros de defunciones se seguirían llevando en la forma de costumbre ${ }^{233}$.

Aprovecha la llegada de la cuaresma para dirigirse al clero tratando de cimentarles en razones teológicas y bíblicas, que es donde deben acudir en su reflexión y en su oración para que de esa continua meditación saquen frutos de vida eterna que puedan comunicarlos con provecho a las almas que tienen

231. B.E.O.M., 17-XI-1869, 286.

232. R.O. de 18-II-1861, sobre la conservación de las llaves del cementerio.

R.O. de 19-IV-1862, sobre autoridad en materia de cementerios.

R.O. de 6-X-1859, sobre sepultura eclesiástica.

Ley de 29-IV-1855, sobre enterramiento de los que mueren fuera de la comunión católica.

R.O. de 28-1I-1872, sobre la creación de otros cementerios para los réstos de los que mueren perteneciendo a religión distinta de la católica.

233. Cf. Circular 121, B.E.O.M., 4-II-1871, 480-481. 
confiadas. Inspirándose en el profeta Joel $(2,17)$ les aconseja: «Es preciso que vuestras palabras sean la trompeta que suene en la Sión de la Iglesia; que convoquéis a juntas en el templo del Señor, que congreguéis en él a vuestro pueblo para la oración; que purifiquéis a todos los pecadores; que hagáis llevar a los niños a fin de instruirlos en la doctrina cristiana» ${ }^{234}$. En otra carta pastoral con el mismo tema, repite literalmente la circular anterior haciendo notar a los sacerdotes que en ellos y en su actitud radica el resultado de la conversión de los fieles: «Debéis redoblar vuestros trabajos, vuestras vigilias y vuestro celo por la salvación de las almas y la reforma de las costumbres» ${ }^{235}$.

El matrimonio civil no sólo ocasionó problemas y protestas provenientes del terreno teológico-moral, sino fuertes complicaciones pastorales de adaptación y convivencia en el terreno práctico, que era donde y cuando había que demostrar lo que uno creía y cómo lo creía. Respecto al bautizo de los hijos de matrimonios civiles, en la partida se inscribirán como «hijos naturales», ya que la iglesia no reconoce canónicamente como legítimos a esta prole y así lo harán constar en la partida bautismal, poniendo que están desposados civilmente y no casados por la Iglesia ${ }^{236}$.

La formación permanente del clero fue una preocupación del obispo Pérez Martínez durante su pontificado. No basta adquirir conocimientos en la etapa de formación - seminario - sino que era preciso conservarla y acrecentarla añadiéndole la madurez y la experiencia del individuo. Con este fin se reinstauraron en la diócesis malagueña las llamadas conferencias morales; era obligatoria la asistencia a dichas conferencias, lo que supone la preparación y estudio de los temas y casos asignados para la exposición y discusión. También se podía sustituir por la asistencia a las clases impartidas en el seminario en la cátedra de teología moral. Para reiterar su importancia, la renovación de licencias y la colación de ciertos cargos, se hacía depender del puntual cumplimiento, asistencia y aprovechamiento a estas actividades ${ }^{237}$.

El tema del seminario era uno de los puntales básicos sobre el que se asentaba el futuro de la diócesis; allí estaban en alguna forma las raíces del edificio de la iglesia que era preciso cuidar en todos los aspectos. Malos tiempos los del sexenio por el ambiente reinante para que una vocación, que requiere sosiego, pueda seguir adelante. La libertad de enseñanza cargó nuevos impedimentos al no reconocer los estudios realizados en estos centros y desvincularlo de la universidad de Granada. La supresión de la dotación era otra dificultad, decisiva y casi insalvable, por la magnitud de la trascendencia.

234. Circular 122, B.E.O.M., 16-II-1871, 487-488.

235. B.E.O.M., 27-I-1872, 649.

236. Cf. Circulares 111 y 121 , B.E.O.M., 26-VIII-1870, 421; 4-II-1871, 486, respectivamente.

237. Cf. Circulares 89 y 136, B.E.O.M., 8-X-1869, 247-248; 23-X-1872, 278-279, respectivamente. 
El obispo Pérez Martínez siguió alentando la reforma iniciada por su antecesor monseñor Cascallana. Todos los años, casi con exactitud matemática, se repite el edicto en el que se fija la normativa que regirá en el seminario conciliar de S. Sebastián durante el curso académico. Se insiste en la presentación de un certificado del párroco donde conste la conducta y el uso frecuente de los sacramentos para seminaristas de años anteriores; los de nuevo ingreso presentarán el famoso certificado parroquial de «vita et moribus». Teniendo en cuenta las presentes circunstancias, el rector dispondrá las asignaturas en beneficio de los posibles alumnos que no sigan más adelante la carrera eclesiástica y así se puedan incorporar más fácilmente donde lo deseen. No se admitirán como alumnos externos a los que vivan en la ciudad de Málaga sin sus padres o familiares. Es causa de expulsión inmediata, para los alumnos externos, concurrir a los toros, bailes, teatros y cualquier otra diversión pública que desdiga del estado a que aspiran. La pensión económica por alimentación, asistencia médica, educación y residencia es de 2.000 reales ${ }^{238}$.

Otra muestra del interés que el seminario despertaba en el obispo malacitano es el hecho de que acogió la idea de crear en Roma un seminario español con total apoyo y entusiasmo. Allí podrían cursar estudios, bajo las garantías del mismo Vicario de Cristo y la dirección de los mejores profesores de las respectivas materias eclesiásticas del momento; además el beneficio que traería a la diócesis sería inmenso, porque estos jóvenes, ya sacerdotes, volverían a la diócesis con un cargamento de bienes científicos y espirituales, que revitalizarían el catolicismo entroncándolo directamente con el árbol milenario de la fecunda Madre Iglesia de Roma. Al inicio del curso académico 187677 se enviaron los dos alumnos que más habían destacado por conducta y aprovechamiento ${ }^{239}$.

El mismo estado angustioso de la falta de medios económicos de dotación hizo al prelado plantearse la posibilidad del cierre temporal del seminario; no se podía caer en esta tentación porque tener el seminario abierto era la única esperanza de sentir vivo el edificio religioso de la diócesis, en esos momentos críticos, tanto por la presencia de nuevos sacerdotes como por la certeza de que el mensaje del evangelio encontraba nuevos operarios para sembrarlo, difundirlo y cuidarlo en todos los rincones de la diócesis malacitana ${ }^{240}$.

238. Cf. B.E.O.M., 6-IX-1869, 224-226; 26-VIII-1870, 423-424; 25-VIII-1871, 579-581; 30 VIII-1872, 250-252; 14-IX-1874, 194-195.

239. Los gastos de los dos colegiales ascendían a 10.000 reales, demasiado cuantioso para una diócesis empobrecida por el atraso en la percepción de la dotación estatal. D. Carlos Larios Martínez, marqués de Guadiaro, se ofreció para subvencionar, en ayuda y bien de la diócesis, la mitad de estos gastos. Cf. Circular 189, B.E.O.M., 20-X-1876, 161.

240. Globalmente el acierto estribaba en haber logrado reducir, con sacrificio por parte de todos, los gastos al mínimo. Hasta que no se saliese de estos apuros impuso a los prebendados de oficio, la obligación de explicar gratuitamente una cátedra, igual que a algunos párrocos de la capital. Cf. Circulares 184 y 185, B.E.O.M., 7-IX-1876, 129-136; 15-IX-1876-136-140, respectivamente. 
3. Preconizado arzobispo de Tarragona. Dimisión y nuevo nombramiento para la sede malagueña

Los primeros meses de la República habían marcado una ascensión hacia la revolución permanente que le ganó la condena absoluta de los sectores derechistas y la retirada progresiva del apoyo de aquellos que creían posible, válido y viable, el sistema instaurado el 11 de febrero. La fiebre federalista y sus secuelas vinieron a desprestigiar todo cuanto en proclamas, 'manifiestos y declaraciones se había dicho meses antes. El cantonalismo tal y como se vivió y en los principios prácticos en los que se sustentaba era despedazar la España que tanto sudor, sangre y lágrimas había costado unificar. El error de antaño había sido hacer una única España; el de hogaño, era hacer tantas Españas que no había forma de reconocer en ninguna la mínima razón suficiente que sustentase una idea moderna de Estado.

Casi ninguno de los grandes problemas políticos que azotan la vida española del XIX tiene prolongación en lo eclesial. El regionalismo sólo presenta tonos suaves y desvaídos, en lo eclesiástico, en los años centrales del siglo y hasta varios decenios posteriores no adquiere tonos preocupantes ${ }^{241}$. Prueba evidente es que cuando en España privaba la corriente autonómica y cantonal, la Iglesia vivía tranquila.

Paradójicamente cuando sube peligrosamente la temperatura federal, el gobierno de Castelar se afana en arreglar los asuntos eclesiásticos con la S. Sede y traza un plan de remodelar cuatro sillas metropolitanas ${ }^{242}$. No estaban lejos de los deseos de virar a la derecha para ver si esto podía salvar al herido régimen republicano. Un acercamiento y entendimiento con la Iglesia era un apoyo nada despreciable. Y Castelar jugó la baza.

D. Esteban-José Pérez es designado pública y oficialmente para la diócesis metropolitana de Tarragona en el consistorio que celebró Pío IX el 16-I1874, consistorio suplementario que el Papa había acordado celebrar para llevar a término el acuerdo entre el bien espiritual de la Iglesia española, el Vaticano y el Estado español ${ }^{243}$. A Málaga llega inmediatamente la noticia de la

241. Cuenca Toribio, J.M., Sociología..., o.c., 179.

242. Dionisio Moreno Barrio, para Toledo; Miguel Payá Rico, de Cuenca a Compostela; Esteban-José Pérez, de Málaga a Tarragona y Félix M. ${ }^{a}$ de Arriete Llanos, de Cádiz a Valencia. Cf. Arch. Ministerio de Asuntos Exteriores, politica Santa Sede, leg. 2.673. En adelante citaremos Arch. M.A.E.

243. Este sistema de arreglo no podía fallar y era el cauce para entablar ese querido y deseado diálogo República-S. Sede. Confidencialmente se proponen los candidatos y se escogen, se presentan oficialmente por el Gobierno y el Pontífice los preconiza «motu proprio». El interés radicaba, según afirma el encargado de asuntos eclesiásticos en Roma, en «aprovechar la ocasión de no hallarse aún separado la Iglesia del Estado para el derecho de «presentación» y por lo pronto pueda proporcionar a la patria la inmensa ventaja de tener 27 prelados de confianza, o que por lo 
preconización de su obispo y la de Fray Ceferino González, de la orden de predicadores, para cubrir la vacante que se producía en Málaga ${ }^{244}$.

Pasan los meses y Málaga permanecía en un compás de espera para realizar el cambio de pastor por la negativa gubernamental a conceder el pase y renuncia del prelado saliente. El consistorio del 5-VII-1875 trataría de esclarecer toda la confusión al nombrar nuevamente como obispo de Málaga a monseñor Pérez Martínez ${ }^{245}$. Poco tiempo después, el 22 de noviembre, se dirige a los diocesanos malagueños para explicarles el largo proceso de los hechos. Aunque la fecha de la publicación de esta carta pastoral excede al cómputo señalado a nuestro estudio, por revertir sobre hechos acaecidos dentro del período, la incluimos y analizamos ${ }^{246}$.

Comienza reconociendo la sorpresa que le causó la noticia del nombramiento para Tarragona y el hecho de que en su interior surgió una lucha: la idea de la renuncia porque Málaga le había conquistado y la obligación de aceptar la nueva misión en la que se le requería. Venció, en un principio, la idea del deber y el papa expidió las bulas correspondientes a las que el Gobierno no concedió de momento el pase ${ }^{247}$. En este estado de cosas, es decir, con un nombramiento que no se hacía efectivo por impedimentos concordatarios, traería serias dudas sobre la competencia y jurisdicción de los obispos, que como él, habían sido trasladados a otras diócesis y a los que tampoco se les dejaba tomar posesión. El cardenal Antonelli, Secretario de Estado vaticano se apresuró a comunicar a los interesados una autorización expresa del Papa que les facultaba para seguir ejerciendo libremente su oficio en las respectivas diócesis de las que habían sido removidos ${ }^{248}$.

En estos días de tensión personal, los diocesanos y el clero malagueño se volcaron en oraciones y atenciones que ahora agradece, sobre todo, la peti-

menos no sẹan hostiles a la causa de la democraciai. Cf. Arch. M.A.E., política Sta. Sede, leg. 2.673 .

244. Arch. C.M., A.C., t. 71, 27-I-1874, 2v.-4.

245. B.E.O.M., 23-XI-1875, 326.

246. Cf. B.E.O.M., 23-XI-1875, 329-340.

247. La negativa del Gobierno estribaba en que no estaban formalizadas las relaciones diplomáticas de forma plena y con estas négativas quería presionar al Vaticano para que reconociese todos los derechos y privilegios que Roma había concedido a los diferentes reyes dice las dinastías hispanas. Bien explícito era en su informe el encargado español de asuntos eclesiásticos ante el Vaticano, al ministro de Estado, cuando le decía «tres son las principales dificultades que ocurren: primera, el no estar reconocido por Su Santidad el Patronato del Gobierno español para la provisión o nombramiento de las sedes vacantes. Patronato que nunca reconoció en el gobierno de D. Amadeo y que por lo tanto no reconocerá en el de la República...» Cf. Arch. M.A.E., política Sta. Sede, leg. 2.673.

248. Decisión que llega el 14 de abril, a través de monseñor E. Biachi, secretario del Nuncio ausente, Alejandro Franchi, y en estos momentos encargado de la custodia del archivo y del edificio de la nunciatura de Madrid, y a través del cual el Vaticano permanece enterado de las noticias que pueden afectar a la Sta. Sede. Arch. C.M., A.C., t. 71, 20-IV-1874, 10-10v. 
ción firmada por las corporaciones populares, clero y fieles que dirigieron al papa para que le confirmara nuevamente como obispo de Málaga. El 10-V1874, con la venia del Gobierno, firmó oficialmente la renuncia a la sede tarraconense y el propio secretario de cámara se trasladó a Roma a presentarla a Su Santidad para que la aceptase y lo confirmase en la sede malagueña.

Pío IX accedió a la petición y la ratificó por los decretos de la Sagrada Congregación Consistorial de 12 y 14 de octubre de $1874{ }^{249}$. Estando interrumpidas las relaciones Iglesia-Estado español, la preconización se había hecho por un acto de «motu proprio» del papa, en la esfera de su propia y peculiar competencia, y ahora por la misma autoridad, se dejaba sin efecto ${ }^{250}$, ya que única y exclusivamente compete al Romano Pontífice conferir la jurisdicción y la legítima misión a los pastores de la Iglesia católica; como consecuencia de ello, la validez y licitud canónicas que se derivaban de estos nombramientos eran legítimas, al margen de la opinión del gobierno de España.

Con la subida al trono de Alfonso XII estaba este problema resuelto de acuerdo con los cánones, pero pendiente de ratificar según el privilegio de los reyes de España. Por eso el monarca quiso ejercitar la prerrogativa de la corona -derecho de Patronato-y ratificar con arreglo a las leyes del país lo acordado por la Sta. Sede, en lo que hacía referencia al nuevo nombramiento para permanecer en la diócesis de Málaga ${ }^{251}$.

De cara a los fieles les dice con $\mathrm{S}$. Pablo «de buena gana daré lo mío y me daría a mí mismo por vuestras almas, aunque amandoos yo más sea amado menos» ( 2 Cor. 12,15), y está dispuesto a sacrificarse en aras del amor a sus diocesanos y por sus necesidades ${ }^{252}$. Los fieles deberán estar cada día más fir-

249. El $1 .^{\circ}$ de renuncia a la sede de Tarragona y el $2 .^{\circ}$ confirmándolo para la sede de Málaga, con el valor de Letras Apostólicas. Ibid., 20-X-1875, 42v.-49. Texto íntegro latino-castellano de ambos decretos en el B.E.O.M., 23-XI-1875, 332-335.

250. También se refiere a este aspecto el encargado español ante la S. Sede en su informe al ministro de Estado: «esta dificultad, aclara, refiriéndose a que el papa no reconocía el derecho de patronato al Gobierno de la República, puede superarse no haciendo mención en los breves de nombramiento, sino admitiendo como concedido de «motu proprio» por Pío IX. V.E. tendrá la bondad de manifestarme si esta claúsula podrá ser dificultad insuperable para el gobierno de la República, pues de ser así, el asunto es de todo punto imposible..." Arch. M.A.E., política Sta. Sede, leg. 2.673.

251. Según los trámites de costumbre, el Gobierno presentó a D. Esteban-José Pérez para la silla de Málaga y S. Santidad accediendo a los deseos de la Corona, lo preconizó oficialmente en el consistorio de 5-VII-1875, pasando de esta forma a ser un hecho concordado y conforme a los privilegios hispanos. El problema, pues, había sido únicamente referente a la forma y nunca afectó a la esencia del nombramiento y de las funciones que provenían de ese nombramiento. Esta confirmación dejaba como obispo titular a Fray Ceferino González. En el mismo consistorio fue preconizado obispo de Córdoba. B.E.O.M., 30-X-1875, 326.

252. «A distinguir al cabildo con marcadas pruebas de afecto, a conservar la deferente inteligencia y armonía con las autoridades, a inspirar máximas evangélicas en el clero, a mitigar el profundo dolor de las religiosas, a velar con particular esmero y solicitud por la enseñanza de los 
mes en la fe (Ef. 4,14) y así pide al Señor que los confirme en ella hasta el último momento de sus vidas. Pero hay que trabajar por conservar la fe que heredaron de sus padres, porque si es cierto que la fe no se impone por la fuerza, se propone y se persuade racionalmente y se debe proteger por las leyes, reconociendo y amparando sus derechos a reinar sola, negándolos al error, que no los tiene ni debe tenerlos. Motivo de ello es que así lo pide la conservación de la patria, la paz de la nación y la voluntad de la inmensa mayoría de los españoles ${ }^{253}$. Todo esto sería posible, según el prelado, para bien de la Iglesia y del Estado, y reinando Alfonso XII confiaba en que se tendrían en cuenta las justas peticiones de la Sta. Sede, del episcopado, del clero y fieles y las futuras Cortes restablecerían, como estaba pactado en el Concordato de 1851 , la unidad católica ${ }^{254}$.

\section{Sobre la masonería}

A principios de febrero de 1872 apareció un suelto en la prensa local, firmado por varios masones, en el que se vertían grandes y graves acusaciones contra los sacerdotes malagueños, sin probar ninguna de las serias acusaciones que allí se contenían. Aunque sin manifestarlo, era evidente que el ataque se dirigía al obispo como cabeza visible de la diócesis. Bajo el epígrafe de «quien a vosotros oye, a mí me oye; quien a vosotros desprecia, a mí me desprecia» (Lc 10,16), monseñor Pérez Martínez dirige una pastoral a todos los diocesanos. No es un escrito meditado, metódico y completo; tampoco lo eran las circunstancias. Urgía una toma de postura que fuese al mismo tiempo una respuesta ${ }^{255}$.

Parte del motivo supremo que es la obligación recibida de Jesucristo cuando les dijo a los apóstoles «Id y enseñad a todas las gentes» (Mt 28, 19-20). Según el prelado, en estas palabras se contiene el mandato exclusivo a la Iglesia y sus pastores de enseñar con magisterio infalible al cristiano. Otro motivo del escrito es el no dejar a su rebaño expuesto a la rapacidad de los

seminaristas, a cuidar del socorro de los pobres necesitados, a sostener y confirmar en la fe más y más a todos los diocesanos... y cuidar con mayor esmero y constancia de que se aparten de la herejía, del error y de la impiedad»; B.E.O.M., 23-XI-1875, 337.

253. Es clarividente que esta pastoral, estando escrita en días de la Restauración, vuelva a reproducir como argumentos válidos, los empleados en calendas anteriores al sexenio. Prueba manifiesta de que el episcopado no había aprendido - o no había querido aprender - la lección, por lo demás bastante clara, de los presupuestos, desarrollo y fines de la pasada revolución.

254. Prueba de que también por parte del Gobierno no se había aprendido nada del sexenio, salvo que era preferible ser amigo a enemigo del Vaticano, es aquella afirmación del ministro de Gracia y Justicia en la circular a los obispos y cabildos de 2 de enero, cuando les confesaba: «en las relaciones de los Estados católicos con la Iglesia, lo que para aquéllos es próspero suceso, para ésta no puede menos de ser feliz augurio de bienaventuranza». Arch. C.M., leg. 706, sin numerar.

255. Cf. B.E.O.M., 8-II-1872, 665-669. 
apóstoles del error; además, contaba con el apoyo total e incondicional del cabildo y párrocos de la ciudad a quienes había consultado sobre la oportunidad y conveniencia de esta publicación ${ }^{256}$.

Previene a los fieles para que no sean seducidos cuando les muestren los altos propósitos que afirma el art. 14 del estatuto general del Gran Oriente de las Dos Sicilias ${ }^{257}$. Para evitar todo acaloramiento directo que sería anticristiano, por poco evangélico, pone de manifiesto que no combatía a las personas, sino los errores, ya que como dice el texto sagrado, no quiere su perdición sino que se conviertan y vivan, porque su vocación y misión es la de amar a todos como hermanos e hijos de Dios.

La Iglesia, que no perdía de vista la salud de sus hijos, era la que había reprobado desde siempre a las sociedades secretas ${ }^{258}$ y los fines de las sociedades secretas conocidas por francmasonería y carbonarios eran principalmente propagar la indiferencia en materia de religión $\mathrm{y}$, más en concreto, a profanar la pasión del Salvador, despreciar los sacramentos de la Iglesia y los misterios de la religión católica.

Reduciéndose al tema de la masonería advierte el obispo sus consignas fatales: abajo la Iglesia y la autoridad, no más clérigos, no más Cristo, no más Dios, ya que el Dios que los masones veneraban con el nombre de Gran Arquitecto era un Dios que no existía y, lo que era peor, que los masones de las traslogias y los que poseían altos grados aborrecían hasta el nombre de Cristo. Por eso, aunque las logias alemanas habían hecho una declaración de confesión deísta, según el prelado, el deísmo en la práctica no era sino un ateísmo respetuoso y oculto y para ello le bastaba con recordar que los mejores escritores francmasones eran los que entonces estaban al frente del ateísmo y del materialismo ${ }^{259}$.

Mentían todos aquellos que para seducir y engañar, afirmaban que cada cual podía tener la religión que quisiera, ya que la masonería no era contraria al catolicismo y cualquiera podía ser buen católico y masón al mismo tiempo ${ }^{260}$. Tampoco los deberían creer cuando les dijesen que la masonería

256. Arch. C.M., A.C., t. 71, 1-II-1872, 5.

257. Ni cuando os digan «el fin de la institución es la perfección del hombre; que es indispensable que el libre masón practique la verdadera moral; que debe ser justo, humano, sincero, benéfico para con todo el mundo y, en particular, buen padre, buen hijo, buen hermano, buen esposo y buen ciudadano». B.E.O.M., 8-II-1872, 657.

258. Denzinger, E., El magisterio de la Iglesia (Manual de los símbolos, definiciones y declaraciones de la Iglesia en materia de fe y costumbres). Herder.- Barcelona 1963, n. ${ }^{\circ} 1697$, 1718a (pontificado de Pío IX). Posteriormente también n. ${ }^{\circ} 1859,1860$ y 1861 (pontificado de León XIII).

259. «Mundo Masónico», noviembre 1866.

260. «Es imposible ser al mismo tiempo francmasón y católico». «Mundo Masónico», mayo 1866. 
respetaba todas las creencias, religiones y cultos; era una impostura, una falsedad y una impiedad decir que la masonería era el cristianismo en toda su fuerza.

Clama lleno de amargura y dolor por una de las acusaciones que más le habían dolido y era la afirmación de que cuando los masones entraban en la Iglesia, en el altar veían la efigie de algún santo que había sido hermano de ellos ${ }^{261}$. Igualmente se siente indignado porque también afirmaban que la masonería contaba en su seno con insignes eclesiásticos por su ciencia y virtud. Por lo que de acusación podía tener contra su clero, sin excepción y en nombre de él, protestaba y rechazaba semejante ofensa ${ }^{262}$, ya que el obispo y el clero de Málaga estaban firmemente unidos a la Silla Apostólica y sabían las condenas que habian caído sobre las sociedades secretas ${ }^{263}$.

Como despedida recurre nuevamente al texto evangélico que citaba al principio - Lc 10,16 - para reafirmar su esperanza en que le escucharán porque eran buenos y conservarían intacta la fe porque amaban y veneraban a Pío IX ${ }^{264}$.

Pocos días después de publicada la carta pastoral, el cabildo remitió al obispo su adhesión por el mencionado escrito ${ }^{265}$.

En el periódico «El amigo del pueblo» del 7-III-1872, dentro del tema de la masonería, aventuraba una hipotética acusación de graves consecuencias,

261. «No es en los altares del verdadero Dios ni en los templos católicos donde ven los masones la efigie de un gran santo que ha sido hermano suyo; si lo ven será en los altares de Belial y Mahoma o en los altares de Lutero y de Calvino; y si ven los grandes santos, hermanos suyos, será en los altares de sus logias y en los altares de la incredulidad y del ateísmo, pero no en los católicos que son los altares del Dios verdadero" (B.E.O.M., 8-I1-1872, 665.

262. «Y como tenemos esa seguridad y convencimiento de que ninguno de nuestros sacerdotes es masón, notaréis que esta pastoral no va encabezada 'al clero' como todas las demás, sino a nuestros amados diocesanos». Ibid., 666.

263. Condenas de los Pontífices a las sociedades secretas y masonería:

\begin{tabular}{|c|c|c|}
\hline -Clemente XII & Bula «In eminenti» & $27-I V-1738$ \\
\hline -Benedicto XIV & Bula «Providas Romanorum» & $18-V-1751$ \\
\hline -Pío VII & Bula «Ecclesiam» & $13-1 X-1821$ \\
\hline -León XII & Bula «Quo Graviora». & $13-111-1825$ \\
\hline \multirow[t]{5}{*}{-Pío IX } & Encíclica «Qui pluribus» & 9-XII-1846 \\
\hline & Alocución «Quibus quantisque» & 20-IV-1849 \\
\hline & Encíclica «Noscitis et nobiscum» & 8-XII-1849 \\
\hline & Alocución «Singulari quidam» & 9-XII-1854 \\
\hline & Encíclica «Quanto conficiamur maerore» & 10-VIII-1863 \\
\hline & & \\
\hline -León XIII & Encíclica «Humanum genus» & 20-IV-1884 \\
\hline
\end{tabular}

DeZINGER, E., El magisterio de la Iglesia... o.c., 403, 405 y 434.

264. No era superfluo que aquí citase a la persona del papa, porque J.M. Ragón, en el ritual de grado de compañero había definido a Pío IX con las grotescas y bajas palabras de «el clerizonte más estúpido y atrasado». B.E.O.M., 8-II-1872, 667.

265. Arch. C.M., A.C., t. $71,10-\mathrm{II}-1872,5-5 \mathrm{v}$. 
cuando afirmaba que «el obispo se encuentra rodeado de sacerdotes masones, saluda a sacerdotes masones y vive en intimidad con sacerdotes masones». Las protestas no se hicieron esperar. Resumimos la carta enviada por todo el clero de la capital que, en cierto modo, era el más directamente aludido: «Protestamos pública y solemnemente contra la infundada calumnia, contra tan grave injuria, contra tan manifiesta falsedad y contra tan inmerecida mancha... que nunca hemos pertenecido ni pertenecemos a la masonería, sino que la condenamos, rechazamos y anatematizamos como lo han hecho los Pontífices... estamos identificados con la doctrina de la carta pastoral de nuestro obispo" ${ }^{266}$.

\section{Relaciones con Roma}

\section{El concilio Vaticano I y monseñor Pérez Martínez}

La convocatoria del concilio se presentaba para España teóricamente en momentos inmejorables: la perturbación e inestabilidad política hacía que los obispos fuesen apiñados en un haz para reivindicar los mismos objetivos; en la práctica, la provincialización de la política en las primeras semanas revolucionarias con sus extremismos y violencias y posteriormente las medidas abusivas del Gobierno Provisional, hacen que los obispos marchen a Roma absorbidos por sus propias dificultades político-religiosas y no se puedan entregar en alma y cuerpo a lo que pasaba únicamente en los pasillos y en el aula conciliar ${ }^{267}$.

Los meses anteriores a la apertura del concilio son de fecunda actividad pastoral en la diócesis malagueña. El boletín recoge puntualmente escritos oficiales y noticias cuyo objetivo es ambientar al clero, primer y casi único destinatario de esa publicación, pero a través de él, y de lo que la prensa civil está haciendo, el pueblo empieza a tomar conciencia del tema y es importante encauzarlo bien desde el principio. Durante el desarrollo de las sesiones conciliares la publicación diocesana mantiene la misma actitud, dando a conocér los decretos que van apareciendo y se van aprobando.

El motivo de la ida a Roma despierta en el obispo Pérez Martínez un elenco de objetivos, todos válidos, pero que demuestran que se encontraba bastante lejos de una actividad de estudios y profundización teológica, bíblica, moral o histórica ${ }^{268}$. No olvidemos que los veintiocho años que pasó de activi-

266. A continuación siguen las firmas de todos los sacerdotes de la ciudad. Cf. B.E.O.M., 13-III-1872, 178-181.

267. "Si hubiera de sintetizarse en un solo anhelo las aspiraciones de la jerarquía española que fue al concilio Vaticano I, había de escribirse esta sola palabra: autoridad». MARTin TEJEDOR, J., Los obispos españoles en el concilio Vaticano I, apéndice de Pío IX y su época, de R. Aubert. Edicep.- Valencia 1974.- 655.

268. Los motivos apuntados son: el encuentro personal con el papa, reanimar la fuerza y la 
dad parroquial en Loja le habían marcado y orientado hacia una actividad pastoral inequívoca ${ }^{269}$. El cabildo catedral, aprovechando el oficio de despedida le remite una carta en latín, fechada el día 13, para que la entregue personalmente al papa ${ }^{270}$.

El día 22-II-1870, dentro de la 29 congregación, cerrando el ciclo de los ponentes en el esquema del «Pequeño catecismo para toda la Iglesia», ocupó el ambón D. Esteban-José Pérez. El contenido de su exposición era como un corolario a lo que ya se había escuchado y pidió su aprobación ${ }^{271}$. Donde estuvo conciso, recogiendo el sentir de bastantes Padres, fue en el reproche de inoperancia que hacía al concilio. Lleno de desilusión afirmó: «Dos largos meses, casi tres, han pasado desde el comienzo de este santo concilio. Y iqué es lo que hemos realizado? Según la palabra de los apóstoles a su Maestro, hemos trabajado toda la noche y no hemos cogido nada. Después de tan numerosas congregaciones, de discusiones tan largas y extensas, todavía no hemos aprobado un solo esquema, ni un solo capítulo, ni un solo canon» ${ }^{272}$. Ya no volvió a tener más intervenciones y su presencia se limitó, como la de otros muchos prelados españoles, a votar los esquemas que se propusieron en la asamblea y engrosar la fila compacta del episcopado que se oponía a las tendencias antiinfalibilistas de la llamada «minoría». Después de la sesión solemne del 18-VII - votación de la Constitución «Pastor Aeternus»- por el calor del verano romano y la inminencia de la guerra franco-alemana, Pío IX había autorizado a los prelados, por causa justa, a ausentarse de Roma. Monseñor Pérez Martínez comunica al gobernador eclesiástico de Málaga que el día 27 de ese mismo mes espera estar de regreso ${ }^{273}$.

El recibimiento fue multitudinario porque a los eclesiásticos se le unieron los gobernadores, diputados provinciales, corporaciones y cofradías de la capital, además del ayuntamiento y gran número de vecinos de Antequera, así como el pueblo de Málaga que quería de verdad a su «venerable anciano» ${ }^{274}$.

virtud del ministerio en la fuente misma, cumplir con la visita «ad limina», la asistencia al concilio. B.E.O.M., 17-XI-1869, 297.

269. Este largo período que le hacía demasiado «viejo» para ser obispo es el único reparo que Roma oponía al deseo que Narváez tenía en proporcionarle una mitra a este amigo. MARTiN TE.JEDOR, J., Los obispos españoles..., o.c., 660.

270. Arch. C.M., M.C., t. 16, 18-XI-1869. Es bastante elocuente por sí misma: ... «Nos vestram Supremam Dignitatem, et excelsam Personam verbo, praedicatione et scripto defendere semper conamur, nefario impiorum hominum coetas, et doctrinas a populo fideli eradicare laborantes: in hac Eclesiae unitate nostram salutem sita credimus. Quidquid igitur Vestra Sanctitas probet, approbamus; quidquid damnet, condenamus». Ibid., 15-XI-1869.

271. Martín Tejedor, J., Los obispos españoles... o.c., 671.

272. AUBERT, R., Vaticano I.- Eset.- Vitoria 1970.- 151-152.

273. Arch. C.M., leg. 646, 85.

274. Arch. N.D. de E., leg. 192, carp. 2, 1. La noticia también se había publicado en el boletín eclesiástico, invitando a los católicos a elevar preces al cielo por el feliz regreso y a manifestar su gratitud en la llegada. Cf. Circular 107, B.E.O.M., 19-VII-1870, 403-404. 


\section{Sumisión al papa y la cuestión romana}

En el plano ideológico-religioso la diócesis de Málaga - como el resto de la España católica - se mantiene dentro de una exquisita fidelidad al Pontífice, manifestada y alentada de una forma especial en los años anteriores al sexenio, tras la euforia de la firma del Concordato y ante los primeros síntomas de preocupación por la actitud que el inquieto Gobierno italiano está dando muestras.

El año 1870 presenta para España un triple problema de complicada solución: la guerra franco-prusiana en la de que alguna forma ha tenido causa, la repercusión que este conflicto tiene en la cuestión romana y la candidatura para ocupar el trono de España que precisamente se ha puesto en un miembro de la casa de Saboya. No olvidemos que desde el 25 de septiembre de 1869, monseñor Franchi comunicaba de parte de su Gobíerno, que en adelante seguiría con el Gobierno de Madrid las relaciones oficiosas que conviene al actual estado de cosas. Y esta misma idea la repitió el Secretario de Estado Vaticano cuando recibió al nuevo embajador que enviaba España, Posada Herrera ${ }^{275}$.

Eń esta situación había transcurrido un año y para el Vaticano habían cambiado mucho las cosas; también en España. El gobierno de Madrid y el ministro de Estado, Sagasta, marca la pauta a los representantes españoles en Italia -Montemar en Florencia y Fernández en Roma-: equilibrio; hacer lo que los demás hagan respecto al Vaticano e intensificar las gestiones con el príncipe Amadeo. El 18-X el ministro de Asuntos Exteriores de Italia dirigía a todos los Gobiernos, a través de sus representantes en el extranjero, una circular en la que se garantizaba salvaguardar la independencia y la autoridad espiritual de la S. Sede. El 14-XI Sagasta contesta a la nota del Gobierno italiano a través del embajador en Madrid; es todo un tratado de diplomacia en el que se articulan los serios motivos que tiene España como católica, a los que no puede renunciar y los motivos con ese Gobierno al que le unen estrechos lazos de amistad ${ }^{276}$.

A nivel eclesiástico, España no cancelará en muchos años la cuestión romana porque se van sucediendo una serie de commemoraciones hábilmente

275. ArbeloA, V.M.-Martínez, A., Documentos diplomáticos sobre las relaciones Iglesia-Estado tras la revolución de septiembre de 1868. «Scriptorium Victoriense» (Vitoria), XX (1973), 198-232. El Vaticano, tan prudente y hermético, no quería sentar precedentes que luego podrían invocar otros gobiernos para obligar a la Sta. Sede a reconocer a quien no debiese o quisiese, según sus cálculos.

276. El Gobierno de Italia «ha de sacar incólume el poder espiritual del jefe de nuestra Sta. Religión de entre las ruinas del poder temporal de los Papas. En este resultado, España tiene más interés que ninguna otra de las potencias cristianas. La religión católica, que ella ha sido hasta ahora, de derecho, una de las bases de su existencia política y que hoy, aún después de establecida la libertad de cultos, es un hecho en la inmensa mayoría del pueblo español, le hace considerar como cosa propia todo lo que atañe a la suerte del Pontificado" Arch. M.A.E., Reino de Italia, correspondencia, leg. 1.615 . 
dirigidas a reavivar el recuerdo. La primera reacción de la diócesis de Málaga después de la llegada de Amadeo I, es la celebración de un solemne novenario a la Inmaculada por el estado angustioso del papa que será satisfecho por el obispo si los fieles no cubren los gastos con sus limosnas. En vista del éxito obtenido, para últimos del año - días 26,27 y 28 - se organiza un triduo con cuestación para pedir especialmente por el papa, a la vez que se le envía un donativo. El total recaudado ascendió a 26.000 reales de vellón ${ }^{277}$.

Como respuesta al último golpe de audacia del Gobierno piamontés que invade la ciudad de los papas, el obispo Pérez Martínez, el 21-XII-1870 dirige una circular a los diocesanos «poseído del mayor dolor y amargura al ver conculcados todos los derechos divinos y humanos y que el Vicario de Cristo se encuentra despojado de su principado civil y de la libertad e independencia necesarias para regir y gobernar la Iglesia» ${ }^{278}$. Se organiza una nueva y masiva recogida de firmas que se unirán a una carta de adhesión para ser enviadas a Roma. Pocos días después Pío IX contestaba al prelado, clero y pueblo de Málaga dando las gracias por el encendido afecto que le habían demostrado ${ }^{279}$.

\section{Bodas de Plata de Pío IX}

La Iglesia católica se preparaba para celebrar un gran acontecimento, al que dadas las circunstancias de tiempo, lugar y protagonistas, se preparaba apoteósico. Ni qué decir tiene que en España la celebración de las bodas de plata del pontificado del papa Mastai ocuparon febrilmente a clero, fieles y organismos piadosos durante semanas. El hecho ciertamente, no tenía precedentes: de los 257 predecesores de Pío IX ninguno había alcanzado la celebración de tal efemérides.

El obispo de Málaga ya había prevenido al cabildo del fausto acontecimiento. Poco después recibe una carta del Consejo superior de la Juventud Católica de España en la que se le pide que abra una suscripción para remediar las grandes necesidades de la Silla Apostólica. El obispo aprovecha esta oportunidad para solidarizarse con la proposición y recordar, a través del boletín eclesiástico, los últimos escritos que ha dirigido sobre este tema ${ }^{280}$. El ambiente era propicio para insistir sobre el tema y más cuando los hechos daban mo-

277. Cf. Circular 115, B.E.O.M., 5-XII-1870, 443-445. Arch. C.M., A.C., t. 70, 19-XII1870. Estos actos fueron ampliamente comentados y elogiados por la prensa local: El Correo de Andalucía, 29-XII-1870; Diario Mercantil, 31-XII-1870.

278. Circular 119, B.E.O.M., 28-I-1871, 471.

279. «Los sentimientos de acendrado amor que respiraba la carta remitida a Nos en nombre tuyo y en el de todo el pueblo de Málaga, interesaron profundamente a nuestro corazón. Nos hemos convencido de que ante el impío atentado cometido contra Nos y nuestra ciudad os afecta un dolor igual». B.E.O.M., 28-I-1871, 473.

280. Cf. B.E.O.M., 20-V-1871, 507-510. 
tivos. La ley de garantías acababa de ser votada; Pío IX había protestado en una encíclica ${ }^{281}$ y el prelado malagueño se siente en la necesidad de solidarizarse una vez más. En una circular vuelve a insistir en los argumentos pontificios de los que será fiel y cumplido expositor: «desventurados los que con impúdico cinismo o refinada hipocresía acometen la criminal empresa de despojar a la Silla Apostólica de los derechos que por providencia divina posee con los títulos más legítimos» ${ }^{282}$.

En la felicitación oficial que dirige el prelado en nombre de toda la diócesis están contenidos nuevamente todas las ideas que le llevan a la más fiel adhesión: despojado de sus posesiones, sometido a unas repugnantes garantías... y enumera los grandes acontecimientos de su prolongado pontificado: Inmaculada, Concilio Vaticano y canonización de los mártires de Japón. Para enjugar tanta tristeza y como prueba de amor filial le hace entrega de una ofrenda en metálico, valiosa para los malagueños que también están en apuros ${ }^{283}$.

Como preparación próxima a los acontecimientos, el 15 de junio dirige a los diocesanos una nueva circular agradeciendo las demostraciones de fe, religión y piedad en los actos de desagravio que se habían celebrado por el papa, la buena voluntad con se han ofrecido las limosnas para el donativo, por lo profundamente arraigada que tienen la religión católica...; al ayuntamiento, porque contribuirá a que haya procesión y verbena para solemnizar los actos y a los jefes y oficiales de todas las armas porque espontáneamente se han ofrecido a contribuir al esplendor de las fiestas ${ }^{284}$. Desde mediados de junio funcionaba una comisión que elaboró un complejo programa de festejos ${ }^{285}$.

281. Cf. B.E.O.M., 7-VI-1871, 519-526. El 15-V-1871 se votaba la ley de garantías que Pío IX rechazó constantemente en todas las intervenciones orales y escritas, porque sería reconocer el robo y porque eran unas garantías insuficientes ya que nadie las respaldaba y quedaba a merced de los futuros y continuos cambios de gobierno. Entonces comenzó la política del «non possumus» respecto a la renuncia de sus Estados y del «non expedit» respecto a la conducta de los católicos en la colaboración con el Gobierno de Italia. En la ley de garantías se declaraba que la persona del soberano Pontífice era inviolable y sagrada. Todo atentado contra él sería castigado con las mismas penas que los atentados contra la persona del rey. El Gobierno italiano tributaría al soberano Pontífice en el territorio italiano honores de soberano. Se reservaba en favor de la Sta. Sede una suma que rentase 3.225.000 liras. El soberano Pontífice gozaría de la posesión de los palacios del Vaticano, Letrán y Castelgandolfo, con todas sus pertenencias. Podría comunicarse libremente con todos los obispos del mundo y con todo el mundo católico sin injerencia alguna de parte del Gobierno. Se le reconocía el derecho de mantener nuncios en las naciones y de recibir embajadores ante la Sta. Sede. Los obispos de Italia serían nombrados por el papa; se retiraría el juramento de los obispos al rey y el placet y exequatur para toda publicación de carácter eclesiástico.

282. B.E.O.M., 7-VI-1871, 516.

283. Cf. B.E.O.M., 15-VI-1871, 527-530.

284. Cf. Circular 128, B.E.O.M., 15-VI-1871, 530-533. Y termina con un encendido elogio: «Nos tenemos por dichosos y felices apacentando una grey tan ilustrada, tan dócil, tan piador tan dispuesta a todo lo bueno».

285. Cf. B.E.O.M., 20-VI-1871, 540-542. Es curioso constatar, que en lo sustancial, este 
El número 100 del boletín eclesiástico se dedica monográficamente a relatar la crónica de la fiesta en la capital de la diócesis, deslumbrado el equipo de redacción porque durante unos días han hecho revivir brillantemente un cadáver, es decir, se empeñaron en montar toda una escenografía para representar el acto trágico de un papa-rey, al que se le quiere restituir inconscientemente en sus dominios temporales. Fueron días de teocracia, cuando la teocracia había pasado a ser un ente sólo válido para el estudio histórico de una determinada época ${ }^{286}$. También hay que apuntar una idea que queda manifiesta, tanto en la circular 128 como en las primeras líneas del $n .^{\circ} 100$ del boletín - ieditorial? - y es que se enfocó la celebración también para aglutinar a todos los católicos que por motivos sociales, políticos o culturales estaban desunidos ${ }^{287}$.

Varios periódicos de la ciudad siguieron informando y comentando los hechos que se sucedían en estos días. Amén de dedicar editoriales al tema, donde se repetían y ensalzaban los actos celebrados, porque externamente habían resultado multitudinarios y estéticamente bellos. Habían sido días eclesiásticos a nivel de sentimientos, sin calcular o presuponiendo lo religioso tras el aparato decorativo con que se montó esta celebración singular ${ }^{288 .}$

\section{F. Javier CAMPOS}

programa coincide con el de otras diócesis. Cf. Rodríguez de Coro, F., El obispado de Vitoria... o.c., 151-153.

286. Cf. B.E.O.M., 1-VII-1871, 543-558.

287. «...en el orden religioso no hay partidos, no hay diferencias, no hay opiniones, porque todos profesamos la misma doctrina y todos estamos unidos por el vínculo de una misma fe, una misma gracia y unos mismos sacramentos». B.E.O.M., 15-VI-1871, 531.

288. «Diario Mercantil», 25-VI-1871: Málaga y Pío IX. El Correo de Andalacía, 25-VI1871: Pío Nono y la católica Málaga. «El avisador malagueño» 25-VI-1871: Málaga y el catolicismo. 


\section{DIVISIÓN DE LA DIÓCESIS}

\begin{tabular}{|c|c|}
\hline Arciprestazgo & Pueblos que comprende \\
\hline ÁLORA & Imogía, Alozaina, Carratraca, Cártama, Casarabonela, Pizarra. \\
\hline ANTEQUERA & $\begin{array}{l}\text { Bobadilla, Humilladero, Mollina, Fuente Piedra, Valle de Abdalajís, Villa- } \\
\text { nueva de Cauche. }\end{array}$ \\
\hline ARCHIDONA & $\begin{array}{l}\text { Cuevas Bajas, Cuevas de San Marcos, Villanueva de Algaidas, Villanueva } \\
\text { del Rosario, Villanueva del Trabuco. }\end{array}$ \\
\hline COÍN & Alhaurín el Grande, Guaro, Monda, Tolox. \\
\hline COLMENAR & $\begin{array}{l}\text { Alfarnate, Alfarnatejo, Almáchar, Borge, Casabermeja, Comares, Cútar, } \\
\text { Periana, Riogordo, Viñuela. }\end{array}$ \\
\hline ESTEPONA & Casares, Genalguacil, Jubrique, Manilva, Pujerra. \\
\hline CAUCÍN & Algatocin, Benadalid, Benalhauría, Benarrabá, Jimena de Libar. \\
\hline GRAZALEMA & $\begin{array}{l}\text { Benaocaz, Benamahoma, Cortés de la Frontera, Bosque, Villaluenga del } \\
\text { Rosario. }\end{array}$ \\
\hline $\begin{array}{l}\text { MÁLAGA } \\
\text { (sin la capital) }\end{array}$ & $\begin{array}{l}\text { Alhaurín de la Torre, Benalgabón, Calà del Moral, Churriana, El Palo, } \\
\text { Moclinejo, Olías, Torremolinos, Totalán. }\end{array}$ \\
\hline MARBELLA & Benahavís, Benalmádena, Fuengirola, Istán, Mijas, Ojén. \\
\hline OLVERA & Alcalá del Valle, Setenil. \\
\hline RONDA & $\begin{array}{l}\text { Alpandeire, Arriate, Atajate, Benaoján, Burgo, Cartajima, Cuevas del Be- } \\
\text { cerro, Igualeja, Júzcar, Faraján, Montejaque, Parauta, Serrato, Yun- } \\
\text { quera. }\end{array}$ \\
\hline TORROX & $\begin{array}{l}\text { Algarrobo, Archez, Canillas de Albaida, Cómpeta, Corumbela, Frigiliana, } \\
\text { Maro, Nerja, Salares, Sayalonga, Sedella. }\end{array}$ \\
\hline VÉLEZ-MÁLAGA & $\begin{array}{l}\text { Alcaucín, Arenas, Benamargosa, Benamocarra, Benaque, Benajarafe, } \\
\text { Cagis, Canillas de Aceituno, Chilches, Daimalos, Iznate, Macharavialla, } \\
\text { Torre del Mar, Ventas de Zafarraya, Zafarraya. }\end{array}$ \\
\hline
\end{tabular}

\section{2 y 3.- PRESUPUESTOS DE CULTO Y CLERO DE LA DIÓCESIS}

Concepto

- Culto y clero catedral y otras atenciones

-Colegiatas suprimidas en el Concordato de 1851

-Parroquias y Beneficiados

- Seminario conciliar

-Administración de rentas eclesiásticas

-Religiosas pensionadas y otras atenciones

-TOTAL

- Líquido de bienes devueltos y Bula de la Cruzada

-Déficit que tiene que abonar el Estado
Año 1854

574.012 Rs.

72.480

1.447 .509

114.000

20.000

578.890

2.806 .891 Rs.

520.102

2.286.789 Rs. 


\begin{tabular}{lrrr} 
Concepto & Año $\mathbf{1 8 6 0}$ & Año $\mathbf{1 8 6 5}$ & \multicolumn{1}{c}{ Año 1868 } \\
\hline Personal del clero & 1.522 .123 & 1.617 .962 & 1.609 .020 \\
- Material & 694.021 & 720.354 & 690.361 \\
- Religiosas de clausura & 391.254 & 324.850 & 281.415 \\
- Material & 134.400 & 134.400 & 134.400 \\
- TOTAL, Rs. & 2.741 .798 & 2.797 .566 & 2.715 .196
\end{tabular}

\section{4.- PRESUPUESTO GENERAL DEL CULTO DE LA DiÓCESIS (Año 1853-54 y siguientes)}

- Vicaría de Málaga

32 Iglesias

14 "

12 "

- Vicaría de Antequera

- Vicaría de Archidona

- Vicaría de Ronda

- Vicaría de Olvera

- Vicaría de Marbella

— Vicaría de Vélez-Málaga

-TOTAL
$5 \gg$

46 i

$1 \%$

5 "

24 "

139 "
117.058 Rs.

54.540

38.102

13.661

100.482

6.982

18.794

64.972

$414.591 \mathrm{Rs}$.

\section{5.- DISTRIBUCIÓN DE PARROQUIAS}

\begin{tabular}{|c|c|c|c|c|c|}
\hline \multirow{2}{*}{$\frac{\text { Clase }}{\text {-de Término }}$} & \multirow{2}{*}{$\frac{1860}{42}$} & \multirow{2}{*}{$\frac{1865}{42}$} & \multirow{2}{*}{$\begin{array}{c}1868 \\
42\end{array}$} & \multicolumn{2}{|c|}{ Parroq. de capital: creadas en el año: } \\
\hline & & & & -Sagrario & $1488-1491$ \\
\hline - de Ascenso $2 .^{\circ}$ & 25 & 25 & 25 & -Santiago & $1490-1491$ \\
\hline - de Ascenso $1 .^{\circ}$ & 30 & 30 & 30 & —Stos. Mártires & $1490-1491$ \\
\hline —de Entrada & 25 & 25 & 25 & -San Juain & $?-1491$ \\
\hline -Rural, 1. ${ }^{\mathrm{a}}$ clase & - & - & - & —San Felipe Neri & $1481(?)$ \\
\hline - Rural, 2. ${ }^{\mathrm{a}}$ clase & 1 & 1 & 1 & -San Pablo & 1645 \\
\hline -Filiales & 11 & 12 & 12 & -San Pedro & 1658 \\
\hline -TOTAL & 134 & 135 & 135 & -N.S. de la Merced & 1835 \\
\hline & & & & -Sto. Domingo & 1841 \\
\hline
\end{tabular}

6. - ESTADO ECLESIÁSTICO DE LA DIÓCESIS, Según el Censo de 1860

\begin{tabular}{|c|c|c|c|c|}
\hline \multirow[t]{2}{*}{ Partidos } & \multirow[t]{2}{*}{ Clero } & \multirow{2}{*}{$\begin{array}{r}\text { Asintentes } \\
\text { al culto }\end{array}$} & \multicolumn{2}{|c|}{ Órdenes Religiosas } \\
\hline & & & Varones & Hembras \\
\hline ÁLORA & 38 & 24 & - & 16 \\
\hline ANTEQUERA & 77 & 39 & - & 136 \\
\hline ARCHIDONA & 35 & 16 & 10 & 30 \\
\hline CAMPILLOS & 29 & 62 & 1 & 3 \\
\hline COÍN & 38 & 29 & - & 14 \\
\hline COLMENAR & 30 & 28 & 2 & - \\
\hline
\end{tabular}




\section{Partidos}

\section{ESTEPONA}

GAUCÍN

MÁLAGA

MARBELLA

RONDA

TORROX

VÉLEZ-

MÁLAGA

TOTAL

ALBACETE

BARCELONA

\section{Clero}

16

42

206

23

51

30

53

688

267

2.184
Asintentes

al culto

9
24
93
18
54
17
64
477
200
594

Órdenes Religiosas Varones

Hembras

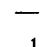

1

$6 \quad 308$

$\begin{array}{ll}- & - \\ 2 & 47\end{array}$

1

2

25

4

201
$-$

-

-

$-$

51

605

116

1.513

7.- DISTRIBUCIÓN DIOCESANA DEL CLERO

\begin{tabular}{|c|c|c|c|c|c|c|}
\hline \multirow[t]{2}{*}{ Clero } & \multirow[t]{2}{*}{ Cargo } & \multirow[t]{2}{*}{1860} & \multirow[t]{2}{*}{1865} & \multirow[t]{2}{*}{1868} & \multirow{2}{*}{$\begin{array}{r}\text { Año } \\
\text { Segorbe.-C. }\end{array}$} & \multirow{2}{*}{$\begin{array}{l}1868 \\
\text { Santiago }\end{array}$} \\
\hline & & & & & & \\
\hline \multirow[t]{4}{*}{ CATEDRAL } & Prelados & 1 & 1 & 1 & - & 1 \\
\hline & Dignidades & 5 & 5 & 5 & 5 & 6 \\
\hline & Canónigos & 15 & 15 & 15 & 11 & 20 \\
\hline & Beneficiados & 16 & 16 & 16 & 12 & 20 \\
\hline \multirow[t]{4}{*}{ COLEGIAL } & Capellanes & 8 & 20 & 20 & 7 & 20 \\
\hline & Abades y Canónigos & - & - & - & - & 11 \\
\hline & Beneficiados & 8 & 4 & 4 & - & 5 \\
\hline & Capellanes & 9 & 13 & - & - & 4 \\
\hline \multirow[t]{5}{*}{ PARROQUIAL } & Párrocos, Ecónomos & 119 & 131 & 147 & 63 & 794 \\
\hline & $\begin{array}{l}\text { Tenientes, Coadjut. } \\
\text { Regulares y Secular. }\end{array}$ & 113 & 223 & 160 & 33 & 133 \\
\hline & $\begin{array}{l}\text { adscritos a Parroq. } \\
\text { de la diócesis }\end{array}$ & 235 & 323 & 677 & - & 2.125 \\
\hline & $\begin{array}{l}\text { Exclaustrados sin } \\
\text { cargo pastoral en } \\
\text { la diócesis }\end{array}$ & 129 & 92 & 106 & - & 57 \\
\hline & Total Sacerdotes & 668 & 840 & 1.150 & 131 & 3.196 \\
\hline
\end{tabular}

\section{8.- SEMINARIO CONCILIAR DE SAN SEBASTIÁN}

\begin{tabular}{lrcc} 
& $\begin{array}{r}\text { Curso } \\
\mathbf{1 8 6 0 - 6 1}\end{array}$ & $\begin{array}{r}\text { Curso } \\
\mathbf{1 8 6 5 - 6 6}\end{array}$ & $\begin{array}{r}\text { Curso } \\
\mathbf{1 8 6 7 - 6 8}\end{array}$ \\
\hline Alumnos & 370 & 434 & 559 \\
Internos & 120 & 150 & 124 \\
Externos & 250 & 284 & 435 \\
Profesores & 8 & 12 & 12 \\
Títulos de Doctor & 2 & 5 & 2 \\
Títulos de Licenciado & 2 & 3 & 7
\end{tabular}

Dotación del Estado

90.000 Rs. 90.000 Rs. 90.000 Rs. 
9.- ORDENACIONES SAGRADAS (B.E.O.M.)

\begin{tabular}{rrrrrr}
\multicolumn{1}{c}{ N. } & \multicolumn{1}{c}{ Fecha } & Páginas & Sacerdotes & Diáconos & Subdiáconos \\
\hline 50 & $28-\mathrm{V}-69$ & $121-124$ & 24 & 10 & 13 \\
89 & $21-\mathrm{XII-70}$ & $461-462$ & 5 & 7 & 5 \\
96 & $20-\mathrm{V}-71$ & $512-513$ & 3 & 2 & 4 \\
111 & $17-1-72$ & $642-643$ & 2 & 8 & 8 \\
121 & $28-\mathrm{V}-72$ & $224-226$ & 8 & 7 & 6 \\
128 & $23-\mathrm{X}-72$ & $275-278$ & $?$ & $?$ & $?$ \\
139 & $13-\mathrm{VI}-73$ & $72-74$ & 8 & 7 & 6 \\
151 & $4-\mathrm{XI}-74$ & $201-204$ & $?$ & $?$ & $?$
\end{tabular}

\section{0. - CONVENTOS DE RELIGIOSAS EN LA DIÓCESIS}

\begin{tabular}{|c|c|c|c|}
\hline Ciudad & Orden Religiosa & $\begin{array}{c}\text { N. }{ }^{\circ} \text { de Monjas } \\
\text { año 1859-60 }\end{array}$ & $\begin{array}{l}\text { Contemplativas, se } \\
\text { dedicarán también a }\end{array}$ \\
\hline \multirow{9}{*}{ MÁLAGA } & Bernardas & 12 & Enseñanza \\
\hline & Cistercienses & 8 & Beneficencia \\
\hline & Dominicas Agust. & 16 & Enseñanza \\
\hline & Clarisas & 28 & Beneficencia \\
\hline & Benitas & 15 & Beneficencia \\
\hline & Sta. Teresa & 9 & Beneficencia \\
\hline & Dominicas & 7 & Beneficencia \\
\hline & Capuchinas & 14 & Beneficencia \\
\hline & Agustinas & & \\
\hline \multirow{6}{*}{ ANTEQUERA } & Agustinas Recol. & 13 & Beneficencia \\
\hline & Dominicas & 7 & Enseñanza \\
\hline & Mínimas & 8 & Beneficencia \\
\hline & Sta. Teresa & 4 & Beneficencia \\
\hline & Carmelitas & 9 & Beneficeǹcia \\
\hline & Dominicas & 16 & Enseñanza \\
\hline \multirow[t]{3}{*}{ RONDA } & Fcas. Clarisas & 11 & Beneficencia \\
\hline & Fcas. Descalzas & 10 & Enseñanza \\
\hline & Sta. Teresa & 6 & Beneficencia \\
\hline VÉLEZ-MÁLAGA & Fcas. Clarisas & 5 & Enseñanza \\
\hline ARCHIDONA & Fcas. Mínimas & 18 & Beneficencia \\
\hline
\end{tabular}

España tiene en esos momentos 866 conventos femeninos y 12.990 religiosas.

Cf. G.E.E., 1860, 948-949.

Cuadros estadísticos: fuentes

1. B.E.O.M., 21-X-1877, 160-163. G.E.E., 1860, 487; 1865, 374; 1868, 265.

2. G.E.E., 1854, 662-663.

3. G.E.E., 1860, 492-493; 1865, 376; 1868, 268. 
4. B.E.O.M., 5-VIII-1878, 222-254.

5. G.E.E., 1860, 908-909; 1865, 377; 1868, 269. B.E.O.M., 13-X-1872, 180-181. GUILI.EN

Robles, F., Historia de Málaga.., o.c., 507-510. Urbano, R., Guía de Málaga..., o.c., 48-78.

6. Saez Marín, J., Datos sobre la Iglesia..., o.c., 560 y 566.

7. G.E.E., $1860,934-935 ; 1865,659 ; 1868,683$.

8. G.E.E., $1860,488-489 ; 1865,374-375 ; 1868,267$.

9. B.E.O.M., en el gráfico quedan reseñados los números y páginas.

10. G.E.E., 1860, 490-491.

NOTA: En algunos casos — cuadros 6 y 7 - hemos incluido una de las diócesis de más y menos importancia númerica con relación al tema tratado, para mejor situar el valor y significación de la de Málaga. 